\title{
A revision of Nearctic species of the genus Geostiba Thomson, 1858 (Coleoptera: Staphylinidae: Aleocharinae)
}

\author{
VLADIMIR I. GUSAROV \\ Division of Entomology, Natural History Museum, University of Kansas, Lawrence, KS 66045-7523, U.S.A. \\ and \\ Department of Entomology, St. Petersburg State University, Universitetskaya nab., 7/9, St. Petersburg 199034, \\ Russia \\ vlad@ku.edu
}

\begin{abstract}
Nearctic species of the genus Geostiba Thomson, 1858 are revised. Redescription and illustrations are provided for distinguishing the genus Geostiba from other aleocharine genera. Six new species of Geostiba are described (G. (Sibiota) crepusculigena Gusarov, sp. n. from Tennessee, G. (S.) pluvigena Gusarov, sp. n. from North Carolina, G. (S.) coeligena Gusarov, sp. n. and G. (S.) nebuligena Gusarov, sp. n. from Tennessee and North Carolina, G. (S.) appalachigena Gusarov, sp. n. from West Virginia, Virginia, Maryland, Pennsylvania, New Jersey, New York, Massachusetts, Rhode Island, New Hampshire, Maine, Wisconsin and Québec; G. (S.) silvigena Gusarov, sp. n. from California). Nine species are redescribed (G. (S.) alticola Lohse \& Smetana, 1988, G. (S.) balsamensis Pace, 1997, G. (S.) bicarinata Lohse \& Smetana, 1988, G. (S.) graveyardensis Pace, 1997 and G. (S.) nubigena Lohse \& Smetana, 1988 known from North Carolina, G. (S.) carteriensis Pace, 1997 and G. (S.) nimbicola Lohse \& Smetana, 1988 known from Tennessee and North Carolina, G. (S.) impressula (Casey, 1906) known from Oregon, and G. (s. str.) circellaris (Gravenhorst, 1806) introduced from Europe to Newfoundland). A key for identification of Nearctic species of Geostiba is provided. Geostiba impressula (Casey, 1906) is removed from synonymy with G. circellaris. Ditroposipalia Scheerpeltz, 1951 is placed in synonymy with Sibiota Casey, 1906 (a valid subgenus of Geostiba), Geostiba fossata (Casey, 1910) with G. impressula (Casey, 1906), Sipaliella Casey, 1911 with Meotica Mulsant \& Rey, 1873 (a valid genus in tribe Oxypodini) and Sipalia (Sipaliella) filaria Casey, 1911 with Meotica pallens (Redtenbacher, 1849). Tylosipalia Scheerpeltz, 1951 is confirmed to be a synonym of Typhlusida Casey, 1906 (a valid subgenus of Geostiba). The lectotype of Sipalia fossata Casey, 1906 is designated. The geographical distribution of Geostiba in the Southern Appalachians is discussed.
\end{abstract}

Key words: Coleoptera, Staphylinidae, Aleocharinae, Geostiba, Sibiota, Ditroposipalia, Tylosipalia, Typhlusida, Sipaliella, Meotica, taxonomy, new species, synonymy, Nearctic, identification key, Southern Appalachians 
The genus Geostiba Thomson, 1858 (type species by monotypy: Aleochara circellaris Gravenhorst, 1806) includes about 300 Palaearctic species. In the Nearctic region nine species of Geostiba have been described and one introduced species has been reported up to now. Until 1975 many species of Geostiba were described in the genus Sipalia Mulsant \& Rey, 1853 (type species Homalota difformis Mulsant \& Rey, 1853, designated by Fauvel (1902a)), which is now considered to be a synonym of the genus Leptusa Kraatz, 1856.

Casey (1906, 1910, 1911, etc.) described more than one thousand species of aleocharines from North America. My study of his collection demonstrates that he often assigned species to incorrect genera (and sometimes incorrect tribes). That is why it was important to examine all of his types to exclude the possibility that any species of Geostiba were described in a different genus. Such examination confirmed the view expressed by Lohse and Smetana (1988) that only two species described by Casey belong to Geostiba: G. impressula (Casey, 1906) (originally placed in Sibiota Casey, 1906) and G. fossata (Casey, 1910) (originally placed in Sipalia), both described from Oregon.

Scheerpeltz (1951) divided Geostiba (as Sipalia) into fifteen subgenera based on different types of male secondary sexual characters.

Blackwelder (1952) designated Aleochara circellaris Gravenhorst, 1806 as the type species of the genus Evanystes Gistel, 1856 making Geostiba a junior objective synonym of Evanystes.

Seevers (1978) transferred eight species to Geostiba and Sipalia fossata to Sibiota.

Lohse and Smetana (1988) described four Southern Appalachian species of Geostiba and examined the types of the species placed by Seevers in several genera of the subtribe Geostibina Seevers, 1978. They transferred to different genera all eight species considered by Seevers as belonging to Geostiba, synonymized Sibiota with Geostiba and concluded that only two of Casey's species belong to Geostiba: G. impressula and G. fossata. Lohse and Smetana placed the first species in synonymy with G. circellaris (Gravenhorst, 1806), widespread in the Palaearctic region.

Pace (1997) described three additional species of Geostiba from the Southern Appalachians and assigned them to two subgenera known from the Palaearctic region.

While comparing the results obtained by Lohse and Smetana with those by Pace, I was intrigued by the geographical distribution of some species, for example, the relatively wide distribution of G. bicarinata Lohse \& Smetana, 1988 (reported from Clingmans Dome in the south to the Black Mountains in the north), and the sympatry of two extremely similar species, G. carteriensis Pace, 1997 and G. alticola Lohse \& Smetana, 1988 at Mount Mitchell. I also realized that the drawings of male genitalia in the two papers differ in style, making comparison and identification difficult. To resolve these problems several collecting trips to the Southern Appalachians were undertaken, and all seven known species and five undescribed species were collected. These specimens form the basis for the present revision. 
The holotypes and paratypes of the species described by Lohse and Smetana (deposited in CNCI) were examined. The holotypes of the species described by Pace are deposited in the Regional Museum of Natural Science in Turin (Museo Regionale di Scienze Naturali di Torino), Italy (Pace 1997). Pace did not indicate where the paratypes were deposited. Presumably they were split between Pace's personal collection and the personal collection of James F. Cornell (Charlotte, North Carolina, USA), who donated 10 paratypes of $G$. balsamensis Pace to North Carolina State University (http:// www.cals.ncsu.edu/entomology/Museum/Types/Staphylinidae.htm). The types of the Pace species were not examined but all three of his Geostiba species were collected at their type localities.

\section{Terminology}

In this paper I follow terminology accepted in aleocharine taxonomy (Sawada 1970, 1972; Benick \& Lohse 1974; Newton et al. 2000). The spermathecal gland is shown on the drawings solely to illustrate the gland position in relation to other parts of spermatheca. Terminology used to designate different parts of the internal sac of the aedeagus is discussed after the description of Geostiba. A few other points requiring clarification are discussed below.

Lateral and ventral sides of aedeagus. The orifice where the ejaculatory duct enters the aedeagus is here called the basal orifice. It is equivalent to the median foramen of Sharp and Muir (1912), orifice basal of Jeannel and Paulian (1944), basal orifice of Lindroth and Palmén (1970), and pore proximal of Coiffait (1972). The orifice through which the internal sac is everted is here called the apical orifice. It is equivalent to the median orifice of Sharp and Muir (1912), phallotreme of Snodgrass (1936), orifice apical of Jeannel and Paulian (1944), ostium of Lindroth and Palmén (1970), and pore distal of Coiffait (1972). Terminology by Sharp and Muir has priority but it is confusing as both orifices are called "median". I find it best to apply the words basal and apical.

The position of the aedeagus in the abdomen varies in different lineages of staphylinids. For example, in the subfamily Omaliinae the basal orifice of the aedeagus faces the dorsal side of the abdomen, while in Aleocharinae the basal orifice faces the ventral side. This difference is usually interpreted as a result of rotation of the aedeagus inside the abdomen. Not surprisingly, staphylinid researchers disagree on which side of the aedeagus should be called ventral and dorsal.

Sharp and Muir (1912) in their drawings document the different orientation of the basal orifice in the Staphylinidae, but do not discuss what caused it and do not mention rotation. They call the basal orifice side of the aedeagus ventral or dorsal, depending upon the orientation of the orifice in relation to the abdomen. For example, they refer to the side of the aedeagus with basal orifice as ventral in Gyrophaena (Aleocharinae) and Nicrophorus (Silphidae) and as dorsal in Stenus (Steninae) and Paederus (Paederinae). 
Blackwelder (1936) considers the side of the aedeagus with the basal orifice to be ventral in all illustrated staphylinids including, for example, Geodromicus (Omaliinae) and Creophilus (Staphylininae).

Jeannel and Paulian (1944) argue that in Staphylinoidea the aedeagus has rotated to different degrees and refer to the basal orifice side of the aedeagus as ventral in Silpha (Silphidae), Omalium (Omaliinae) and Ocypus (Staphylininae). They argue that the inversion of the aedeagus in Silpha and Nicrophorus is demonstrated by the position of tracheae which form a chiasm (the existence of this chiasm in Nicrophorus is confirmed by my dissection). They conclude that in Nicrophorus the aedeagus is rotated by $180^{\circ}$, claim that the same rotation took place in Staphylinidae and refer to the basal orifice side of aedeagus as ventral in all Staphylinidae. However, in Nicrophorus the basal orifice faces ventrally, the opposite of the orientation observed in Omaliinae.

The basal position of the basal orifice is considered to be a primitive condition in Coleoptera (Hansen 1997). In the basal Staphyliniformia this condition is retained (e.g., in Hydrophyloidea and Leiodidae), while in more derived Staphylinoidea (e.g., in Silphidae, Staphylinidae) the basal orifice is situated at the side of the aedeagus facing either ventrally (as in Nicrophorus (Silphidae), Aleocharinae) or dorsally (as in Omaliinae, Pseudopsinae). Within Staphylinidae it is the aedeagus that is subject to rotation to different degrees in many lineages, while the basal orifice is always situated on the homologous side of the aedeagus. It seems more convenient to call the homologous side of the aedeagus by the same name irrespective of the position of the aedeagus in the abdomen, rather than to change the name of the same homologous side in every lineage where the aedeagus is rotated. There is a long tradition of calling the basal orifice side of the aedeagus the ventral side (for example, Brundin 1944; Smetana 1971; Coiffait 1972). I follow this tradition and refer to the basal orifice side of the aedeagus as ventral, and the apical orifice side as dorsal. The words "ventral" and "dorsal" are used here to refer to a particular side of aedeagus, not to describe the position of the aedeagus in the abdomen, nor to imply that a particular position of the aedeagus is considered primitive or derived within Staphylinidae. The lateral view of the median lobe shows the right side of the aedeagus with the basal orifice facing right.

While illustrating the details of the aedeagus and abdominal segment 8 (but not 7) I place the posterior end of these parts at the top of the page. This orientation of the drawings is used in many works on athetine staphylinids (for example, Brundin 1944; Benick 1981; Muona 1983) and following this tradition makes comparison easier.

Measurements. Five males and five females of every species were measured (except in G. coeligena and G. silvigena known from fewer specimens). In most groups of staphylinids the abdomen can change length telescopically and thus affect the overall body length. The width of the pronotum is given in the descriptions as a more reliable indicator of specimen size. 
In Geostiba, as in many other aleocharines, the length of antennal articles 4-10 can be measured in different ways. These articles consist of the short and narrow basal stem and the main body of the article. The article body is more or less cylindrical but tapers off at the apex. The cylindrical part of the article is clearly delimited from the tapering part. The tapering part is easy to observe with a compound microscope, but hard to see in dry specimens because it is usually blocked by setae and by the next article. To make identification of dry specimens easier, only the cylindrical part of articles 4-10 is included in length measurements (Fig. 16).

\section{Depositories}

AMNH - American Museum of Natural History, New York (Dr. L.H.Herman)

CASC - California Academy of Sciences, San Francisco (Dr. D.H.Kavanaugh)

CNCI - Canadian National Collection, Ottawa (Dr. A.Smetana, Dr. A.Davies)

SPSU - Department of Entomology, St. Petersburg State University, St. Petersburg, Russia

FMNH - Field Museum of Natural History, Chicago (Dr. A.F.Newton)

KSEM - Snow Entomological Collection, University of Kansas

NMNH - National Museum of Natural History, Washington, DC (Dr. T.L.Erwin).

MZHF - Zoological Museum, Helsinki (Dr. J.Muona, Dr. H.Silfverberg)

\section{Geostiba Thomson, 1858 (Figs. 1-340)}

Evanystes Gistel, 1856: 387 (Type species: Aleochara circellaris Gravenhorst, 1806, by subsequent designation (Blackwelder 1952)).

Geostiba Thomson, 1858: 33 (Type species: Aleochara circellaris Gravenhorst, 1806, by monotypy).

Sipalia: Fenyes, 1920: 249 (non Mulsant \& Rey, 1853; non Fauvel, 1902a) (as valid genus in tribe Myrmedoniini Thomson, 1867).

Geostiba: Fenyes, 1920: 249 (as synonym of Sipalia).

Sonomota: Fenyes, 1920: 249 (as subgenus of Sipalia).

Sipalia: Bernhauer \& Scheerpeltz, 1926: 599 (as valid genus in subtribe Athetina Casey, 1910).

Geostiba: Bernhauer \& Scheerpeltz, 1926: 599 (as synonym of Sipalia).

Sonomota: Bernhauer \& Scheerpeltz, 1926: 599 (as subgenus of Sipalia).

Sipalia: Scheerpeltz, 1951: 166 (as valid genus).

Evanystes: Blackwelder, 1952: 163 (as valid genus).

Geostiba: Blackwelder, 1952: 163 (as synonym of Evanystes).

Geostiba: Benick \& Lohse, 1974: 111 (as valid genus in tribe Callicerini Lohse, 1969).

Geostiba: Seevers, 1978: 126 (as valid genus in subtribe Geostibina Seevers, 1978).

Evanystes: Seevers, 1978: 126 (as synonym of Geostiba).

Glossola: Seevers, 1978: 126 (non Fowler 1888) (as synonym of Geostiba).

Sonomota: Seevers, 1978: 128 (as subgenus of Geostiba).

Geostiba: Lohse \& Smetana, 1988: 270 (as valid genus).

Geostiba: Ashe in Newton, Thayer, Ashe \& Chandler, 2000: 371 (as valid genus in subtribe Geostibina). 
Evanystes: Ashe in Newton, Thayer, Ashe \& Chandler, 2000: 371 (as synonym of Geostiba). Glossola: Ashe in Newton, Thayer, Ashe \& Chandler, 2000: 371 (non Fowler 1888) (as synonym of Geostiba).

Sonomota: Ashe in Newton, Thayer, Ashe \& Chandler, 2000: 371 (as subgenus of Geostiba). (Other references for Palaearctic Geostiba are omitted)
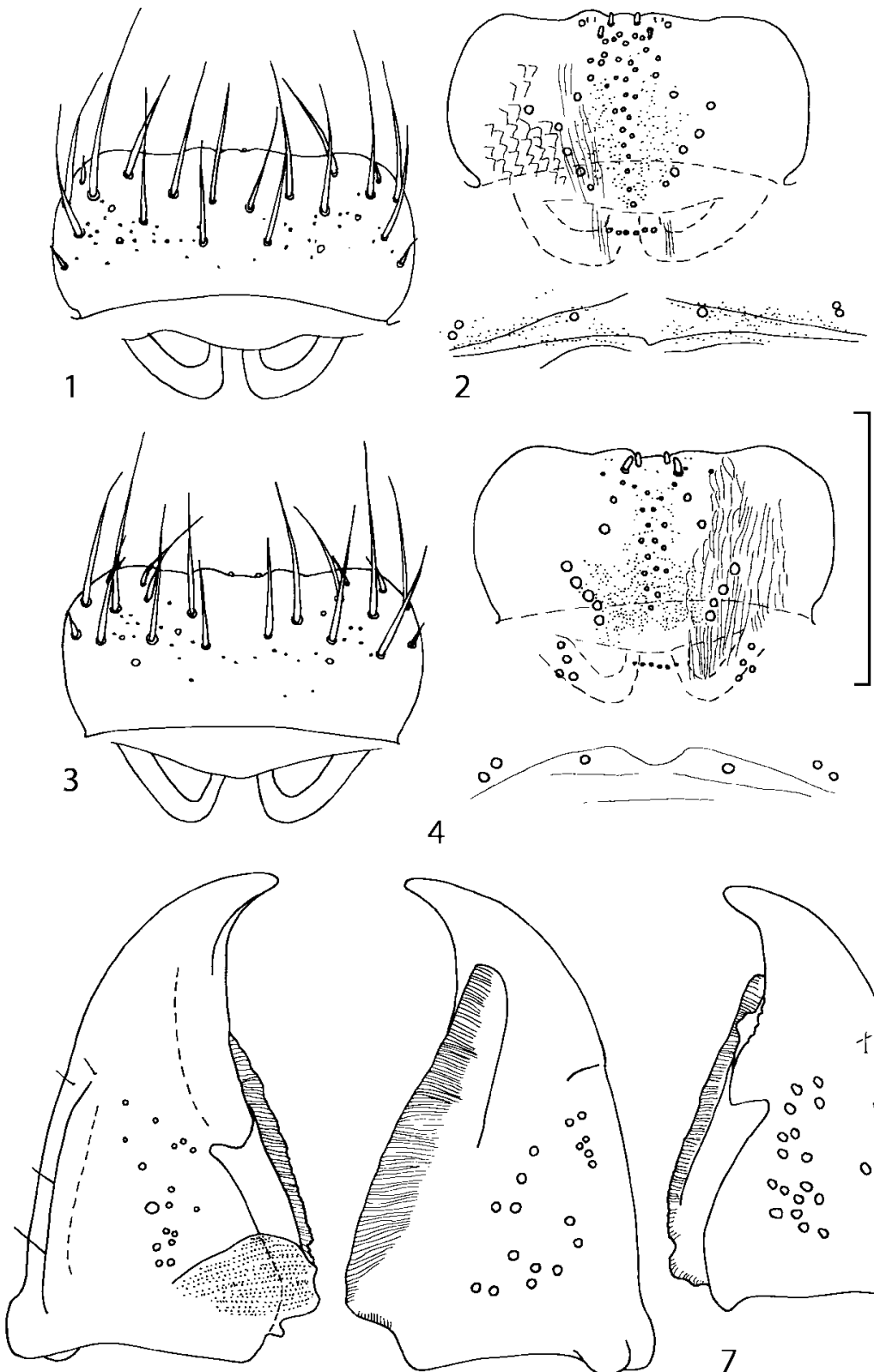

5
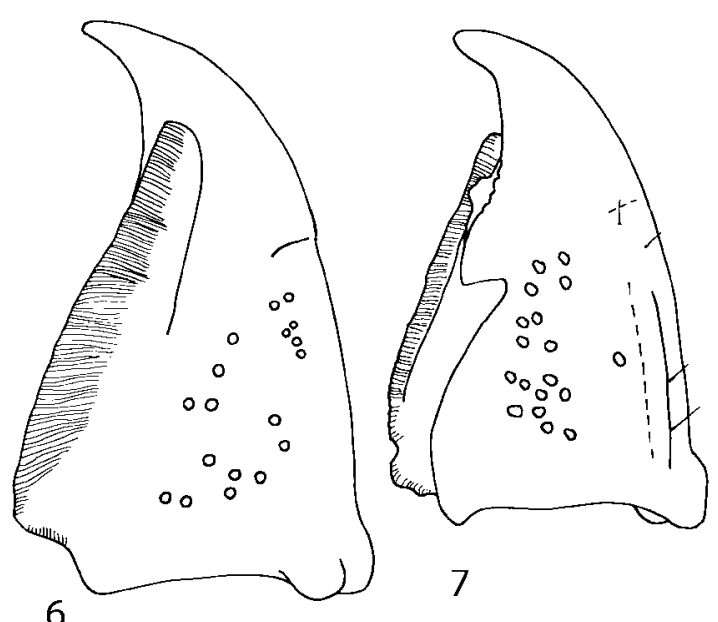

FIGURES 1-7. Mouthparts of Geostiba circellaris (Gravenhorst) (1-2, Moscow Region, Russia), G. carteriensis Pace (3-4, Tennessee), G. appalachigena Gusarov, sp. n. (5-6, paratype from West Virginia) and G. pluvigena Gusarov, sp. n. (7, paratype from North Carolina). 1, 3 - labrum; 2, 4 epipharynx; 5 - left mandible, dorsal view; 6 - left mandible, ventral view; 7 - right mandible, dorsal view. Scale bar $0.1 \mathrm{~mm}$. 


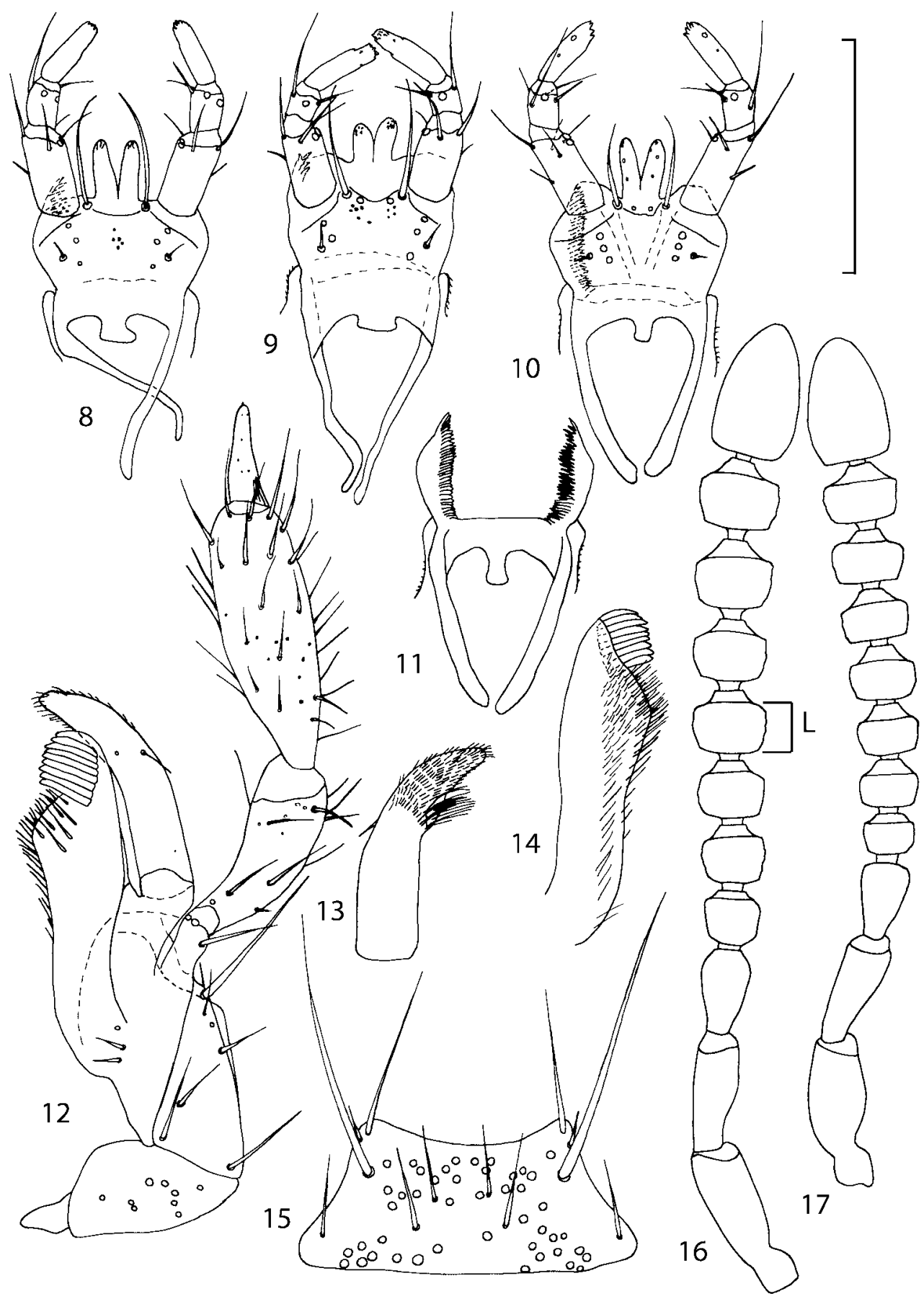

FIGURES 8-17. Mouthparts of Geostiba circellaris (Gravenhorst) (8, Moscow Region, Russia), G. infirma (Weise) (9, Ivano-Frankovsk Region, Ukraine), G. carteriensis Pace (10-15, Tennessee), G. appalachigena Gusarov, sp. n. (16, paratype from West Virginia) and G. pluvigena Gusarov, sp. n. (17, paratype from North Carolina). 8-10, - prementum; 11 - hypopharynx; 12 - left maxilla, ventral view; 13 - left galea, dorsal view; 14 - left lacinia, dorsal view; 15 - mentum; 16-17 - right antenna. Scale bar $0.1 \mathrm{~mm}(8-15), 0.2 \mathrm{~mm}$ (16-17). L - Length of antennal article. 
Diagnosis. Geostiba can be distinguished from other athetine genera by the combination of the following characters: parallel-sided body; ligula divided into two separate but close lobes (Figs. 8-10); pronotum with microsetae directed posteriorly along the midline of the disc (Type VI or V, Benick \& Lohse 1974) (Fig. 20); pronotal macrosetae short; pronotal hypomera fully visible in lateral view; mesotibia with short median macroseta; metatarsal segment 1 longer than segment 2; one empodial seta. Most species of Geostiba are wingless, have shortened elytra and reduced eyes.

Geostiba differs from the species of Atheta Thomson, 1858 with similar pronotal pubescence and short elytra in having the ligula divided into two separate lobes.

Geostiba differs from Tropimenelytron Pace, 1983 in having contiguous mesocoxae and the ligula divided into two separate lobes.

Geostiba differs from Alpinia Brundin, 1948 in having the ligula divided into two separate lobes.

Geostiba is similar to Ousipalia Gozis, 1886 in having the ligula divided into two separate lobes, but in Geostiba these lobes are contiguous while in Ousipalia they are widely separated.

Description. Length 1.7-3.2 mm. Body from dark brown to yellow, parallel-sided.

Head as wide as long; eyes $1 / 2$ to $1 / 10$ as long as temples or absent; infraorbital carina absent. Antennal article 2 longer than article 3, 4 subquadrate or transverse, 5-10 transverse, last article as long as 9 and 10 combined, without coeloconic sensilla (Figs. 16-17). Labrum (Figs. 1, 3) transverse, with straight anterior margin. Adoral surface of labrum (epipharynx) as in Figs. 2, 4. Mandibles (Figs. 5-7) symmetrical and broad, right mandible with a small medial tooth; ventral molar area without patches of denticles (400x). Maxilla (Figs. 12-14) with galea extending beyond apex of lacinia; apical lobe of galea covered with numerous fine and short setae; apical quarter of lacinia with row of closely spaced spines, middle portion produced medially and covered with numerous setae. Maxillary palpus as in Fig. 12. Labium as in Figs. 8-10, 15; labial palpi with three articles; ligula divided into two separate but close lobes; medial area of prementum with 1-2 pores and 010 pseudopores, lateral areas with 2-3 pores and single spinose pore. Hypopharyngeal lobes as in Fig. 11. Mentum (Fig. 15) with anterior margin concave.

Pronotum subquadrate or slightly transverse, broadest slightly in front of middle, sides broadly rounded; anterior margin convex; anterior and posterior angles rounded; posterior margin convex; surface covered with microsetae directed posteriorly in midline, posteriorly or obliquely posteriorly in lateral areas (Fig. 20) (Type VI or V, Benick \& Lohse 1974); macrosetae short; hypomera fully visible in lateral view. Posterior margin of elytra straight. In few species wings fully developed, in most species wings shorter than elytra or absent. Meso - metasternum as in Figs. 18-19, mesosternal process long and wide, extended about $1 / 2$ length of mesocoxal cavities, metasternal process short or not outlined (in wingless species), posterior margin of mesocoxal cavities complete or interrupted; mesocoxae contiguous. Mesotibia with short median macroseta (not longer than tibial 
width). Tarsal segmentation 4-5-5; metatarsal segment 1 longer than segment 2 . One empodial seta present.

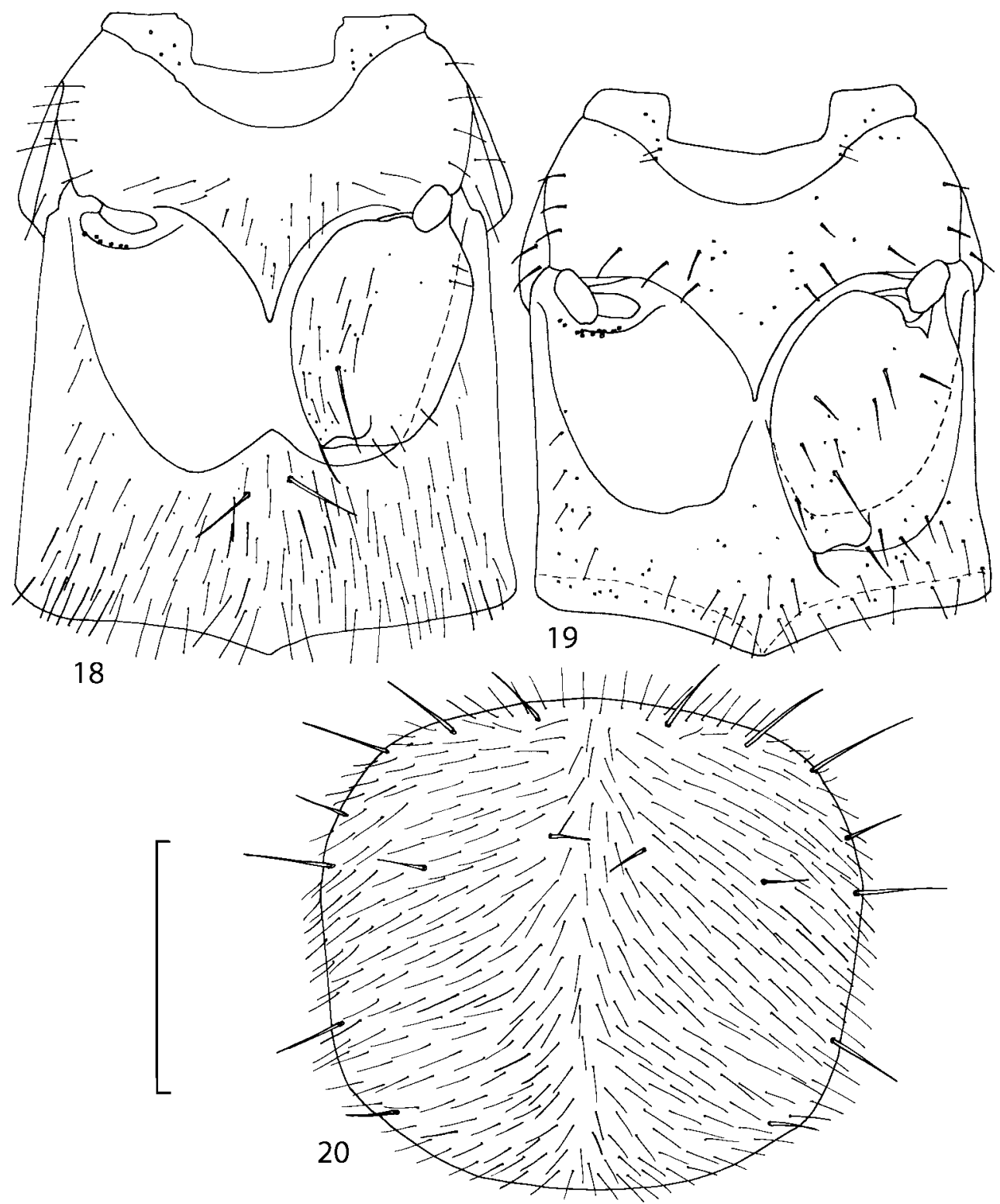

FIGURES 18-20. Thorax of Geostiba appalachigena Gusarov, sp. n. (18, 20, paratype from West Virginia) and G. carteriensis Pace (19, Tennessee). 18-19, - mesometathorax, ventral view; 20 pronotum. Scale bar $0.2 \mathrm{~mm}$.

Abdominal terga 3-5 with moderate transverse basal impressions. Tergum 7 1.2-1.3 times as long as tergum 6. Puncturation on terga 6-7 sparser than on terga 3-5. Female sternum 8 (Figs. 32-33) with row of apical microsetae (as in other Athetini). 
Male secondary characters absent or include some of the following: impression along pronotal midline, medial tubercle or extending lobe at posterior margin of pronotum, tubercle or carina near scutellum and/or impression on each elytron, 1-2 medial tubercles or carinae on tergum 7, tubercles or carinae on tergum 8.

Median lobe of aedeagus in ventral view narrows apically (Figs. 34-35, 57-58, 100101). Internal sac with 1-2 pairs of diverticula (Figs. 21-22, 24-28, 42, 64, 85, 112). Copulatory piece with narrow apical process (Figs. 23, 27, 39, 62). Medial lamellae narrow (Figs. 21-22, 24-28, 40, 47).

Synonyms. Gistel (1856) proposed the generic name Evanystes to include eight species but did not designate the type species or provide the description. For a long time the name Evanystes was ignored by staphylinid taxonomists who used the name Geostiba or Sipalia. The species included by Gistel in Evanystes made it a very broadly defined group, somewhat equivalent to Homalota of early staphylinid taxonomists. Blackwelder (1952) made a very unfortunate choice when he designated Aleochara circellaris as a type species of Evanystes. As a result the name Geostiba was made a junior objective synonym of Evanystes. To preserve the stability of nomenclature the majority of taxonomists working on the group continued to use the name Geostiba. Because Blackwelder (1952) and a few other entomologists used the name Evanystes as valid, the requirements of the Code (\$23.9.1, ICZN 1999) for preservation of Geostiba as a valid name are not met. An application to preserve the use of Geostiba and suppress the use of Evanystes has been submitted to the Commission on Zoological Nomenclature (Case 3239) by Gusarov.

Mulsant and Rey (1853) proposed Sipalia as a subgenus of Homalota Mannerheim, 1830, and included six species (three of them are now placed in Leptusa Kraatz, 1856, two in Geostiba, and one in Octavius Fauvel, 1873). Fauvel (1902a) validly designated Homalota difformis Mulsant \& Rey, 1853 as the type species of Sipalia Mulsant \& Rey, 1853. Because at that time Homalota difformis was already a member of Leptusa (Kraatz 1856; Bernhauer 1900), Sipalia replaced Leptusa (Fauvel 1902b). Evidently Fauvel's designation was overlooked by most workers. Leptusa continued to be used for the genus that included the type species of Sipalia (Bernhauer 1905; Reitter 1909; Bernhauer \& Scheerpeltz 1926; Scheerpeltz 1966, etc.) while Sipalia was used for Geostiba (Sainte-Claire Deville 1906; Reitter 1909; Bernhauer \& Scheerpeltz 1926; Scheerpeltz 1934; etc.). Lohse (1974) and Benick and Lohse (1974) brought attention to the synonymy of Sipalia and Leptusa and since then the name Geostiba was almost universally used as valid. A more detailed discussion of the name Sipalia can be found in the application to preserve the use of Leptusa and suppress the use of Sipalia, submitted to the Commission on Zoological Nomenclature (Case 3256) by Gusarov and Herman.

The generic name Glossola Fowler, 1888 is listed by Seevers (1978) and Newton et al. (2000) as a synonym of Geostiba. This is incorrect: Glossola should be listed as a synonym of the genus Aloconota Thomson, 1858 because the type species of Glossola (Homalota gregaria Erichson, 1839; by monotypy) is a synonym of the type species of Aloconota 
(Tachyusa immunita Erichson, 1840; by monotypy) which is regarded by Seevers (1978, p. $110)$ and Newton et al. (2000, p. 368) as a valid genus.

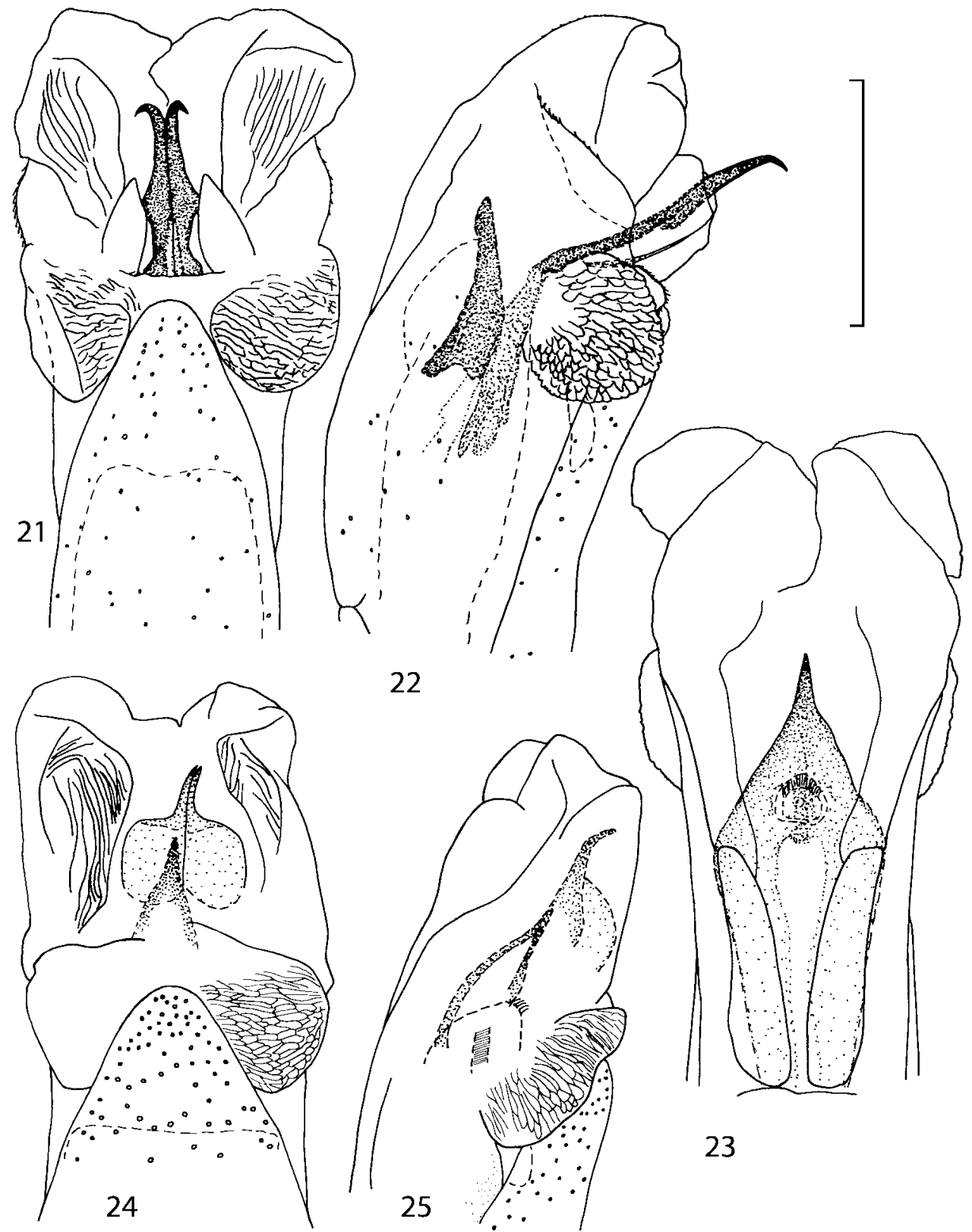

FIGURES 21-25. Partially everted internal sac of aedeagus of Geostiba circellaris (Gravenhorst) (21-23, St. Petersburg Region, Russia) and G. infirma (Weise) (24-25, Ivano-Frankovsk Region, Ukraine). 21, 24 - ventral view; 22, 25 - lateral view; 23 - dorsal view. Scale bar $0.1 \mathrm{~mm}$.

Lohse and Smetana (1988) placed the name Sonomota Casey, 1911 (described as a subgenus of Sipalia) in synonymy with Microdota Mulsant \& Rey, 1873, a subgenus of 
Atheta Thomson, 1858. This synonymy was overlooked by Newton et al. (2000) who list Sonomota as a subgenus of Geostiba. The type of Sipalia lippa Casey 1911 (the type species of Sonomota, by original designation) has the ligula divided into two lobes only at the apex as in other species of Atheta. Atheta lippa is similar to some other species of Atheta with short elytra (A. turpicula (Casey, 1910) described from Colorado, A. pacifica (Casey, 1910) from California and British Columbia, A. hesperica (Casey, 1910) from California and A. cornelli Pace, 1997 described from Oregon) and may represent a distinct lineage within Atheta. This group will be revised elsewhere.

Discussion. To find additional characters for species identification and to establish the relationships of Geostiba to the other genera of Athetini a special study of the internal sac of the aedeagus has been undertaken. The details of the internal sac of Nearctic species of Geostiba have not been illustrated adequately in published drawings (Lohse \& Smetana 1988; Pace 1997). The internal sac has been studied both in retracted and everted position in some Palaearctic species and in all Nearctic species described in this paper. Comparison of the details of the internal sac in Geostiba with those in some species of Atheta and Philhygra (Brundin 1944; Sawada 1972; Gusarov unpublished) demonstrates that in all three genera the internal sac has the same parts. The terms used by Brundin and Sawada can be applied to the homologous parts in the internal sac of Geostiba. The illustrations of the internal sac in retracted, partially and completely everted state show position of these parts (Figs. 197-202, 204-211).

To evert the internal sac, the aedeagus was placed in potassium hydroxide solution in which the soft tissue was partially dissolved. After that, the aedeagus was transferred into a drop of water. While the water was diffusing into the aedeagus it was often possible to evert the internal sac by gently pressing (dorsally) with an insect pin at the basal part of the median lobe. This apparently simulates the natural evertion of the internal sac during copulation when the muscles connecting the ventral and dorsal sides of the base of the aedeagus contract. To complete the evertion a thin but blunt minuten can be introduced inside the median lobe basally and then the partially everted internal sac can be pushed further out. After the internal sac has been everted, the aedeagus can be transferred back into potassium hydroxide solution for complete removal of soft tissue.

The copulatory piece (the term used by Sawada (1972); equivalent to the Ductuslamelle in Brundin (1944)) is the internal sac sclerite with the opening of ejaculatory duct in it (CP, Figs. 197-200, 206-207, 209-210). This sclerite is present in many tribes of the Aleocharinae, including the tribe Athetini. In Geostiba the copulatory piece narrows apically into a pointed process (Figs. 23, 39, 62). The suspensoria (the term used by Sawada (1972); equivalent to the S-förmigen Stäbe or hakenförmigen Bildungen of Brundin (1944)) are two structures connected laterally to the basis of the copulatory piece (S, Figs. 197, 199-200). In Geostiba the suspensoria are poorly sclerotized, with a group of tiny denticles at the apex. 
The medial lamellae (Mediallamellen of Brundin (1944)) are two sclerotized structures attached to the U-shaped plate (U-förmige Platte, Brundin 1944). When the sac is everted these structures are located on the ventral surface of the sac, proximal of the copulatory piece. In some groups of Athetini, the medial lamellae and the U-shaped plate are large and act to guide the copulatory piece while the internal sac is being everted. In Geostiba the medial lamellae are thin and narrow (ML, Figs. 197-198, 201, 208-210, 21-22, 24-28).

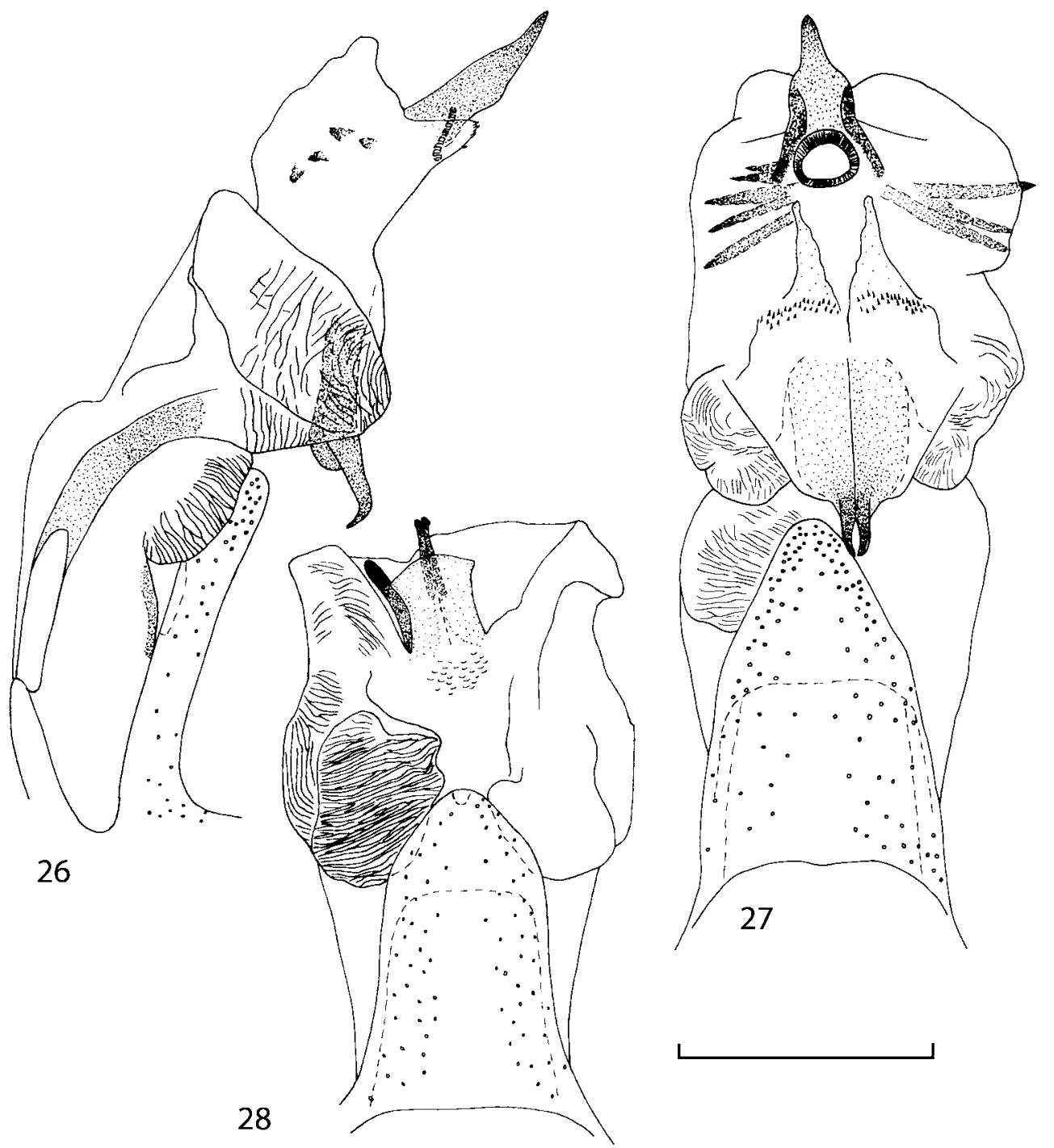

FIGURES 26-28. Partially everted internal sac of aedeagus of Geostiba padana (Weise) (26-27, Crissolo, Italy) and G. oertzeni (Eppelsheim) (28, Parnassos, Greece). 26 - lateral view; 27-28 ventral view. Scale bar $0.2 \mathrm{~mm}$. 
In Geostiba the ventral side of the everted internal sac proximal of the medial lamellae has one or two pairs of diverticula which may be an autapomorphy of the genus. In Palaearctic G. (s. str.) circellaris, G. (Sipalotricha) infirma (Weise, 1878), G. (Sibiota) padana (Weise, 1878) and G. (Sibiota) oertzeni (Eppelsheim, 1888) there is one pair (Figs. 21-22, 24-28), in all native Nearctic species of Geostiba there are two pairs of diverticula (DD, PD, Figs. 197-199, 202, 206, 210). The distal pair is more sclerotized than the proximal pair. A study of different Palaearctic lineages of Geostiba is required to confirm the presence of diverticula in all Geostiba and to establish homology between one of the two pairs of diverticula in the Nearctic species and the single pair in the few examined Palaearctic species.

While trying to evert the internal sac in different specimens of Geostiba, it was relatively easy to achieve what may be just a partially everted state. In this state, the lateral wall of the sac, which in many species has striate microsculpture (LW, Figs. 198, 209), forms a flange encircling the hollow from which the copulatory piece and medial lamellae protrude. When the internal sac is retracted into the median lobe, the striate lateral wall of the sac is clearly visible (LW, Figs. 204-205). Because the lateral wall is folded into three layers it often looks like a sclerite. This structure is shown schematically in some drawings by Lohse and Smetana (1988: Figs. 4, 12, 19, 26) and in one drawing by Pace (1997: Fig. 13). The shape of the folds and the microsculpture of the internal sac wall are stable within species and can be used for identification, although it is important to bear in mind that when internal sac starts to evert the position and the shape of the folds may change. In a few specimens I succeeded in everting the internal sac completely (Figs. 199, 210, 234, 242) and revealed the apical membranous portion of the sac which have tiny scattered denticles in some species. Additional study is necessary to determine whether the sac is completely or partially everted during copulation.

Some populations of Southern Appalachian Geostiba are very similar and it is difficult to decide whether they represent distinct species or forms of the same species. When two forms are sympatric and found in the same sample they are considered to represent different species. The situation with allopatric forms is more difficult. Even when a certain gap between two allopatric forms exists, additional consideration is needed to decide how to reflect this difference taxonomically. In this paper the difference between G. nimbicola and G. nebuligena is used as a criterion for assigning species rank to closely related allopatric forms. Both species are known from the Great Smoky Mountains massif and both were collected on Clingmans Dome, however never in the same sample or on the same date. The two species can be distinguished only by the shape of the apex of the median lobe of aedeagus (Figs. 100-107, 152-156). Whenever I encountered the gap on the same scale between two allopatric forms, I assigned to them species rank.

Some characters previously used in keys to distinguish species of Geostiba (Lohse \& Smetana 1988; Pace 1997) are found to be of limited utility. For example, the microsculpture of the abdominal tergum 7 is similar in all native Nearctic species. In the basal por- 
tion of the tergum the microsculpture consists of transverse meshes, while in the apical portion it consists of isodiametric or even elongate meshes (Figs. 56, 99, 125, 151, 192, 218). I did not count the number of ommatidia in the eyes but instead compared eye length to temple length.

\section{Key for Identification of Nearctic Species of Geostiba}

1 In males pronotum with one medial tubercle at posterior margin; each elytron with a tubercle near scutellum but not at the elytral suture; abdominal tergum 7 with one short medial carina in front of posterior margin. Posterior margin of female sternum 8 distinctly convex, without medial emargination. Aedeagus: Figs. 1-3 in Assing (2001). Spermatheca: Fig. 4 in Assing (2001). Body length 2.3-2.8 mm, pronotal width 0.43-0.53 mm. Introduced from Europe to Newfoundland (Fig. 336)

15. G. (s. str.) circellaris (Gravenhorst).

- In males pronotum without a medial tubercle at posterior margin; elytral suture is raised behind scutellum (flat in G. impressula); abdominal tergum 7 with two short and parallel medial carinae in front of posterior margin or without carinae. Posterior margin of female sternum 8 medially slightly concave or with emargination (Figs. 3233, 54-55). Native Nearctic species

2 Species occurring in eastern North America, east of the Rocky Mountains................. 3

- Species occurring in western North America, west of the Rocky Mountains ............. 15

3 Temples 2.3-2.7 times as long as eyes. Elytra (measured from humeral level) longer than pronotum. Wings fully developed. In males abdominal tergum 7 with two short and parallel medial carinae in front of posterior margin, abdominal tergum 8 with four short and weak carinae in front of posterior margin. Apex of median lobe in lateral view bent ventrally and widened apically (Figs. 36-37). Body length 1.9-2.4 mm, pronotal width $0.40-0.47 \mathrm{~mm}$. Widely distributed in eastern North America from Mount Rogers, Virginia in the south to Maine, Québec and Wisconsin in the north (Fig. 337) 1. G. (Sibiota) appalachigena Gusarov, sp. n.

- Temples 2.7-6.0 times as long as eyes. Elytra shorter than pronotum. Wings reduced to short vestiges, shorter than elytra. Apex of median lobe of aedeagus has different shape. Distributed in the Southern Appalachians (North Carolina and Tennessee) (Figs. 337-338)

4 Males (In males posterior margin of abdominal sternum 8 convex and without a fringe of wide setae (Fig. 30) and some species with two medial carinae on tergum 7) ....... 5

- Females (In females posterior margin of abdominal sternum 8 medially emarginate or concave, with a fringe of wide setae (Figs. 32-33, 54-55). Females never have carinae on abdominal terga 7-8). Females can be reliably identified only by association with males or by comparing locality data with known geographical distribution of different species of Geostiba. 
5 Abdominal tergum 7 with two short and parallel medial carinae in front of posterior margin, tergum 8 with four short and weak carinae in front of posterior margin ....... 6

- Abdominal terga 7 and 8 without carina or tubercles ............................................. 12

6 Body length 1.9-2.3 mm, pronotal width 0.40-0.46 mm. Antennal segment 4 slightly transverse (width to length ratio about 1.2; Fig. 16). Apex of median lobe in ventral view broad (Figs. 57-58, 77-78)

- Body length 1.6-2.3 mm, pronotal width 0.34-0.43 mm. Antennal segment 4 strongly transverse (width to length ratio about 1.6; Fig. 17). Apex of median lobe in ventral view narrow (Figs. 100-101, 126-127, 152-153) or broad (in G. balsamensis only, Figs. 193-194)

\section{8}

7 Apex of median lobe of aedeagus in lateral view not bent ventrally (Figs. 59-60). Body length 2.0-2.3 mm, pronotal width 0.40-0.46 mm. Known from the Great Balsam Mountains and Little Pisgah Mountain in the Southern Appalachians (Figs. 338, 340)

2. G. (Sibiota) bicarinata Lohse \& Smetana

- Median lobe of aedeagus in lateral view bent ventrally (Figs. 79-80). Body length 1.9$2.3 \mathrm{~mm}$, pronotal width 0.41-0.44 mm. Known from Graveyard Ridge and Black Balsam Knob in the Great Balsam Mountains - Pisgah Ridge massif in the Southern Appalachians (Figs. 338, 340) 3. G. (Sibiota) graveyardensis Pace

8 Apex of median lobe in ventral view broad (Figs. 193-194). Medial carinae on male tergum 7 weak. Body length 1.8-2.2 mm, pronotal width 0.36-0.39 mm. Known from the Plott Balsams - Cataloochee Divide massif in the Southern Appalachians (Figs. $338,340)$ 8. G. (Sibiota) balsamensis Pace

- Apex of median lobe in ventral view narrow (Figs. 100-101, 126-127, 152-153). Medial carinae on male tergum 7 strong

9 Apex of median lobe in lateral view with obtuse ventral projection (Figs. 176-177). Body length 1.8-2.3 mm, pronotal width 0.34-0.40 mm. Known from Snake Den Mountain in the Great Smoky Mountains massif (Figs. 338, 340)

..7. G. (Sibiota) crepusculigena Gusarov, sp. n.

- Apex of median lobe in lateral view without obtuse ventral projection (Figs. 102-103, 128-129, 155-156) 10

10 Apex of median lobe longer (Figs. 100-107), in ventral view the apex outline convex apically (Figs. 101, 105), in lateral view without denticle (Figs. 103, 107). Body length 1.6-2.0 mm, pronotal width 0.37-0.40 $\mathrm{mm}$. Known from many localities in the Great Smoky Mountains massif (Figs. 338, 340)

4. G. (Sibiota) nimbicola Lohse \& Smetana

- Apex of median lobe shorter (Figs. 126-133, 152-156), in ventral view the apex outline often doubly emarginate (Figs. 131, 153-154), in lateral view with a denticle (Figs. 128-129, 155-156) 11

11 Apex of median lobe in lateral view with a strong ventral denticle (Figs. 155-156), in ventral view the apex outline strongly doubly emarginate (Figs. 152-154). Body 
length $1.6-1.9 \mathrm{~mm}$, pronotal width $0.37-0.40 \mathrm{~mm}$. Known from many localities in the Great Smoky Mountains massif (Figs. 338, 340)

6. G. (Sibiota) nebuligena Gusarov, sp. n.

- Apex of median lobe in lateral view with a weak ventral denticle (Figs. 128-129), in ventral view the apex outline weakly doubly emarginate (Figs. 130-131) or convex (Figs. 126-127, 132-133). Body length 1.9-2.2 mm, pronotal width 0.36-0.43 mm. Known from the Plott Balsams - Cataloochee Divide massif in the Southern Appalachians (Figs. 338, 340)

5. G. (Sibiota) pluvigena Gusarov, sp. n.

12 Body length 1.8-2.2 mm, pronotal width $0.34-0.39 \mathrm{~mm}$. Lateral sides of the apex of median lobe with shallow emargination (in ventral view) (Figs. 219-220, 223-229, 249-250)

- Body length 1.9-2.6 mm, pronotal width 0.39-0.44 mm. Lateral sides of the apex of median lobe with deep emargination (in ventral view) (Figs. 267-268, 289-291) ..... 14

13 Median lobe of aedeagus in ventral view more narrow (Figs. 219-220, 223-229). Distal diverticula of internal sac long (Figs. 233-234), proximal diverticula small (Fig. 234). Body length 1.8-2.2 mm, pronotal width 0.34-0.39 mm. Known from the Great Balsam Mountains - Pisgah Ridge massif and from Standing Indian in the Blue Ridge in the Southern Appalachians (Figs. 338, 340)

9. G. (Sibiota) nubigena Lohse \& Smetana

- Median lobe of aedeagus in ventral view wider (Figs. 249-250). Distal diverticula of internal sac short and small (Figs. 253, 256), proximal diverticula very large (Figs. $253,257-258$ ). Body length 1.8-1.9 mm, pronotal width $0.34 \mathrm{~mm}$. Known only from the Great Smoky Mountains west of Clingmans Dome (Figs. 338, 340)

10. G. (Sibiota) coeligena Gusarov, sp. n.

14 Median lobe of aedeagus longer (Fig. 269), in lateral view more narrow (Figs. 269270), in ventral view the lateral sides of the apex less convex (Figs. 267-268). Body length 1.9-2.4 mm, pronotal width 0.39-0.44 mm. Known only from the Great Craggy Mountains and the Black Mountains in the Southern Appalachians (Figs. 338-339) ....

11. G. (Sibiota) alticola Lohse \& Smetana

- Median lobe of aedeagus shorter (Fig. 292), in lateral view broader (Figs. 292-293), in ventral view the lateral sides of the apex more convex (Figs. 289-291). Body length 2.2-2.6 mm, pronotal width 0.40-0.44 mm. Known only from Roan Mountain and the Big Bald (Bald Mountains) in the Southern Appalachians (Figs. 338-339)

12. G. (Sibiota) carteriensis Pace

15 Elytra (measured from humeral level) shorter than pronotum. Wings reduced, shorter than elytra. In males pronotum with strong, wide and deep impression along midline. Median lobe of aedeagus with wider apex (in ventral view) (Figs. 310-312, 315). Body length 2.2-2.7 mm, pronotal width 0.37-0.50 mm. Known from Oregon (Fig. 336) 13. G. (Sibiota) impressula (Casey)

- Elytra as long as pronotum. Wings fully developed. In males pronotum without deep 
impression along midline. Median lobe of aedeagus with more narrow apex (in ventral view (Figs. 323-324). Body length $2.4 \mathrm{~mm}$, pronotal width $0.41 \mathrm{~mm}$. Known from California (Fig. 336) ........................... 14. G. (Sibiota) silvigena Gusarov, sp. n.

\section{Subgenus Sibiota Casey, 1906}

Sibiota Casey, 1906: 350 (Type species: Sibiota impressula Casey, 1906, by original designation) (as a genus in tribe Bolitocharini Thomson, 1859).

Sibiota: Fenyes, 1920: 249 (as synonym of Sipalia Mulsant \& Rey, 1853).

Sibiota: Bernhauer \& Scheerpeltz, 1926: 599 (as synonym of Sipalia).

Ditroposipalia Scheerpeltz, 1951: 172 (Type species: Leptusa bidens Baudi, 1869, by original designation) (as subgenus of Sipalia), syn. nov.

Sibiota: Seevers, 1978: 128 (as valid genus in subtribe Geostibina Seevers, 1978).

Sibiota: Lohse \& Smetana, 1988: 270 (as synonym of Geostiba).

Sibiota: Ashe in Newton, Thayer, Ashe \& Chandler, 2000: 371 (as subgenus of Geostiba).

(other references for Palaearctic Ditroposipalia are omitted)

Diagnosis. Sibiota differs from other subgenera of Geostiba in having two longitudinal carinae in the middle of male abdominal tergum 7 in front of posterior margin.

Synonyms. Ditroposipalia is placed in synonymy with Sibiota because the type species of both have two longitudinal carinae on the male tergum 7 .

Discussion. Lohse and Smetana (1988) did not assign any of their four species to subgenera. Pace assigned his three species to subgenera Ditroposipalia (synonymized here with Sibiota) and Lioglutosipalia Scheerpeltz, 1951. The latter is now considered a synonym of Sipalotricha Scheerpeltz, 1931 (Assing 1999), which lacks modifications on male tergum 7.

The males of both western Nearctic species of Geostiba have male abdominal tergum with two carinae and are placed in the subgenus Sibiota (= Ditroposipalia). Eight of the twelve Appalachian species have male secondary characters corresponding to Sibiota and four species are consistent with Sipalotricha. However there are good reasons to believe that all sixteen native Nearctic species of Geostiba (that is, excluding G. circellaris introduced to Newfoundland) form a monophyletic group in relation to Palaearctic species of Sibiota (= Ditroposipalia) or Sipalotricha.

There are some characters shared by all native Nearctic species of Geostiba that may be autapomorphies for this group of species. These include: slightly raised elytral suture behind scutellum (except G. impressula); the proximal seta on the external side of paramere apex is the longest; internal sac of the aedeagus has two pairs of diverticula (Figs. 42, 48, 198, 210, 318), medial lamellae are short, narrow and bent ventrally (Figs. 40, 47, 201, 208). This form of the internal sac is very different from the forms found in Palaearctic G. (s. str.) circellaris (Figs. 21-22), G. (Sipalotricha) infirma (Figs. 24-25), G. (Sibiota) padana (Figs. 26-27) and G. (Sibiota) oertzeni (Fig. 28). The hypothesis of monophyly of the Nearctic group of species can be tested only if representatives from 
other lineages are included in the analysis, which is outside the scope of the present paper. However, if this hypothesis is accepted and both Sibiota and Sipalotricha are monophyletic groups, then all native Nearctic species must be placed in the same subgenus of Geostiba.

Among the twelve Appalachian species, G. appalachigena is the least adapted to cryptic habitats such as soil and leaf litter and has the following plesiomorphies: well developed wings, long elytra (longer than pronotum), large eyes (temple length / eye length ratio 2.3-2.7) and large body (pronotal width 0.40-0.47 mm). Geostiba appalachigena has well developed carinae on the male tergum 7 and could be considered a typical representative of the subgenus Sibiota. The four species of Geostiba without carinae can be considered as more adapted to cryptic habitats. In comparison to G. appalachigena they have the following apomorphies: reduced wings, short elytra (shorter than pronotum), small eyes (temple length / eye length ratio 3.8-6.0) and smaller body (pronotal width 0.34-0.44 $\mathrm{mm}$ ). One can hypothesize that the four species without carinae on male tergum 7 originated from an ancestor or ancestors with carinae. Two arguments confirm that this scenario is possible. Geostiba balsamensis, one of the smaller species (pronotal width 0.360.39), has weak enough carinae on tergum 7 that Pace (1997) overlooked them and placed this species in Lioglutosipalia. The state of the carinae in G. balsamensis can be considered intermediate between the well developed and the absent states. In many species of Geostiba the small males are known to lack secondary sexual characters present in the large males (Assing 2000). The same trend may take place when species evolve to a smaller size.

Taking into account the above arguments, I place all sixteen native Nearctic species of Geostiba in the subgenus Sibiota. This subgenus is also represented in the Palaearctic region from Europe to the Caucasus, Central Asia, Siberia and the Far East.

\section{Geostiba (Sibiota) appalachigena Gusarov, sp. n. (Figs. 29-50)}

Type material. Holotype, $o^{\star}$, UNITED STATES: West Virginia: Pocahontas Co., 19 km NEE Durbin, Hwy. 28, 38 36.65'N 79³7.78'W, 1250 m, forest litter, Picea, Fagus (V.I.Gusarov), 29.viii.2001 (KSEM).

Paratypes: UNITED STATES: West Virginia: Pocahontas Co.: 79 specimens, same data as the holotype (KSEM, AMNH, CNCI, SPSU, FMNH); $50^{x} 0^{x}$, 2 우, $9 \mathrm{~km} \mathrm{SW}$ Durbin, Forest Road 235, Back Allegheny Mt., 38²9.46'N 7953.85'W, $1430 \mathrm{~m}$, forest litter, Picea, Betula, Fagus (V.I.Gusarov), 30.viii.2001; 38 specimens, 11 km SW Durbin, Forest Road 235, Back Allegheny Mt., 38²8.46'N 7954.70'W, $1350 \mathrm{~m}$, forest litter, Betula, Fagus, Picea, Tsuga (V.I.Gusarov), 30.viii.2001; 4 specimens, 22 km SWW Cass, Hwy. 150, N slope of Red Spruce Knob, 38 $20.34^{\prime} \mathrm{N} 80^{\circ} 09.23^{\prime} \mathrm{W}, 1370 \mathrm{~m}$, forest litter, Fagus, Betula (V.I.Gusarov), 30.viii.2001; 30 specimens, 22 km SWW Cass, Hwy. 150, Black Mountain, $38^{\circ} 16.4^{\prime} \mathrm{N} 80^{\circ} 14.6^{\prime} \mathrm{W}, 1420 \mathrm{~m}$, in forest litter, Picea (V.I.Gusarov), 


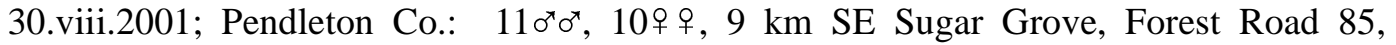
$38^{\circ} 28.1^{\prime} \mathrm{N} 79^{\circ} 14.1^{\prime} \mathrm{W}, 1250 \mathrm{~m}$, forest litter, Quercus, Acer, Tsuga, Betula (V.I.Gusarov), 29.viii.2001; $20^{\star} 0^{\star}, 9$ km SE Sugar Grove, County Road 25, 38 28.7'N 79¹3.4'W, $1170 \mathrm{~m}$, forest litter, Quercus, Acer, Tsuga, Betula (V.I.Gusarov), 29.viii.2001; 30 specimens, 18 km NWW Franklin, N slope of Spruce Knob, 3842.17'N 79³1.73'W, 1500 m, forest litter, Picea, Rhododendron, Acer (V.I.Gusarov), 29.viii.2001; o $\circ^{\star}, 3$ 우우, 19 km NWW Franklin, Forest Road 104, W slope of Spruce Knob, 3841.76'N 79³2.36'W, 1450 m, forest litter, Betula, Picea, Tsuga, Sorbus (V.I.Gusarov), 29.viii.2001 (all in KSEM and SPSU); $20^{\star} 0^{x}$, 우, Spruce Knob (Peck \& Barr), 26.viii.1964 (FMNH); Tucker Co.: 2우우, Davis near Blackwater River [3907.7'N 79²7.8'W], 900 m (L. \& N.Herman), 26.vii.1977 (AMNH); $0^{x}$, "Greenbrier Co., $21 \mathrm{~km}$ NE Richwood" [This label is not precise. The point $21 \mathrm{~km} \mathrm{NE}$ of Richwood is actually at the border between Webster and Pocahontas Counties, at least 11 kilometers from the border of Greenbrier County. It is impossible to give precise coordinates for this point] $\left[38^{\circ} 17^{\prime} \pm 05^{\prime} \mathrm{N} 80^{\circ} 25^{\prime} \pm 05^{\prime} \mathrm{W}\right.$ ] (A.Smetana), 13.v.1986 [This specimen bears Lohse's handwritten label "n. spec. ㅇ undescribed"] (CNCI); Virginia: Page Co. I Madison Co.: 10 specimens, 11 km SE Luray, Blue Ridge, below Old Man Mt. summit, $38^{\circ} 35.75^{\prime} \mathrm{N} 78^{\circ} 22.29^{\prime} \mathrm{W}, 1200 \mathrm{~m}$, forest litter, Picea, Quercus, Corylus, Abies (V.I.Gusa-

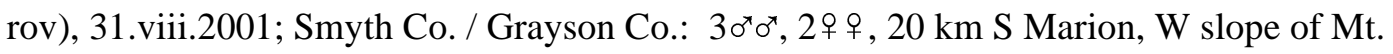

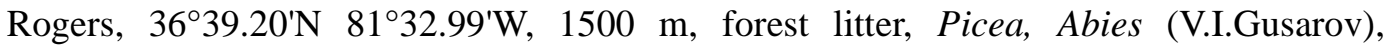

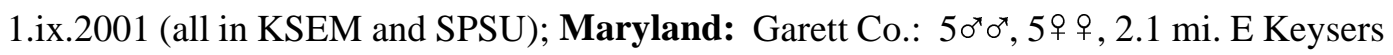
Ridge [3941.6'N 79¹2.6'W], 800 m (S.Peck), 18.vi.1968 (FMNH, KSEM, SPSU); Pennsylvania: Centre Co.: 67 specimens, 6 mi. SE Phillipsburg [4050.5'N 7808.0'W], 600 m (S.Peck), 17.vi.1968 (FMNH, KSEM, SPSU); Clinton Co.: 2우우 26 km SEE Lock Haven, $41^{\circ} 03.23^{\prime} \mathrm{N} 77^{\circ} 09.65^{\prime} \mathrm{W}, 350 \mathrm{~m}$, forest litter, Quercus, Tsuga, Pinus (V.I.Gusarov),

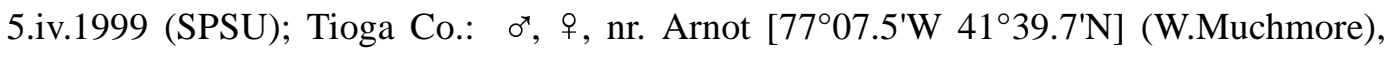

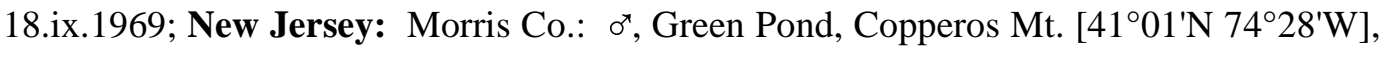
subcortical oak stump (W.Suter), 23.viii.1979; 우, ditto but 16.viii.1979; $0^{x}, 2$ 우 우, ditto but Green Pond, Pt. Comfort, 23.viii.1979 (all - FMNH); New York: Orange Co.: 6 speci-

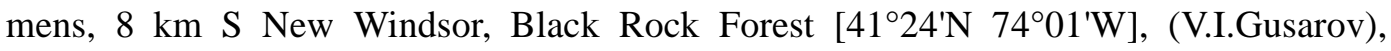
9.v.1998; 17 specimens, ditto but 23-25.v.1998 (all - SPSU); Ulster Co.: 55 specimens, 5 Mi. SSE Kerhonkson [41 $42.5^{\prime} \mathrm{N} 74^{\circ} 15.0^{\prime} \mathrm{W}$ ] (L.Herman), 30.iv.1977 (AMNH); Chataugua Co.: 3 웅, 2 mi. S Westfield $\left[42^{\circ} 17.4^{\prime} \mathrm{N} 79^{\circ} 34.3^{\prime} \mathrm{W}\right]$, leaf litter (L.E.Watrous),

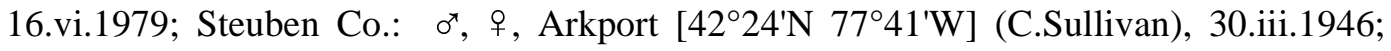
Albany Co.: $60^{\star} 0^{\star}, 6$ 우 우, Rensselaerville, Huyck Pres., Ravine near Lincoln Pd. [42 $31.7^{\prime} \mathrm{N}$

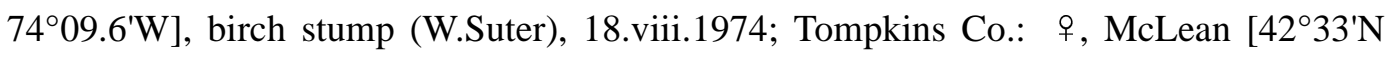
$\left.76^{\circ} 18^{\prime} \mathrm{W}\right], 17 . i v .1925$; Fulton Co.: $40^{\star} 0^{\star}, 2$ 우 92 mi. N Mayfield, shore of Sacandaga Re-

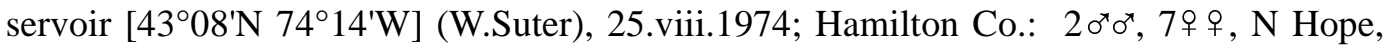
Hopefalls Rd. [ $43^{\circ} 18^{\prime} \mathrm{N} 74^{\circ} 14^{\prime} \mathrm{W}$ ], along rocky stream (W.Suter), 25.viii.1974; Massachu-

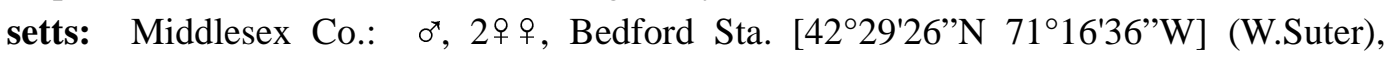

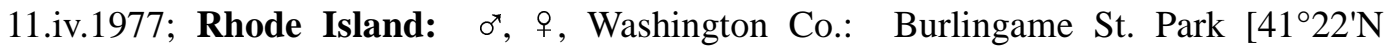


71 ${ }^{\circ} 42^{\prime}$ W] (L.E.Watrous), 30.xii.1975; New Hampshire: Grafton Co.: $20^{\star} 0^{x}$, Zealand R., 6 mi. SE Twin Mt. [ $44^{\circ} 13^{\prime} \mathrm{N} 71^{\circ} 29^{\prime} \mathrm{W}$ ], $700 \mathrm{~m}$, fir - spruce - birch forest, berlesing litter (A.Newton \& M.Thayer), 5.ix.1975; Carroll Co.: $0^{\star}$, 4우우, Ossipee Alspine Cpgd., Rt. 16

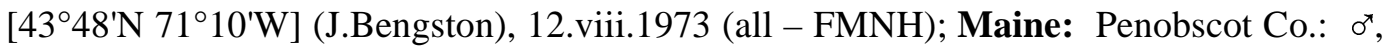

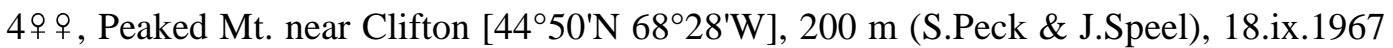

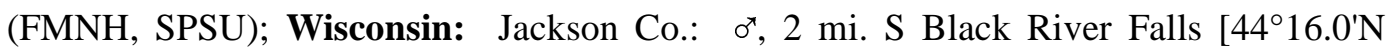
90 50.5'W] (W.Suter), 6.v.1976; CANADA: Québec: 우, Hull Co., Gatineau Park

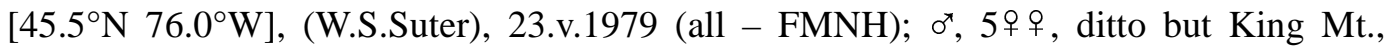
24.v.1979 (FMNH, KSEM, SPSU).
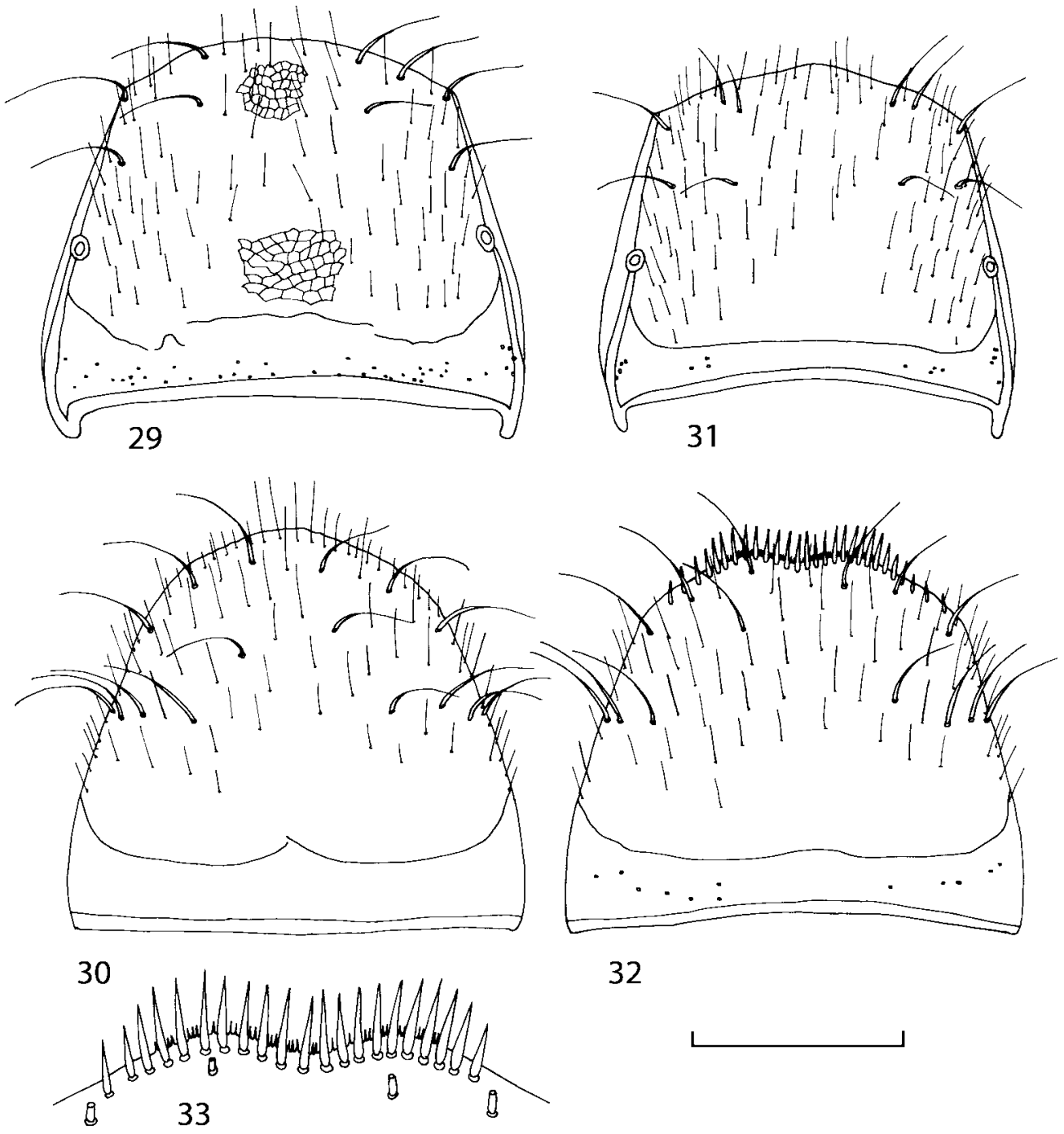

32

FIGURES 29-33. Abdominal segment 8 of Geostiba appalachigena Gusarov, sp. n. (paratypes from Black Mountain, West Virginia). 29 - male tergum $8 ; 30$ - male sternum $8 ; 31$ - female tergum $8 ; 32$ - female sternum 8,33 - apex of female sternum 8 . Scale bar 0.2 mm (29-32), $0.1 \mathrm{~mm}$ (33). 
Diagnosis. Geostiba appalachigena can be distinguished from other Nearctic species of Geostiba by having large eyes (temple length to eye length ratio 2.3-2.7), pronotal pubescence of type V, well developed wings, long elytra (pronotum length to elytron length ratio 0.96), the presence of two short parallel carinae in the middle of male abdominal tergum 7 in front of posterior margin, the shape of the aedeagus (Figs. 34-42, 44-50) and the shape of the spermatheca (Fig. 43).

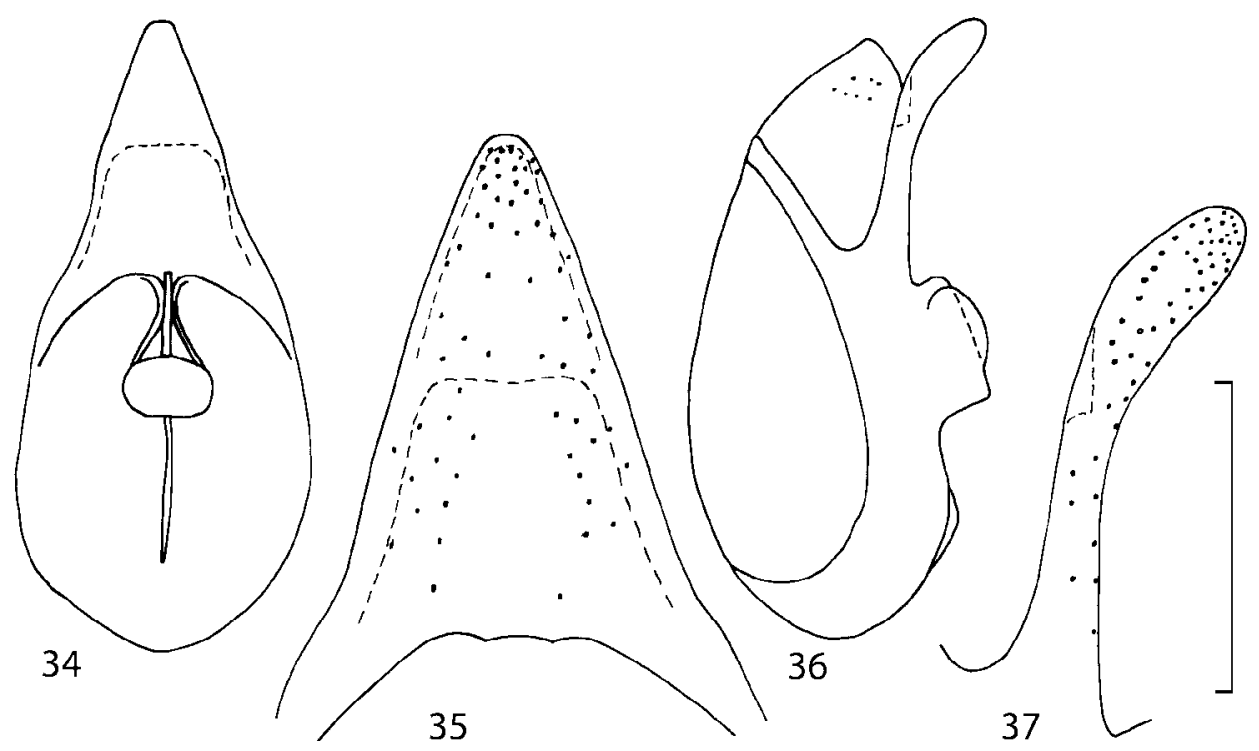

FIGURES 34-37. Aedeagus of Geostiba appalachigena Gusarov, sp. n. (paratype from Black Mountain, West Virginia). 34 - median lobe, ventral view; 35 - apex of median lobe, ventral view; 36 - median lobe, lateral view; 37 - apex of median lobe, lateral view. Scale bar $0.2 \mathrm{~mm}(34,36)$, $0.1 \mathrm{~mm}(35,37)$.

Description. Length 1.9-2.4 mm. Brown or dark brown, elytra and abdominal apex often lighter, antennae brown or yellowish brown, legs and mouthparts brownish yellow. Body parallel-sided.

Head as wide as long, surface on disk with fine isodiametric microsculpture, puncturation very fine, distance between punctures equal to 3-4 times their diameter. Temple length to eye length ratio 2.3-2.7. Antennal article 2 longer than article 3 , article 4 slightly transverse (width to length ratio 1.2), articles 5-10 transverse (ratio 1.5-1.6), last article as long as 9 and 10 combined (Fig. 16); in smaller specimens articles 4-10 more transverse.

Pronotum slightly transverse, width $0.4-0.47 \mathrm{~mm}$, width to length ratio 1.1, wider than head (pronotal width to head width ratio 1.1); microsculpture and puncturation as on head. Pronotal pubescence of type V. Elytra measured from humeral angle longer than pronotum (pronotal length to elytral length ratio 0.96), wider than long (1.2), with fine isodiametric microsculpture and fine, somewhat asperate puncturation, distance between punctures equals 2-3 times their diameter. Elytral suture behind scutellum raised in both sexes. Wings fully developed. 
Abdominal terga with fine microsculpture of transverse meshes, with fine and sparse between punctures equals 3-7 times their diameter. Tergum 7 with white edge.
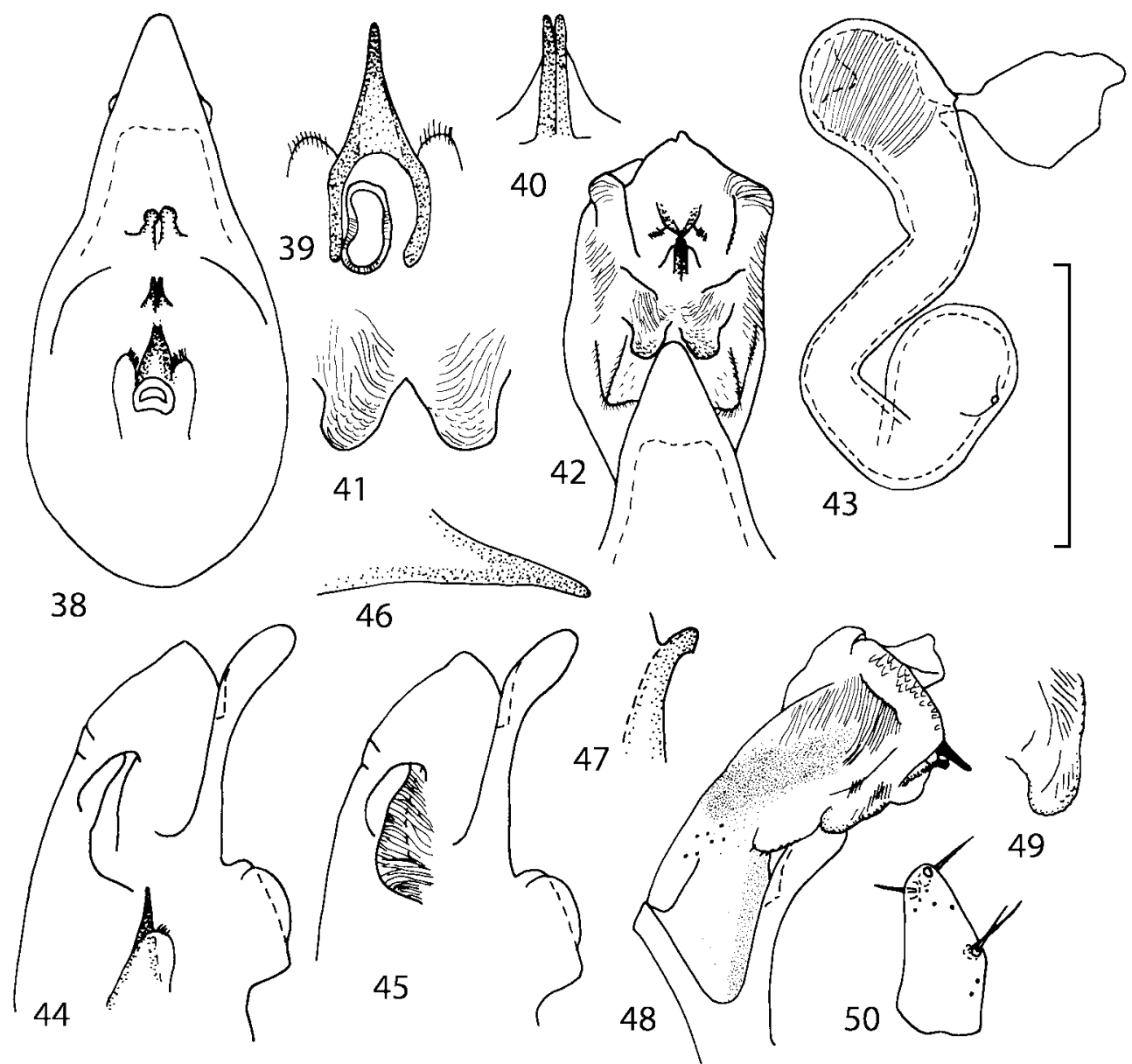

FIGURES 38-50. Genitalia of Geostiba appalachigena Gusarov, sp. n. (paratypes from Black Mountain (38, 40-45, 47-50) and Back Allegheny Mountain $(39,46)$, West Virginia). 38 - details of internal sac retracted into median lobe, ventral view; 39 - copulatory piece of internal sac, dorsal view; 40 - medial lamellae of internal sac, ventral view; 41 distal diverticula of everted internal sac, ventral view; 42 - everted internal sac, ventral view; 43 - spermatheca; 44-45 - details of internal sac retracted into median lobe, lateral view; 46 - copulatory piece of internal sac, lateral view; 47 medial lamella of internal sac, lateral view; 48 - everted internal sac, lateral view; 49 - right distal diverticulum of everted internal sac, lateral view; 50 - apex of left paramere, side facing median lobe. Scale bar $0.2 \mathrm{~mm}(38,42,44-45,48), 0.1 \mathrm{~mm}(39-41,43,46-47,49-50)$.

Male tergum 7 with two medial carinae in front of posterior margin. Male tergum 8 with four small carinae in front of posterior margin, posterior margin slightly convex (Fig. 29), in some specimens with two or four denticles behind the carinae. Male sternum 8 with convex posterior margin (Fig. 30). 
Female tergum 8 with slightly convex posterior margin (Fig. 31), sternum 8 with shallow emargination (Figs. 32-33).

Aedeagus as in Figs. 34-42, 44-50. Apex of median lobe in lateral view bent ventrally and widened apically (Figs. 36-37), distal diverticula of internal sac in ventral view wide (Figs. 41-42).

Spermatheca as in Fig. 43.

Distribution. Widespread in eastern North America (West Virginia, Virginia, Maryland, Pennsylvania, New Jersey, New York, Massachusetts, Rhode Island, New Hampshire, Maine, Wisconsin, Québec). In the southern extreme of its range (Virginia and West Virginia) it occurs only at higher altitudes (mostly above $1200 \mathrm{~m}$ ), in the north it occurs at low altitudes (down to $300 \mathrm{~m}$ in New York and Pennsylvania) (Figs. 336-338).

Natural History. Geostiba appalachigena lives in forest litter and in the southern portion of its range (in Virginia and West Virginia) it occurs almost exclusively in pure conifer or mixed forest with red spruce (Picea rubens) and/or fir (Abies).

Etymology: The specific name is derived from the word Appalachian and the Latin verb gigno (to be born, to arise). It refers to the geographical distribution of this species.

\section{Geostiba (Sibiota) bicarinata Lohse \& Smetana, 1988 (Figs. 51-71)}

Geostiba bicarinata Lohse \& Smetana, 1988: 273, ex parte. Geostiba bicarinata: Pace, 1997: 104.

Type material. Holotype, ơ , UNITED STATES: North Carolina: Haywood Co.: Richland Balsam Mt. [35²2'01"N 8259'26"W], 1860-1950 m (A.Smetana), 27.v.1986 (CNCI); allotype, 우, ditto; paratypes: $50^{\star} 0^{x}, 3$ 우우, ditto; $40^{\pi} 0^{\star}$, 우, ditto but 1850-1950 m, 25.v.1986 (all - CNCI).

Some paratypes of $G$. bicarinata belong to other species: Geostiba pluvigena Gusarov, sp. n.: $\sigma^{\star}$, North Carolina: Haywood Co., Blue Ridge Parkway, Browning Knob Mt., 1830-1890 m (A.Smetana), 28.v.1986 (examined) (CNCI). Two other paratypes were not found in CNCI, but their locality data are listed by Lohse and Smetana (1988: 275). My collecting efforts demonstrated that these paratypes originate from the mountain massifs were G. bicarinata does not occur. These presumably misidentified paratypes belong to G. alticola (one specimen, Buncombe Co.: base of Mt. Mitchell at Blue Ridge Parkway, about $1650 \mathrm{~m}$ (A.Smetana), 3.vi.1986) and G. nimbicola (one specimen, Great Smoky Mountains National Park, Clingmans Dome, 1950-2020 m, (A.Smetana) 2.vi.1986).

Additional material. UNITED STATES: North Carolina: Haywood Co.: 2우우, Richland Balsam Mt., 1829m (J.F. Cornell), fir duff, 26.iv.1974 (KSEM); Haywood Co. / Jackson Co.: 15 specimens, Richland Balsam Mt., near summit, 14 km S Waynesville, $35^{\circ} 22.50^{\prime} \mathrm{N} 82^{\circ} 59.43^{\prime} \mathrm{W}, 1950 \mathrm{~m}$, in forest litter, Picea rubens, Abies fraseri, Vaccinium (V.I.Gusarov), 3.vi.2001; 12 specimens, ditto but W slope of Richland Balsam Mt., $35^{\circ} 22.28^{\prime} \mathrm{N} 82^{\circ} 59.42^{\prime} \mathrm{W}, 1900 \mathrm{~m}$, Picea rubens, Abies fraseri; 15 specimens, ditto but $\mathrm{S}$ 
slope of Richland Balsam Mt., 35 $21.04^{\prime} \mathrm{N} 82^{\circ} 59.56^{\prime} \mathrm{W}, 1850 \mathrm{~m}$, Picea rubens, Abies

fraseri, Betula, Oxalis; 14 specimens, Blue Ridge Parkway, $11 \mathrm{~km}$ SSW Waynesville, $35^{\circ} 23.3^{\prime} \mathrm{N} 83^{\circ} 02.43^{\prime} \mathrm{W}, 1800 \mathrm{~m}$, in forest litter, Picea rubens, Abies fraseri, Betula, Oxalis (V.I.Gusarov), 2.vi.2001; 10 specimens, ditto but $13 \mathrm{~km} \mathrm{~S}$ Waynesville, $35^{\circ} 22.12^{\prime} \mathrm{N}$ $82^{\circ} 59.65^{\prime} \mathrm{W}, 1800 \mathrm{~m}$, in forest litter, Picea rubens, Abies fraseri, Oxalis (V.I.Gusarov), 3.vi.2001 (all - KSEM and SPSU); 우, Blue Ridge Parkway, Grassy Ridge Mine Overlook, $8 \mathrm{~km}$ SSW Waynesville, $35^{\circ} 24.94^{\prime} \mathrm{N} 83^{\circ} 02.80^{\prime} \mathrm{W}, 1650 \mathrm{~m}$, in forest litter, Tsuga, Quercus, Betula (V.I.Gusarov), 2.vi.2001; Haywood Co. / Buncombe Co.: $0^{x}$, Little Pisgah Mt., near summit, $35^{\circ} 25.48^{\prime} \mathrm{N} 82^{\circ} 45.51^{\prime} \mathrm{W}, 1730-1760 \mathrm{~m}$, in forest litter, Fagus, Quercus, Rhododendron (V.I.Gusarov), 20.ix.2001 (all - SPSU).
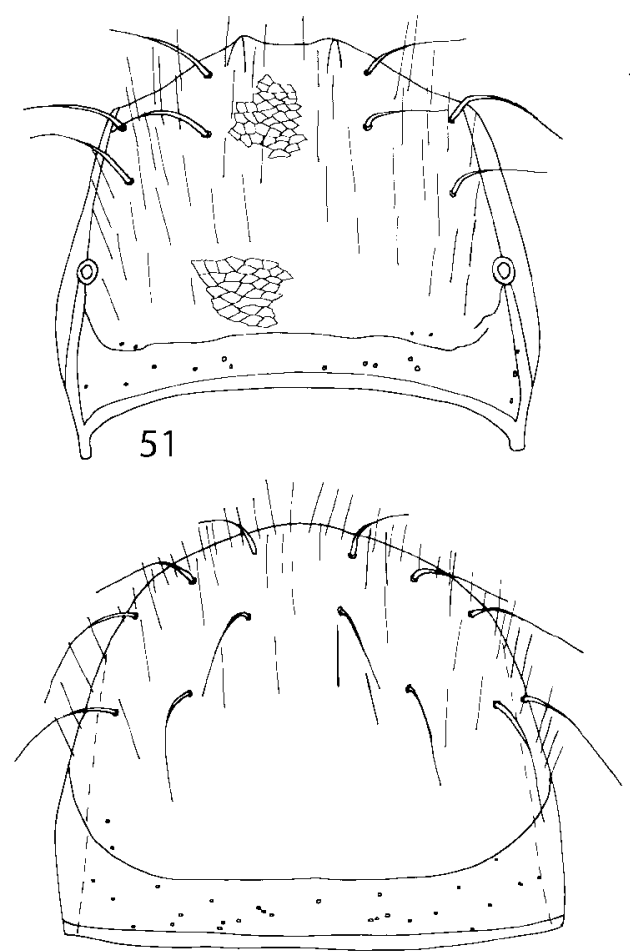

52

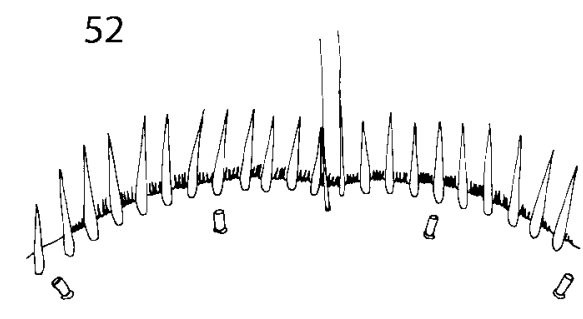

55
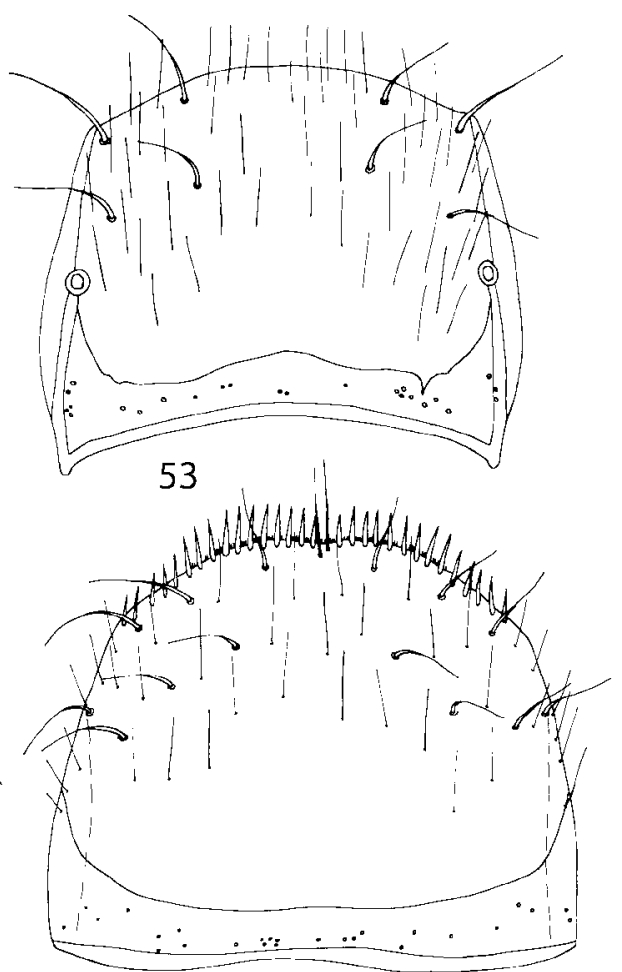

54

FIGURES 51-56. Abdominal segments 7-8 of Geostiba bicarinata Lohse \& Smetana (Richland Balsam Mountain, North Carolina). 51 - male tergum 8; 52 - male sternum 8; 53 - female tergum 8 ; 54 - female sternum 8,55 - apex of female sternum $8 ; 56$ - medial portion of male tergum 7 , posterior down. Scale bar $0.2 \mathrm{~mm}(51-54,56), 0.1 \mathrm{~mm}(55)$. 
Diagnosis. Geostiba bicarinata can be distinguished from other Nearctic species of Geostiba by having small eyes (temple length to eye length ratio 3.8-5.0), pronotal pubescence of type $\mathrm{V}$, reduced wings, short elytra (pronotum length to elytron length ratio 1.3), the presence of two short parallel carinae in the middle of male abdominal tergum 7 in front of posterior margin, the shape of the aedeagus (Figs. 57-64, 66-71) and the shape of the spermatheca (Fig. 65).

Geostiba bicarinata is closely related to G. graveyardensis but differs in the following: the apex of median lobe in lateral view not bent ventrally (Figs. 59-60, 79-80), in ventral view without apical process (Figs. 57-58, 77-78).

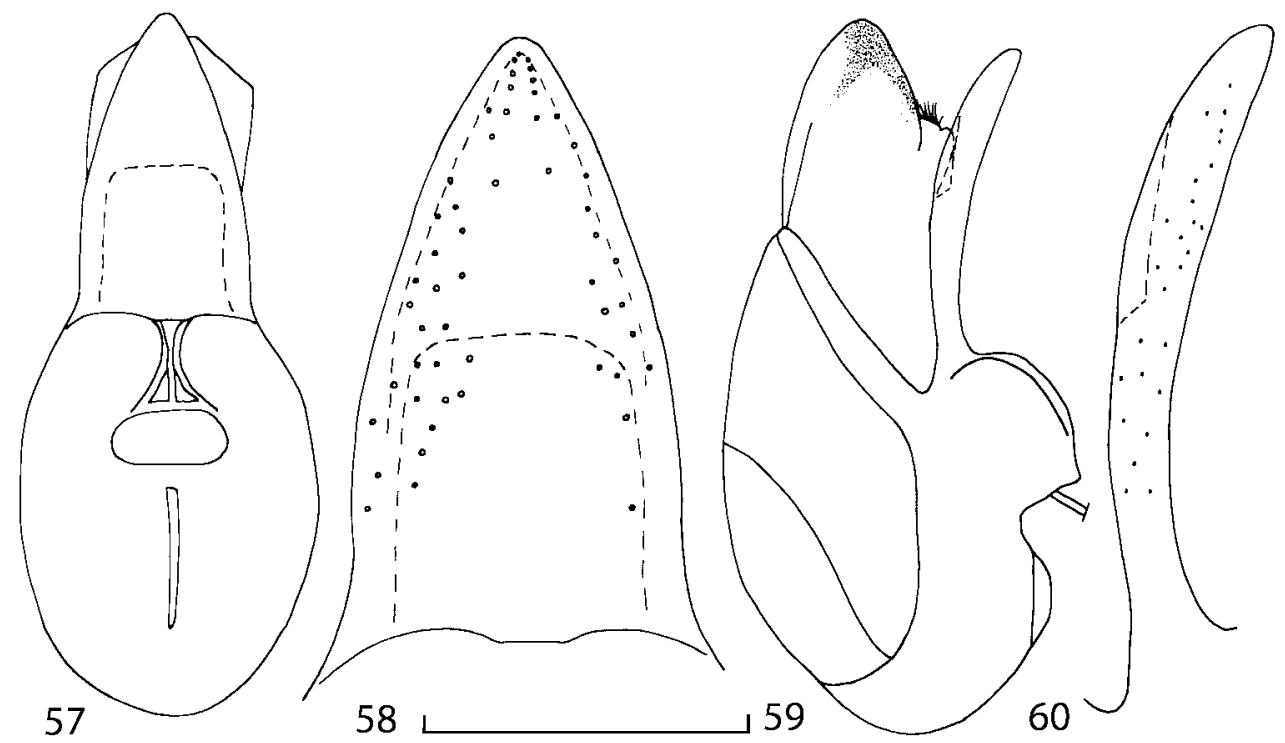

FIGURES 57-60. Aedeagus of Geostiba bicarinata Lohse \& Smetana (Richland Balsam Mountain, North Carolina). 57 - median lobe, ventral view; 58 - apex of median lobe, ventral view; 59 median lobe, lateral view; 60 - apex of median lobe, lateral view. Scale bar $0.2 \mathrm{~mm}(57,59), 0.1$ $\mathrm{mm}(58,60)$.

Description. Length 2.0-2.3 mm. Dark brown, elytra often lighter, antennae brown, legs and mouthparts yellowish brown. Body parallel-sided.

Head as wide as long, surface on disk with fine isodiametric microsculpture, puncturation very fine, distance between punctures equal to 3-4 times their diameter. Temple length to eye length ratio 3.8-5.0. Antennal article 2 longer than article 3, article 4 slightly transverse, 5-10 transverse, last article as long as 9 and 10 combined (as in Fig. 16).

Pronotum slightly transverse, width $0.4-0.46 \mathrm{~mm}$, width to length ratio 1.1 , wider than head (pronotal width to head width ratio 1.2); microsculpture and puncturation as on head. Pronotal pubescence of type V. Elytra measured from humeral angle shorter than pronotum (pronotal length to elytral length ratio 1.3), wider than long (1.5), with fine isodiamet- 
ric microsculpture and fine, asperate puncturation, distance between punctures equals 2-3 times their diameter. Elytral suture behind scutellum slightly raised in both sexes. Wings reduced to short vestiges, shorter than elytra.

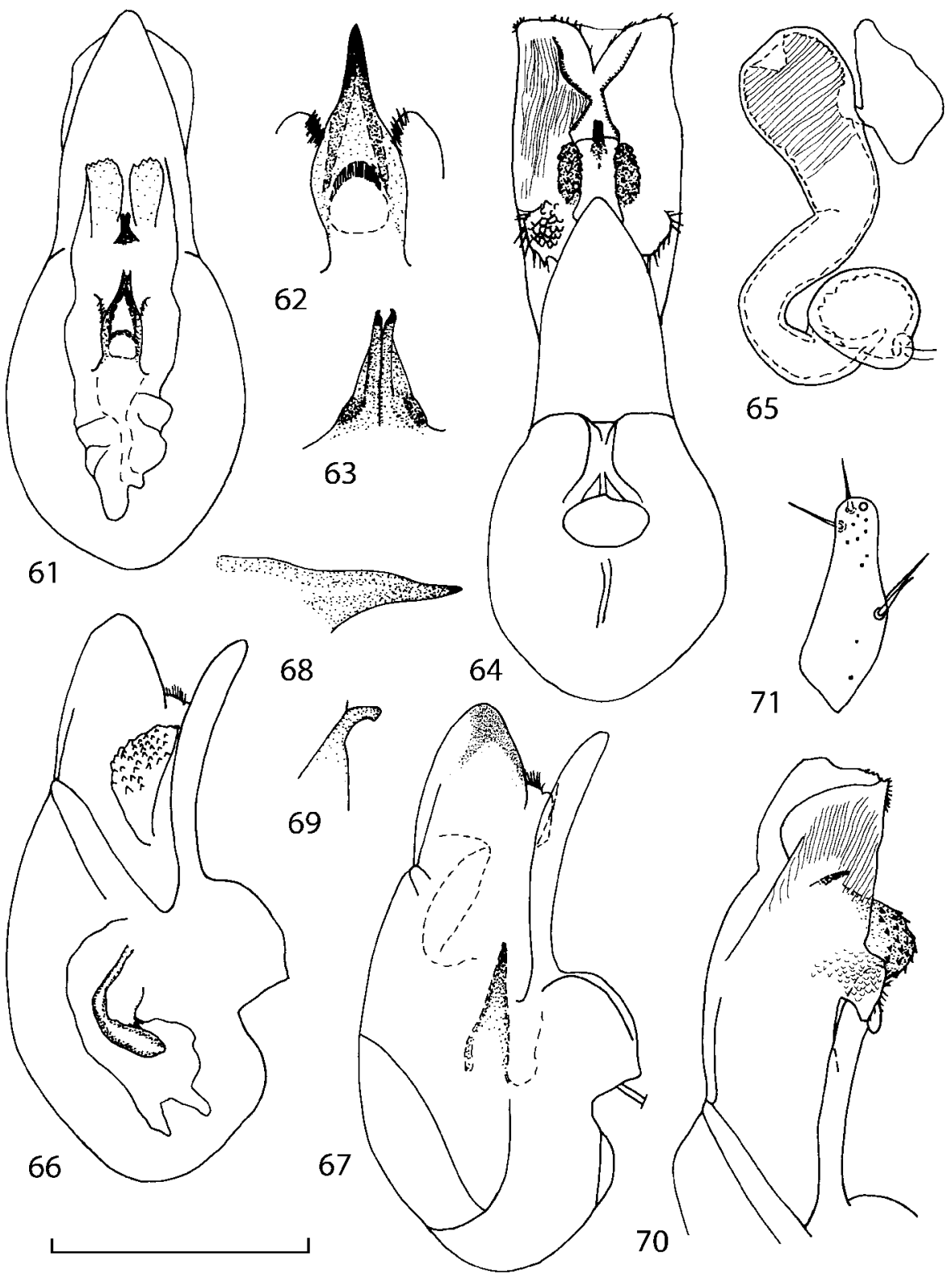

FIGURES 61-71. Genitalia of Geostiba bicarinata Lohse \& Smetana (Richland Balsam Mountain, North Carolina). 61 - details of internal sac retracted into median lobe, ventral view; 62 - copulatory piece of internal sac, dorsal view; 63 - medial lamellae of internal sac, ventral view; 64 everted internal sac, ventral view; 65 - spermatheca; 66-67 - details of internal sac retracted into median lobe, lateral view; 68 - copulatory piece of internal sac, lateral view; 69 - medial lamella of internal sac, lateral view; 70 - everted internal sac, lateral view; 71 - apex of left paramere, side facing median lobe. Scale bar $0.2 \mathrm{~mm}(61,64,66-67,70), 0.1 \mathrm{~mm}(62-63,65,68-69,71)$. 
Abdominal terga with fine microsculpture of transverse meshes, with fine and sparse puncturation, puncturation becoming finer towards abdomen apex, on terga 3-5 distance between punctures equals 3-7 times their diameter. Tergum 7 without white edge.

In males pronotum slightly flattened on disc. Male tergum 7 with two medial carinae in front of posterior margin. Male tergum 8 with two or four weak and short carinae in front of posterior margin, and two weak projections at posterior margin (Fig. 51). Male sternum 8 with convex posterior margin (Fig. 52).

Female tergum 8 with slightly convex posterior margin (Fig. 53), posterior margin of sternum 8 slightly concave medially (Figs. 54-55).

Aedeagus as in Figs. 57-64, 66-71. Apex of median lobe in ventral view broad, with convex outline, without apical process (Figs. 57-58), in lateral view not bent ventrally (Figs. 59-60), distal diverticula of internal sac with numerous denticles (Figs. 61, 64, 70), in ventral view narrow (Fig. 64), in lateral view broad (Fig. 70).

Spermatheca as in Fig. 65.

Distribution. Known from the Great Balsam Mountains and Little Pisgah Mountain (North Carolina) (Figs. 338, 340).

Natural History. Geostiba bicarinata was collected by sifting forest litter at altitudes above $1600 \mathrm{~m}$ mostly in pure conifer or mixed forest with red spruce (Picea rubens) and Fraser's fir (Abies fraseri).

\section{Geostiba (Sibiota) graveyardensis Pace, 1997 (Figs. 72-93)}

Geostiba (Ditroposipalia) graveyardensis Pace, 1997: 102.

Material. UNITED STATES: North Carolina: Haywood Co.: 2 specimens, Graveyard Fields at Blue Ridge Parkway, $22 \mathrm{~km} \mathrm{SE}$ Waynesville, right bank of the river, $35^{\circ} 19.2^{\prime} \mathrm{N} 82^{\circ} 50.7^{\prime} \mathrm{W}, 1550 \mathrm{~m}$, in forest litter by the river, Picea, Betula, Rhododendron (V.I.Gusarov), 20.ix.2001; 48 specimens, Black Balsam Knob Road N of Blue Ridge Parkway, $21 \mathrm{~km}$ SSE Waynesville, $35^{\circ} 19.1^{\prime} \mathrm{N} 82^{\circ} 52.6^{\prime} \mathrm{W}, 1800 \mathrm{~m}$, in forest litter, Picea (V.I.Gusarov), 20.ix.2001 (all KSEM and SPSU).

Type locality. UNITED STATES: North Carolina: Haywood Co.: Graveyard Fields at Blue Ridge Parkway (Pace 1997).

Diagnosis. Geostiba graveyardensis can be distinguished from other Nearctic species of Geostiba by having small eyes (temple length to eye length ratio 2.8-3.8), pronotal pubescence of type $\mathrm{V}$, reduced wings, short elytra (pronotum length to elytron length ratio 1.3), the presence of two short parallel carinae in the middle of abdominal tergum 7 in front of posterior margin, the shape of the aedeagus (Figs. 77-85, 87-93) and the shape of the spermatheca (Fig. 86).

Geostiba graveyardensis is closely related to G. bicarinata but differs in the following: the apex of median lobe in lateral view bent ventrally (Figs. 79-80, 59-60), in ventral view with apical process (Figs. 77-78, 57-58). 
Description. Length 1.9-2.3 mm. Brown or dark brown, elytra and apex of abdomen

often lighter, antennae light brown, legs and mouthparts brownish yellow. Body parallelsided.

Head as wide as long, surface on disk with fine isodiametric microsculpture, puncturation very fine, distance between punctures equal to 3-4 times their diameter. Temple length to eye length ratio 2.8-3.8. Antennal article 2 longer than article 3 , article 4 slightly transverse, 5-10 transverse, last article longer than 9 and 10 combined (as in Fig. 16).

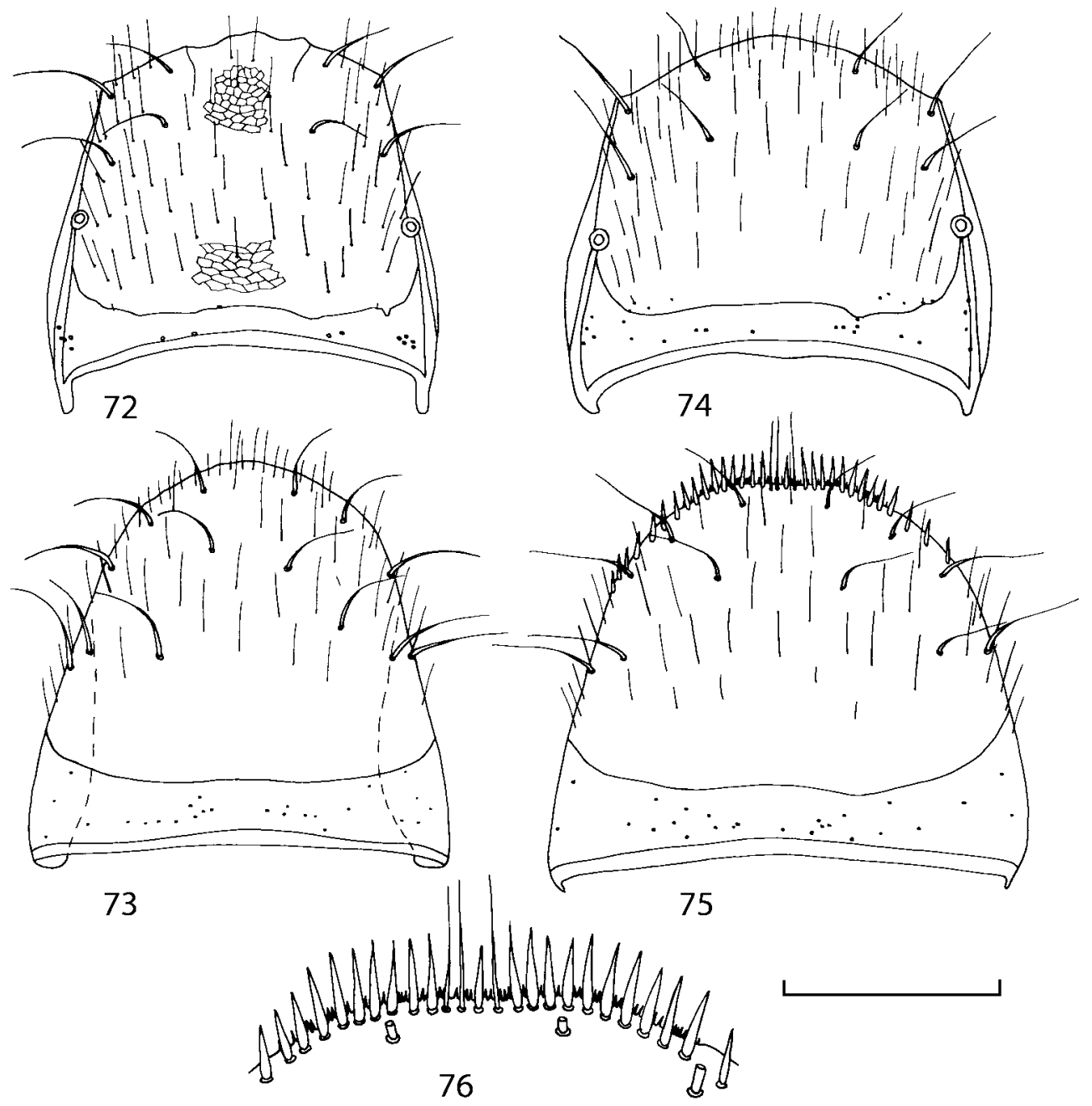

FIGURES 72-76. Abdominal segment 8 of Geostiba graveyardensis Pace (Graveyard Fields, North Carolina). 72 - male tergum $8 ; 73$ - male sternum $8 ; 74$ - female tergum $8 ; 75$ - female sternum 8,76 - apex of female sternum 8 . Scale bar $0.2 \mathrm{~mm}$ (72-75), $0.1 \mathrm{~mm}$ (76).

Pronotum slightly transverse, width $0.41-0.44 \mathrm{~mm}$, width to length ratio 1.1 , wider than head (pronotal width to head width ratio 1.2); microsculpture and puncturation as on 
head. Pronotal pubescence of type V. Elytra measured from humeral angle shorter than pronotum (pronotal length to elytral length ratio 1.3), wider than long (1.5), with fine isodiametric microsculpture and fine asperate puncturation, distance between punctures equals 2-3 times their diameter. Elytral suture behind scutellum slightly raised in both sexes. Wings reduced to short vestiges, shorter than elytra.

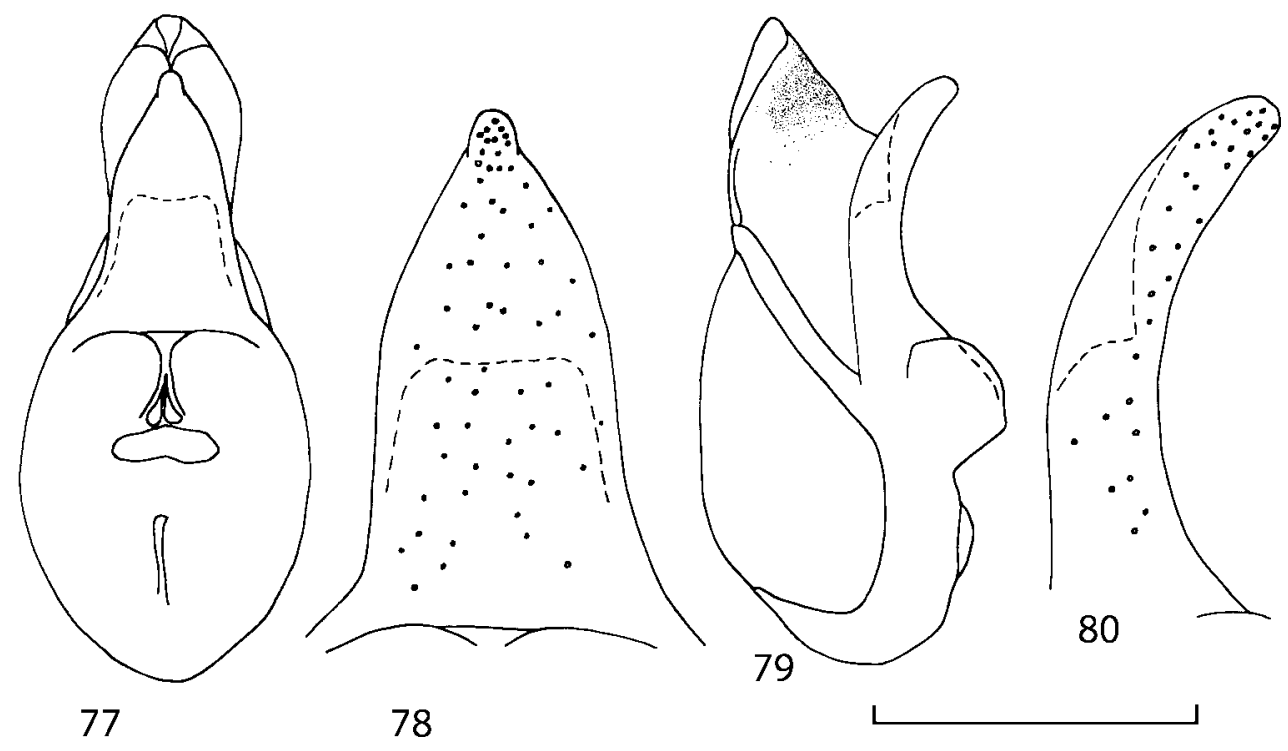

FIGURES 77-80. Aedeagus of Geostiba graveyardensis Pace (Graveyard Fields, North Carolina). 77 - median lobe, ventral view; 78 - apex of median lobe, ventral view; 79 - median lobe, lateral view; 80 - apex of median lobe, lateral view. Scale bar $0.2 \mathrm{~mm}(77,79), 0.1 \mathrm{~mm}(78,80)$.

Abdominal terga with fine microsculpture of transverse meshes, with fine and sparse puncturation, puncturation becoming finer towards abdomen apex, on terga 3-5 distance between punctures equals 3-7 times their diameter. Tergum 7 without white edge.

Male tergum 7 with two medial carinae in front of posterior margin. Male tergum 8 with two or four weak and short carinae in front of posterior margin, posterior margin convex (Fig. 72). Male sternum 8 with convex posterior margin (Fig. 73).

Female tergum 8 with convex posterior margin (Fig. 74), posterior margin of sternum 8 concave medially (Figs. 75-76).

Aedeagus as in Figs. 77-85, 87-93. Apex of median lobe in ventral view with apical process (Figs. 77-78), in lateral view bent ventrally (Figs. 79-80), distal diverticula of internal sac with numerous denticles (Figs. 81, 84, 91-92), in ventral view narrow (Figs. 84-85), in lateral view broad (Figs. 91-92).

Spermatheca as in Fig. 86.

Distribution. Known from the Graveyard Ridge and Black Balsam Knob in the Great Balsam Mountains - Pisgah Ridge massif (North Carolina) (Figs. 338, 340). 
Natural History. Geostiba graveyardensis was collected by sifting forest litter at altirubens).

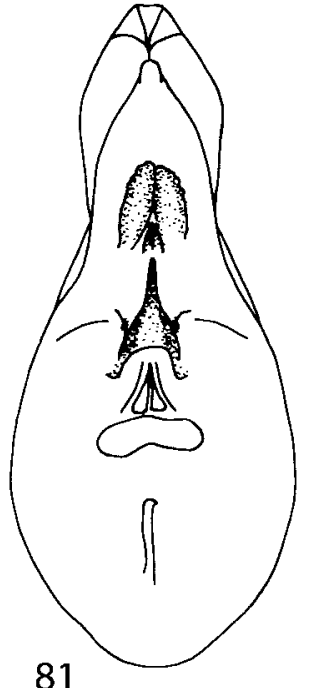

81

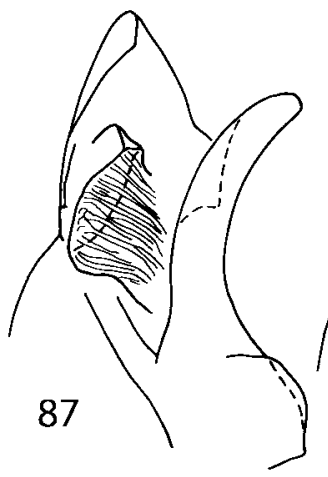

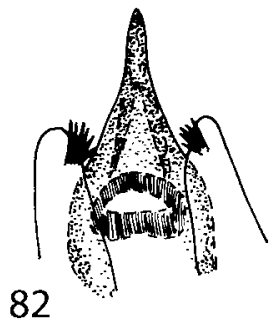

82

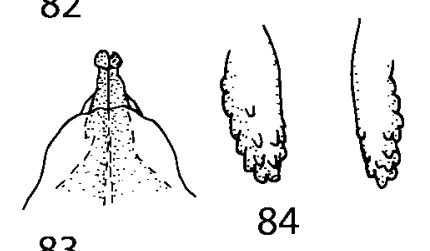

83

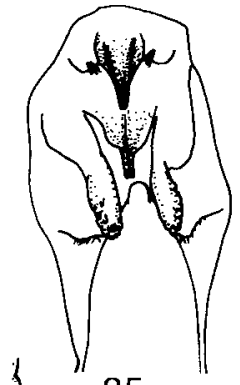

85

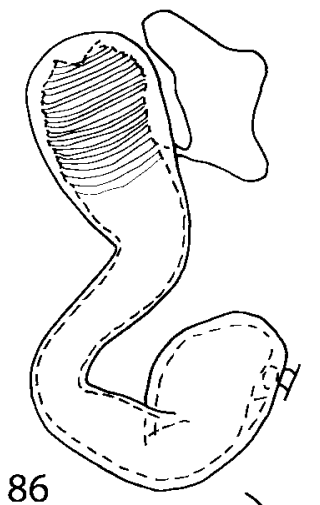

86

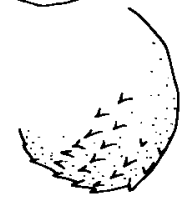

89
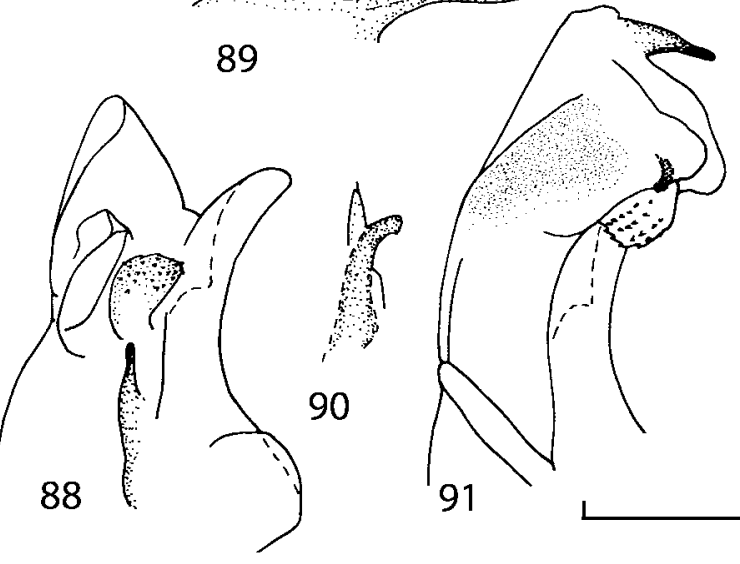

92

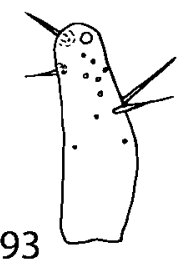

FIGURES 81-93. Genitalia of Geostiba graveyardensis Pace (Graveyard Fields (81, 84-88, 91-93) and Black Balsam Knob Road (82-83, 89-90), North Carolina). 81 - details of internal sac retracted into median lobe, ventral view; 82 - copulatory piece of internal sac, dorsal view; 83 - medial lamellae of internal sac, ventral view; 84 - distal diverticula of everted internal sac, ventral view; 85 - everted internal sac, ventral view; 86 - spermatheca; 87-88 - details of internal sac retracted into median lobe, lateral view; 89 - copulatory piece of internal sac, lateral view; 90 - medial lamella of internal sac, lateral view; 91 - everted internal sac, lateral view; 92 - right distal diverticulum of everted internal sac, lateral view; 93 - apex of left paramere, side facing median lobe. Scale bar 0.2 $\mathrm{mm}(81,85,87-88,91), 0.1 \mathrm{~mm}(82-84,86,89-90,92-93)$.

\section{Geostiba (Sibiota) nimbicola Lohse \& Smetana, 1988 (Figs. 94-119)}

Geostiba nimbicola Lohse \& Smetana, 1988: 275.

Geostiba bicarinata: Lohse \& Smetana, 1988: 273, ex parte (misidentification). Geostiba nimbicola: Pace, 1997: 106. 

83⒉'55"W], 1950-2020 m, (A.Smetana) 2.vi.1986 (CNCI); allotype, 우, same data as the holotype; paratypes: $30^{x} 0^{x}$, 9 , ditto (all-CNCI).

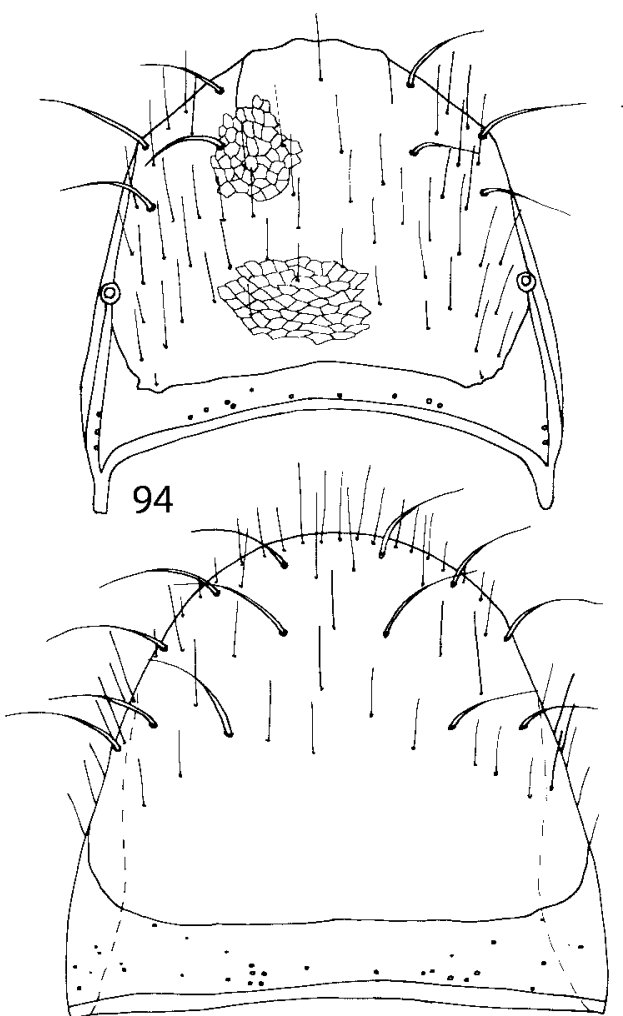

95

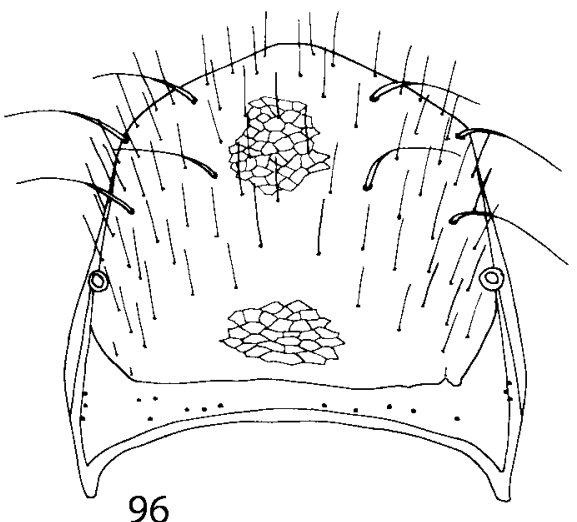

96

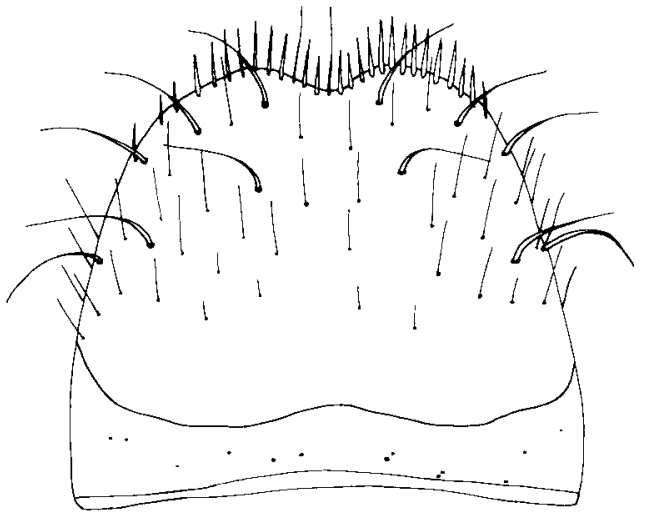

97

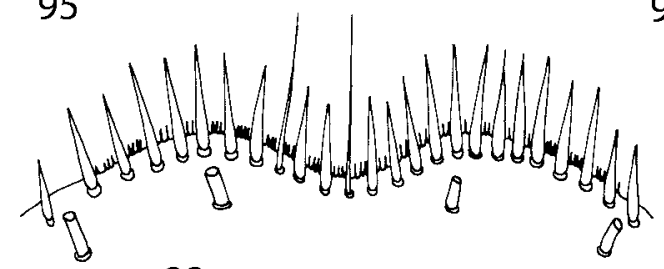

98

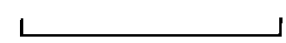

99

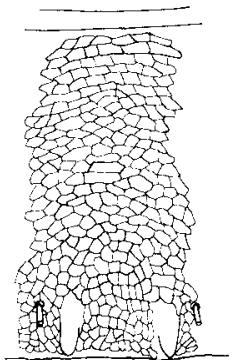

FIGURES 94-99. Abdominal segments 7-8 of Geostiba nimbicola Lohse \& Smetana (Mount Sterling Ridge Trail, Tennessee). 94 - male tergum 8; 95 - male sternum 8; 96 - female tergum 8; 97 female sternum 8,98 - apex of female sternum $8 ; 99$ - medial portion of male tergum 7 , posterior down. Scale bar $0.2 \mathrm{~mm}(94-97,99), 0.1 \mathrm{~mm}(98)$.

Additional material. UNITED STATES: Tennessee / North Carolina: Sevier Co. / Swain Co.: $0^{x}$ (with missing abdomen), same data as the holotype (CNCI); $20^{x} 0^{x}, 3$ 우 우, 
ditto but (W.S.Suter) 29.v.1982 (KSEM); Tennessee: Sevier Co.: $0^{\star}, 4$ 우우, Great Smoky Mts. National Park, Ramsey Cascade, [35 $42^{\prime} 30^{\prime \prime N} 83^{\circ} 18^{\prime} 02^{\prime \prime W}$, moss on rock (Lackey), 21.vii.1956 (FMNH, SPSU); North Carolina: Haywood Co.: 15 specimens, Mount Sterling Ridge, $26 \mathrm{~km}$ NNW Waynesville, $35^{\circ} 41.9^{\prime} \mathrm{N} 83^{\circ} 07.5^{\prime} \mathrm{W}, 1700 \mathrm{~m}$, in forest litter, Picea, Abies, Quercus, Betula (V.I.Gusarov), 22.ix.2001; 14 specimens, ditto but, $35^{\circ} 42.1^{\prime} \mathrm{N} 83^{\circ} 06.8^{\prime} \mathrm{W}, 1550 \mathrm{~m}$, Picea, Rhododendron, Betula (all - KSEM and SPSU)

One of the paratypes of G. bicarinata listed by Lohse \& Smetana (1988: 275) (not found in CNCI) must also belong to G. nimbicola (1 specimen, Great Smoky Mountains National Park, Clingmans Dome, 1950-2020 m, (A.Smetana) 2.vi.1986). This assertion is based on the results of my extensive collecting efforts which demonstrated that $G$. bicarinata is restricted to the Great Balsam Mountains - Pisgah Ridge massif.

Diagnosis. Geostiba nimbicola can be distinguished from other Nearctic species of Geostiba by having small eyes (temple length to eye length ratio 3.0-4.0), pronotal pubescence of type $\mathrm{V}$, reduced wings, short elytra (pronotum length to elytron length ratio 1.3), the presence of two short parallel carinae in the middle of abdominal tergum 7 in front of posterior margin, the shape of the aedeagus (Figs. 100-112, 114-119) and the shape of the spermatheca (Fig. 113).

Geostiba nimbicola is closely related to G. pluvigena, G. nebuligena, and G. crepusculigena. Geostiba nimbicola differs from G. pluvigena in having longer and more narrow apex of median lobe without apical denticle (in lateral view) (Figs. 100-107, 126-133); from G. nebuligena in having deeper apical emargination in female sternum 8 (Figs. 9798, 149-150), longer and more narrow apex of median lobe without apical denticle (in lateral view) (Figs. 100-107, 152-156); from G. crepusculigena in lacking obtuse projection on the ventral side of the apex of median lobe (Figs. 102-103, 176-177).

Description. Length 1.6-2.0 mm. Light brown or brown, apex of abdomen often lighter, antennae brownish yellow or light brown, legs and mouthparts brownish yellow. Body parallel-sided.

Head as wide as long, surface on disk with fine isodiametric microsculpture, puncturation very fine, distance between punctures equal to 3-4 times their diameter. Temple length to eye length ratio 3.0-4.0. Antennal article 2 longer than article 3, article 4 transverse (width to length ratio 1.6), articles 5-10 strongly transverse, last article as long as 9 and 10 combined (as in Fig. 17).

Pronotum as wide as long, width $0.37-0.40 \mathrm{~mm}$, wider than head (pronotal width to head width ratio 1.1); microsculpture and puncturation as on head. Pronotal pubescence of type V. Elytra measured from humeral angle shorter than pronotum (pronotal length to elytral length ratio 1.3), wider than long (1.5), with fine isodiametric microsculpture and fine asperate puncturation, distance between punctures equals 2-3 times their diameter. Elytral suture behind scutellum slightly raised in both sexes. Wings reduced to short vestiges, shorter than elytra. 
Abdominal terga with fine microsculpture of transverse meshes, with fine and sparse puncturation, puncturation becoming finer towards abdomen apex, on terga 3-5 distance between punctures equals 3-7 times their diameter. Tergum 7 without white edge.

Male tergum 7 with two medial carinae in front of posterior margin. Male tergum 8 with two weak and short carinae in front of posterior margin, posterior margin convex (Fig. 94). Male sternum 8 with convex posterior margin (Fig. 95).

Female tergum 8 with convex posterior margin (Fig. 96), sternum 8 with emarginate posterior margin (Figs. 97-98).

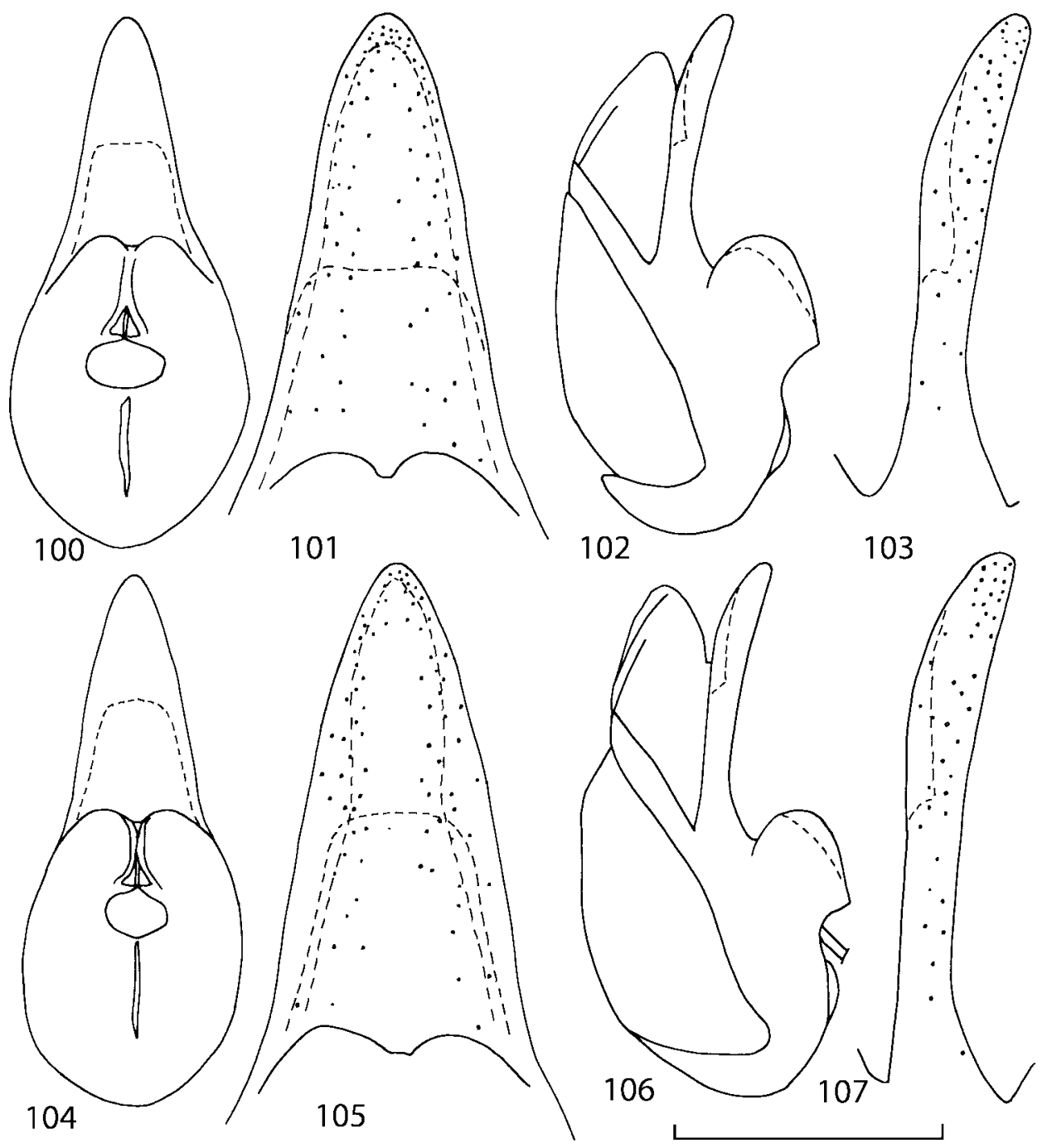

FIGURES 100-107. Aedeagus of Geostiba nimbicola Lohse \& Smetana (100-103 - holotype; 104-107 - Mount Sterling Ridge Trail, Tennessee). 100, 104 - median lobe, ventral view; 101, 105 - apex of median lobe, ventral view; 102, 106 - median lobe, lateral view; 103, 107 - apex of median lobe, lateral view. Scale bar $0.2 \mathrm{~mm}(100,102,104,106), 0.1 \mathrm{~mm}(101,103,105,107)$. 
Aedeagus as in Figs. 100-112, 114-119. Apex of median lobe in ventral view narrow, its outline convex apically (Figs. 100-101, 104-105), in lateral view strait, without apical denticle or obtuse projection ventrally (Figs. 102-103, 106-107), distal diverticula of internal sac in ventral view broad (Figs. 111-112).

Spermatheca as in Fig. 113.

Distribution. Known from the Great Smoky Mountains massif (Tennessee and North Carolina) (Figs. 338, 340).

Natural History. Geostiba nimbicola was collected at altitudes above $1500 \mathrm{~m}$ in moss or in leaf litter in mixed forest with red spruce (Picea rubens), Fraser's fir (Abies fraseri), birch and oak.
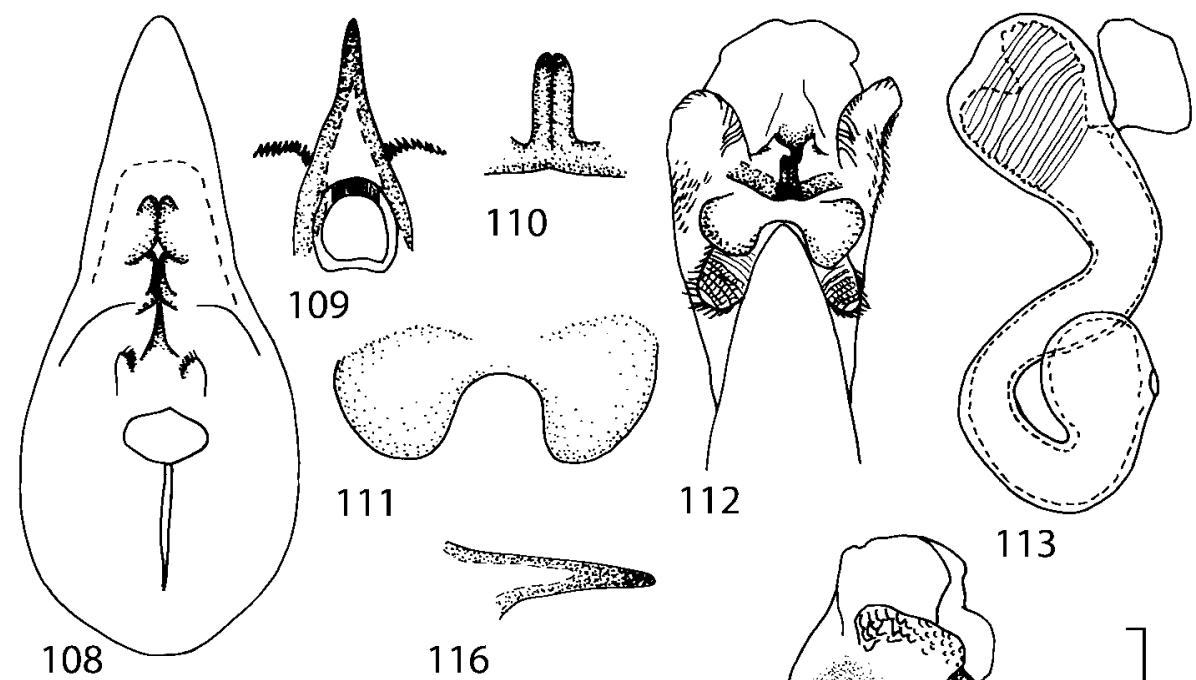

111

112

113
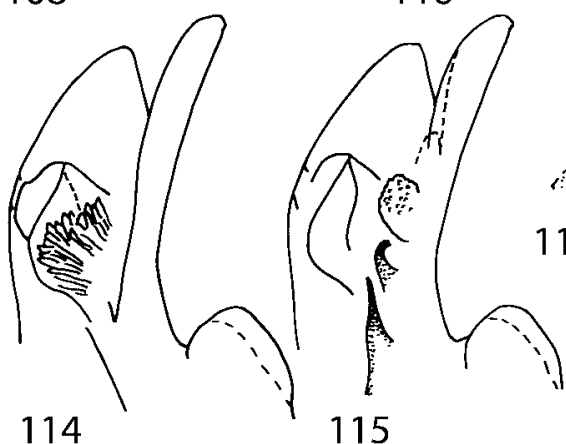

115
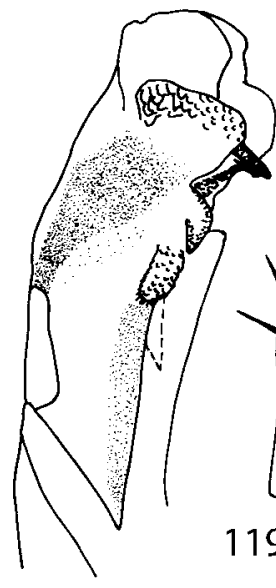

118

FIGURES 108-119. Genitalia of Geostiba nimbicola Lohse \& Smetana (Mount Sterling Ridge Trail, Tennessee). 108 - details of internal sac retracted into median lobe, ventral view; 109 - copulatory piece of internal sac, dorsal view; 110 - medial lamellae of internal sac, ventral view; 111 - distal diverticula of everted internal sac, ventral view; 112 - everted internal sac, ventral view; 113 - spermatheca; 114-115 - details of internal sac retracted into median lobe, lateral view; 116 copulatory piece of internal sac, lateral view; 117 - medial lamella of internal sac, lateral view; 118 - everted internal sac, lateral view; 119 - apex of left paramere, side facing median lobe. Scale bar $0.2 \mathrm{~mm}(108,112,114-115,118), 0.1 \mathrm{~mm}(109-111,113,116-117,119)$. 
Geostiba bicarinata: Lohse \& Smetana, 1988: 273, ex parte (misidentification).

Type material. Holotype, ơ, UNITED STATES: North Carolina: Haywood Co. / Jackson Co.: junction of Blue Ridge Parkway and Balsam Mountain Road, 17 km W Waynesville, $35^{\circ} 29.72^{\prime} \mathrm{N} 83^{\circ} 10.43^{\prime} \mathrm{W}, 1600 \mathrm{~m}$, in forest litter, Picea rubens, Fagus grandifolia, Betula, Rhododendron, Maianthemum canadense, Oxalis (V.I.Gusarov), 2.vi.2001 (KSEM).
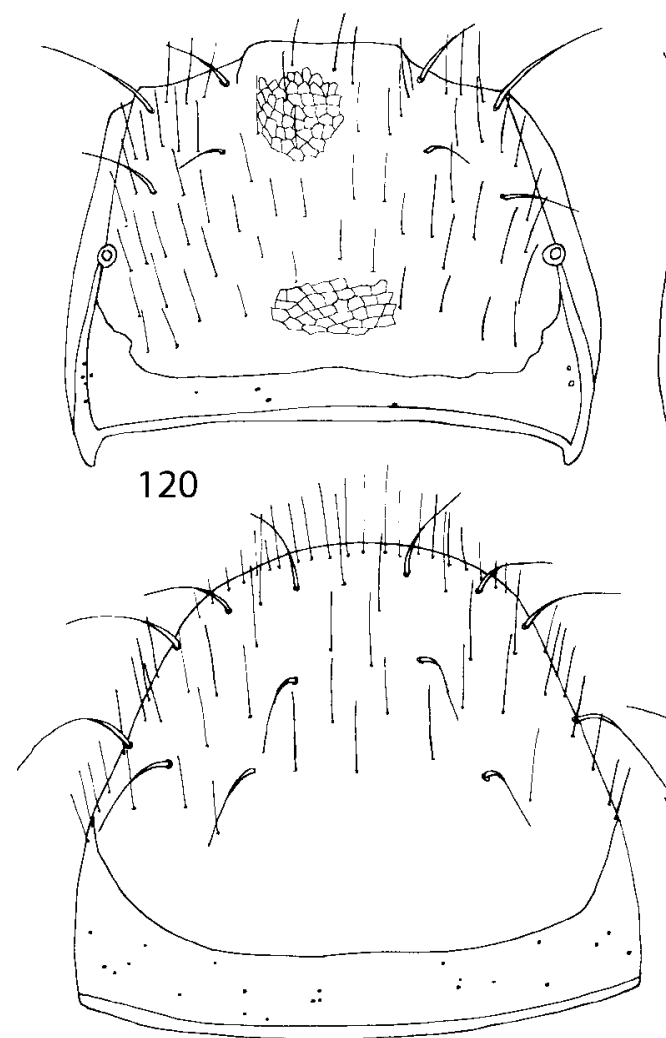

121

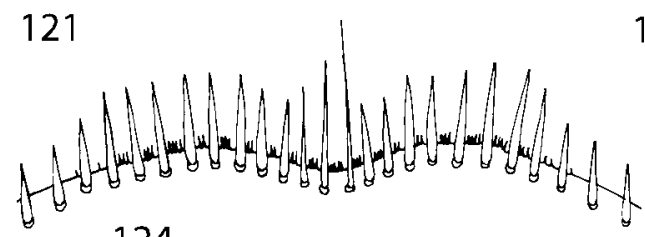

124

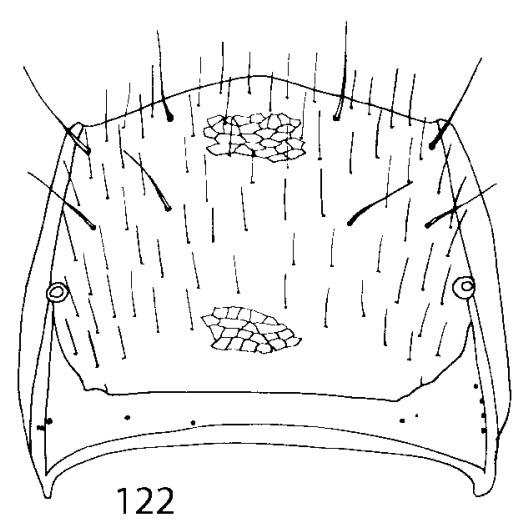

122

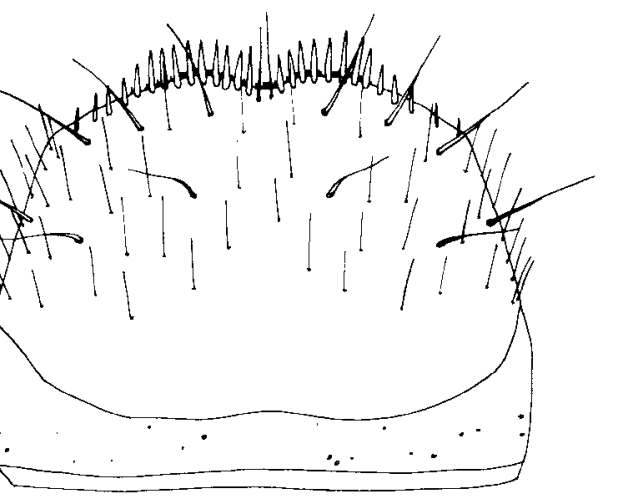

123

FIGURES 120-125. Abdominal segments 7-8 of Geostiba pluvigena Gusarov, sp. n. (paratypes from Waterrock Knob $(120-121,125)$ and junction of Blue Ridge Parkway and Balsam Mountain Road (122-124), North Carolina). 120 - male tergum 8; 121 - male sternum 8; 122 - female tergum $8 ; 123$ - female sternum 8,124 - apex of female sternum $8 ; 125$ - medial portion of male tergum 7, posterior down. Scale bar $0.2 \mathrm{~mm}(120-123,125), 0.1 \mathrm{~mm}(124)$. 
Paratypes: UNITED STATES: North Carolina: Haywood Co. / Jackson Co.: 99

specimens, same data as the holotype (KSEM, AMNH, CNCI, SPSU, FMNH); 43 specimens, Waterrock Knob, N slope, 13 km W Waynesville, 35²8.0' $83^{\circ} 08.2^{\prime} \mathrm{W}, 1900 \mathrm{~m}$, in forest litter, Picea rubens, Abies fraseri, Rubus, Oxalis (V.I.Gusarov), 2.vi.2001 (KSEM, SPSU); Haywood Co.: $o^{x}$, Blue Ridge Parkway, Browning Knob Mt. [35²7'47"N $83^{\circ} 07^{\prime} 55^{\prime \prime W}$ ], 1830-1890 m (A.Smetana), 28.v.1986 (Lohse and Smetana (1988) listed this specimen as a paratype in the type series of G. bicarinata)(CNCI).
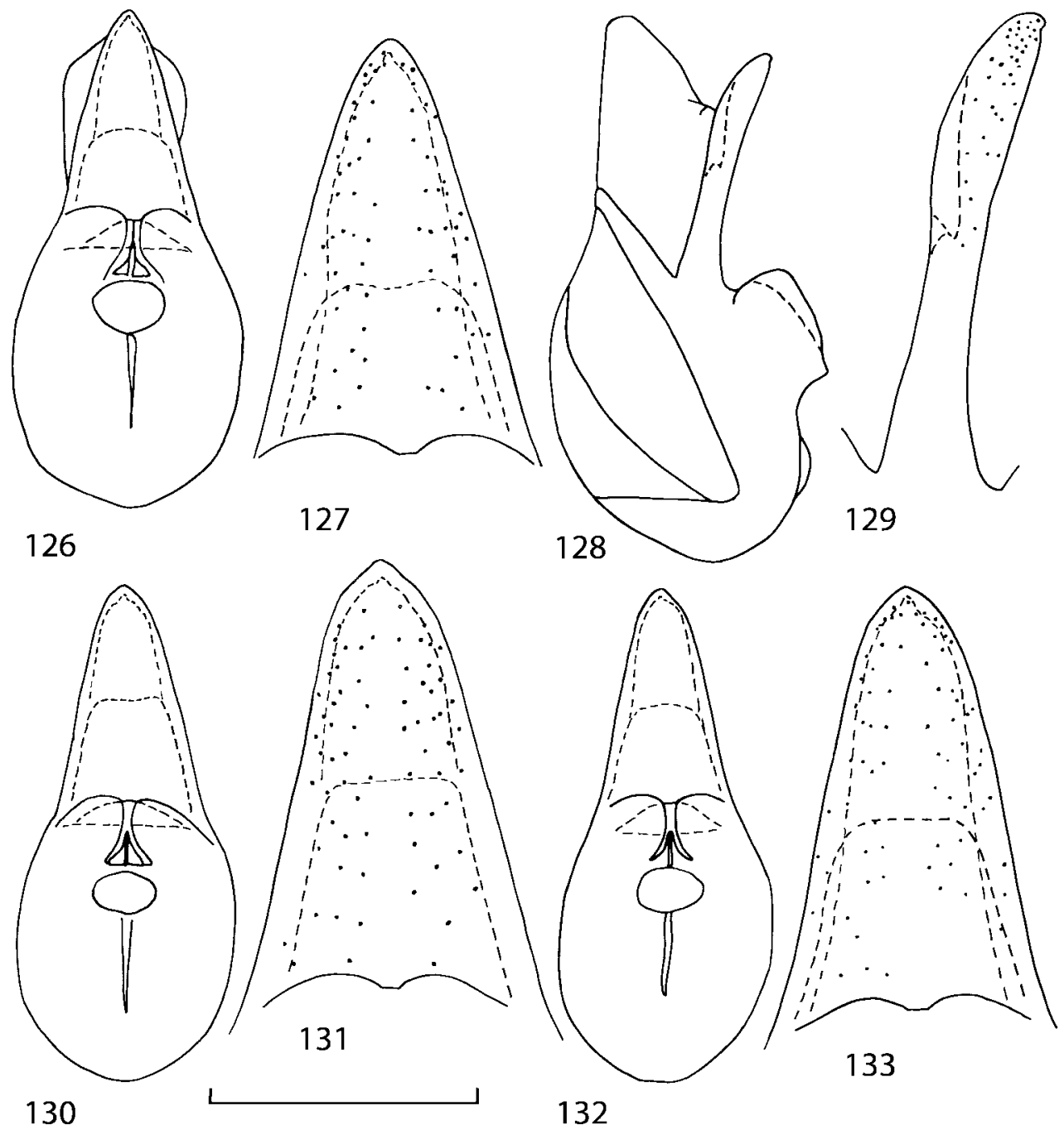

FIGURES 126-133. Aedeagus of Geostiba pluvigena Gusarov, sp. n. (paratypes from the junction of Blue Ridge Parkway and Balsam Mountain Road (126-129, 132-133) and Waterrock Knob (130131), North Carolina). 126, 130, 132 - median lobe, ventral view; 127, 131, 133 - apex of median lobe, ventral view; 128 - median lobe, lateral view; 129 - apex of median lobe, lateral view. Scale bar $0.2 \mathrm{~mm}(126,128,130,132), 0.1 \mathrm{~mm}(127,129,131,133)$. 
Diagnosis. Geostiba pluvigena can be distinguished from other Nearctic species of Geostiba by having small eyes (temple length to eye length ratio 2.7-3.8), pronotal pubescence of type $\mathrm{V}$, reduced wings, short elytra (pronotum length to elytron length ratio 1.3), the presence of two short parallel carinae in the middle of abdominal tergum 7 in front of posterior margin, the shape of the aedeagus (Figs. 126-138, 140-145) and the shape of the spermatheca (Fig. 139).

Geostiba pluvigena is closely related to G. nimbicola, G. nebuligena and G. crepusculigena. Geostiba pluvigena differs from G. nimbicola in having shorter and broader (in ventral view) apex of median lobe with weak apical denticle (in lateral view) (Figs. 126133, 100-107); from G. nebuligena in having weaker apical denticle of median lobe of aedeagus (Figs. 128-129, 155-156); from G. crepusculigena in lacking obtuse projection on the ventral side of the apex of median lobe (Figs. 128-129, 176-177).

Description. Length 1.9-2.2 mm. Brown, pronotum, elytra and apex of abdomen often lighter, antennae brownish yellow or light brown, legs and mouthparts brownish yellow. Body parallel-sided.

Head as wide as long, surface on disk with fine isodiametric microsculpture, puncturation very fine, distance between punctures equal to 3-4 times their diameter. Temple length to eye length ratio 2.7-3.8. Antennal article 2 longer than article 3, article 4 transverse (width to length ratio 1.6), articles 5-10 strongly transverse (ratio 1.7-1.9), last article as long as 9 and 10 combined (Fig. 17).

Pronotum as wide as long, width 0.36-0.43 mm, wider than head (pronotal width to head width ratio 1.1); microsculpture and puncturation as on head. Pronotal pubescence of type V. Elytra measured from humeral angle shorter than pronotum (pronotal length to elytral length ratio 1.3), wider than long (1.5), with fine isodiametric microsculpture and fine asperate puncturation, distance between punctures equals 2-3 times their diameter. Elytral suture behind scutellum slightly raised in both sexes. Wings reduced to short vestiges, shorter than elytra.

Abdominal terga with fine microsculpture of transverse meshes, with fine and sparse puncturation, puncturation becoming finer towards abdomen apex, on terga 3-5 distance between punctures equals 2-5 times their diameter. Tergum 7 without white edge.

Male tergum 7 with two medial carinae in front of posterior margin. Male tergum 8 with two or four weak and short carinae in front of posterior margin, posterior margin convex (Fig. 120). Male sternum 8 with convex posterior margin (Fig. 121).

Female tergum 8 with convex posterior margin (Fig. 122), sternum 8 with emarginate posterior margin (Figs. 123-124).

Aedeagus as in Figs. 126-138, 140-145. Apex of median lobe in ventral view narrow, its outline convex or doubly emarginate apically (Figs. 126-127, 130-133), in lateral view strait, with weak apical denticle ventrally (Figs. 128-129), distal diverticula of internal sac in ventral view broad (Figs. 137-138).

Spermatheca as in Fig. 139. 
Distribution. Known from the Plott Balsams - Cataloochee Divide massif (North Carolina) (Figs. 338, 340).

Natural History. Geostiba nimbicola was collected at altitudes above $1600 \mathrm{~m}$ in leaf litter in mixed forest with red spruce (Picea rubens).

Etymology. The specific name is derived from the Latin adjective pluvius (rainy) and the verb gigno (to be born, to arise). It refers to the rains in the Southern Appalachians where the species occurs.

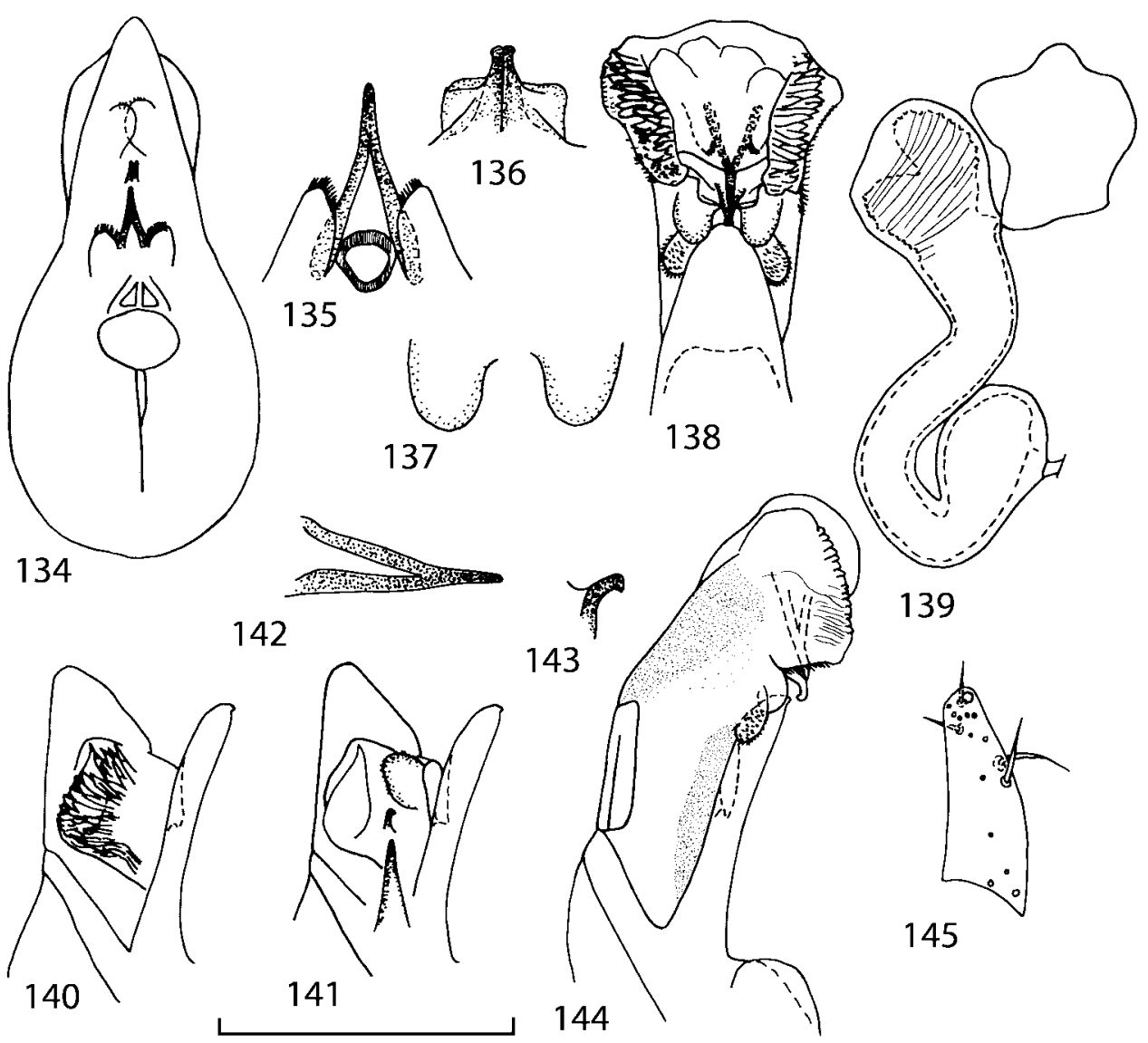

FIGURES 134-145. Genitalia of Geostiba pluvigena Gusarov, sp. n. (paratypes from the junction of Blue Ridge Parkway and Balsam Mountain Road (134, 139-141) and Waterrock Knob (135-138, 142-145), North Carolina). 134 - details of internal sac retracted into median lobe, ventral view; 135 - copulatory piece of internal sac, dorsal view; 136 - medial lamellae of internal sac, ventral view; 137 - distal diverticula of everted internal sac, ventral view; 138 - everted internal sac, ventral view; 139 - spermatheca; 140-141 - details of internal sac retracted into median lobe, lateral view; 142 - copulatory piece of internal sac, lateral view; 143 - medial lamella of internal sac, lateral view; 144 - everted internal sac, lateral view; 145 - apex of left paramere, side facing median lobe. Scale bar $0.2 \mathrm{~mm}(134,138,140-141,144), 0.1 \mathrm{~mm}(135-137,139,142-143,145)$. 
Type material. Holotype, ơ UNITED STATES: Tennessee / North Carolina: Sevier Co. / Swain Co.: Appalachian Scenic Trail W of Clingmans Dome, 16 km S Gatlinburg, $35^{\circ} 33.93 ' \mathrm{~N} 83^{\circ} 31.76 \mathrm{~W}, 1800 \mathrm{~m}$, in forest litter, Picea, Abies, Acer, Fraxinus, Oxalis (V.I.Gusarov), 22.vi.2001 (KSEM).

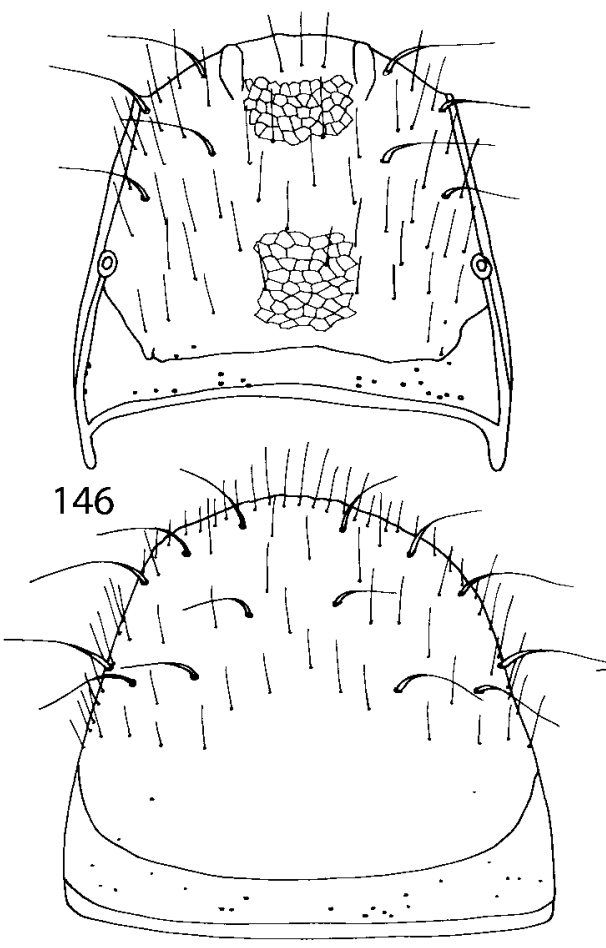

147

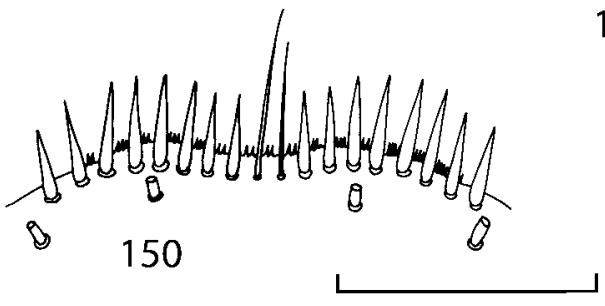

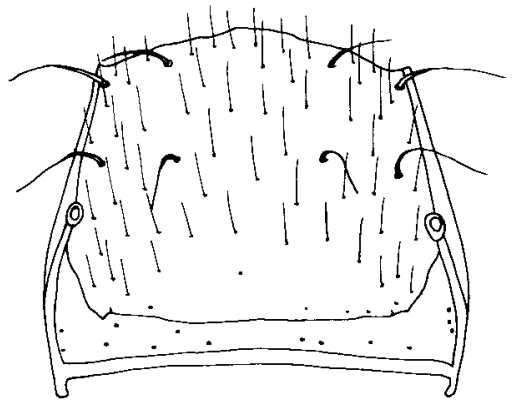

148

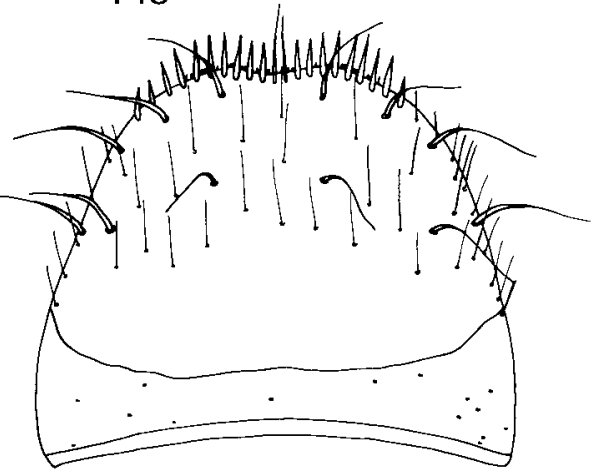

149

FIGURES 146-151. Abdominal segments 7-8 of Geostiba nebuligena Gusarov, sp. n. (paratypes from the Appalachian National Scenic Trail W of Clingmans Dome, Tennessee / North Carolina). 146 - male tergum $8 ; 147$ - male sternum $8 ; 148$ - female tergum $8 ; 149$ - female sternum 8,150 apex of female sternum $8 ; 151$ - medial portion of male tergum 7 , posterior down. Scale bar 0.2 $\mathrm{mm}(146-149,151), 0.1 \mathrm{~mm}(150)$.

Paratypes: UNITED STATES: Tennessee / North Carolina: Sevier Co. / Swain Co.: 49 specimens, same data as the holotype (KSEM, AMNH, CNCI, SPSU, FMNH); 27

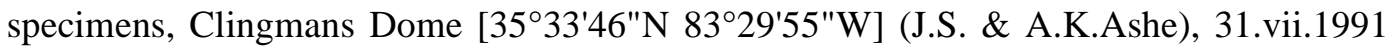


(KSEM); $20^{x} 0^{x}$, ditto but 2000 m, Fraser Fir - Red Spruce forest (J.Bengston), 7.vii.1974 (FMNH); 83 specimens, Clingmans Dome Road, 14 km SSE Gatlinburg, 35³5.46'N $83^{\circ} 28.28^{\prime} \mathrm{W}, 1800 \mathrm{~m}$, in forest litter, Picea rubens, Abies fraseri, Oxalis, Rubus (V.I.Gusarov), 1.vi.2001 (KSEM, SPSU); 19 specimens, Appalachian National Scenic Trail, W of Clingmans Dome, $16 \mathrm{~km} \mathrm{~S}$ Gatlinburg, $35^{\circ} 33.88^{\prime} \mathrm{N} 83^{\circ} 31.41^{\prime} \mathrm{W}, 1930 \mathrm{~m}$, in forest litter,

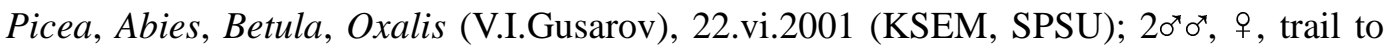
Mt. Le Conte from Newfound Gap (W.S.Suter), 29.v.1982 (KSEM); 24 specimens, $0.5 \mathrm{~km}$ E Newfound Gap, $13 \mathrm{~km}$ SE Gatlinburg, 35 $36.44^{\prime} \mathrm{N} 83^{\circ} 25.37^{\prime} \mathrm{W}, 1650 \mathrm{~m}$, in forest litter, Picea rubens, Oxalis, Vaccinium (V.I.Gusarov), 1.vi.2001 (KSEM, SPSU); Tennessee: Sevier Co.: 13 specimens, Highway 441 \& 71, $13 \mathrm{~km}$ SE Gatlinburg, 35 37.3' N $83^{\circ} 26.3^{\prime} \mathrm{W}, 1300 \mathrm{~m}$, in forest litter, Rhododendron, Tsuga, Betula (V.I.Gusarov), 22.vi.2001 (SPSU); $0^{x}$, ㅇ, descending the Chimney Tops, 9-10 km SSE Gatlinburg, $35^{\circ} 37.6-38.2^{\prime} \mathrm{N} 83^{\circ} 28.2^{\prime} \mathrm{W}, 1040-1200 \mathrm{~m}$, in forest litter, Tsuga, Acer, Rhododendron (V.I.Gusarov), 22.vi.2001 (SPSU); $0^{x}$, Great Smokey Mts. National Park (W.Shear \& F.Coyle), 24.x.1969 (FMNH); 18 specimens, Mt. Le Conte, half way up [35 38.5'N $8^{\circ} 26.8^{\prime} \mathrm{W}$, deciduous forest, dry leaf litter near log (Lackey), 5.viii.1956 (FMNH, SPSU); North Carolina: Swain Co.: $0^{\star}$, 오, S slope of Clingmans Dome, $19 \mathrm{~km} \mathrm{NW}$ Cherokee, $35^{\circ} 33.66^{\prime} \mathrm{N} 83^{\circ} 29.9^{\prime} \mathrm{W}, 2000 \mathrm{~m}$, in forest litter, under young Abies trees (V.I.Gusarov), 1.vi.2001 (SPSU);

Mislabeled material. 14 specimens, UNITED STATES: Michigan, Gogebic Co., Ottawa National Forest, Sylvania Tract, litter \& mycelium (J.Wagner), 13.viii.1977 (KSEM). These specimens are identical with the types of G. nebuligena in all external characters and in genitalia. G. nebuligena is a wingless species restricted to the Great Smoky Mountains massif in the Southern Appalachians, and it is impossible for this species to occur also in Michigan, the area which was covered by ice sheet in Pleistocene. I consider these 14 specimens as mislabeled and exclude them from the types series, because their origin is unknown. Geostiba nebuligena does not occur in Michigan.

Diagnosis. Geostiba nebuligena can be distinguished from other Nearctic species of Geostiba by having small eyes (temple length to eye length ratio 2.9-4.0), pronotal pubescence of type $\mathrm{V}$, reduced wings, short elytra (pronotum length to elytron length ratio 1.3), the presence of two short parallel carinae in the middle of abdominal tergum 7 in front of posterior margin and the shape of the aedeagus (Figs. 152-161, 163-168) and the shape of the spermatheca (Fig. 162).

Geostiba nebuligena differs from closely related G. nimbicola, G. pluvigena and G. crepusculigena in having apex of median lobe with strong apical denticle (in lateral view) (Figs. 155-156, 102-103, 128-129, 176-177).

Description. Length 1.6-1.9 mm. Light brown to brown, antennae light brown, legs and mouthparts brownish yellow. Body parallel-sided.

Head as wide as long, surface on disk with fine isodiametric microsculpture, puncturation very fine, distance between punctures equal to 3-4 times their diameter. Temple 

verse (width to length ratio 1.6), articles 5-10 strongly transverse, last article as long as 9 and 10 combined (as in Fig. 17).

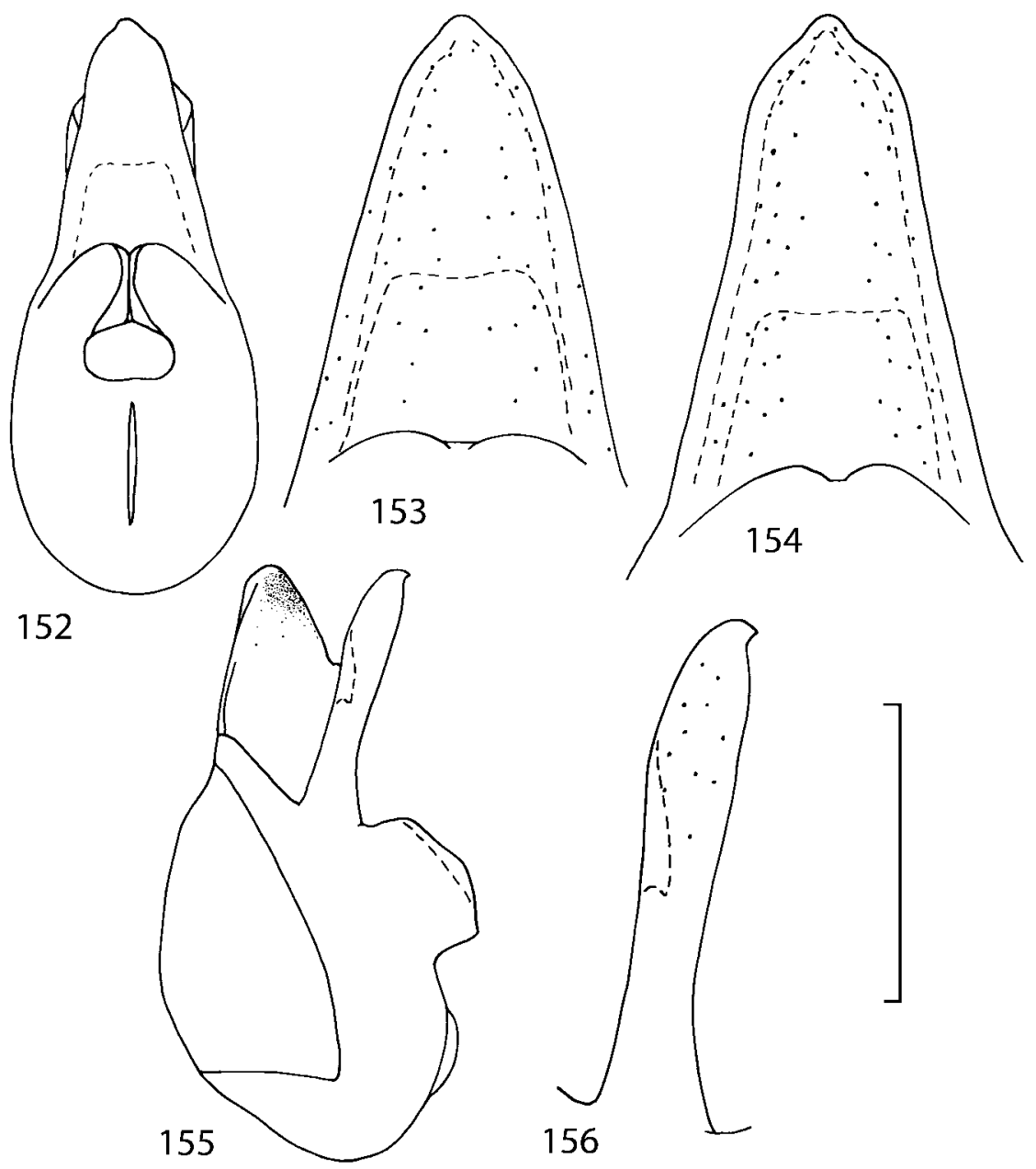

FIGURES 152-156. Aedeagus of Geostiba nebuligena Gusarov, sp. n. (paratypes from Highways $441 \& 71$, Tennessee $(152,154-156)$ and Appalachian National Scenic Trail W of Clingmans Dome (153), Tennessee / North Carolina). 152 - median lobe, ventral view; 153-154 - apex of median lobe, ventral view; 155 - median lobe, lateral view; 156 - apex of median lobe, lateral view. Scale bar $0.2 \mathrm{~mm}(152,155), 0.1 \mathrm{~mm}(153-154,156)$.

Pronotum as wide as long, width $0.37-0.40 \mathrm{~mm}$, wider than head (pronotal width to head width ratio 1.2); microsculpture and puncturation as on head. Pronotal pubescence of type V. Elytra measured from humeral angle shorter than pronotum (pronotal length to elytral length ratio 1.3), wider than long (1.5), with fine isodiametric microsculpture and fine asperate puncturation, distance between punctures equals 2-3 times their diameter. 
Elytral suture behind scutellum slightly raised in both sexes. Wings reduced to short vestiges, shorter than elytra.

Abdominal terga with fine microsculpture of transverse meshes, with fine and sparse puncturation, puncturation becoming finer towards abdomen apex, on terga 3-5 distance between punctures equals 3-6 times their diameter. Tergum 7 without white edge.

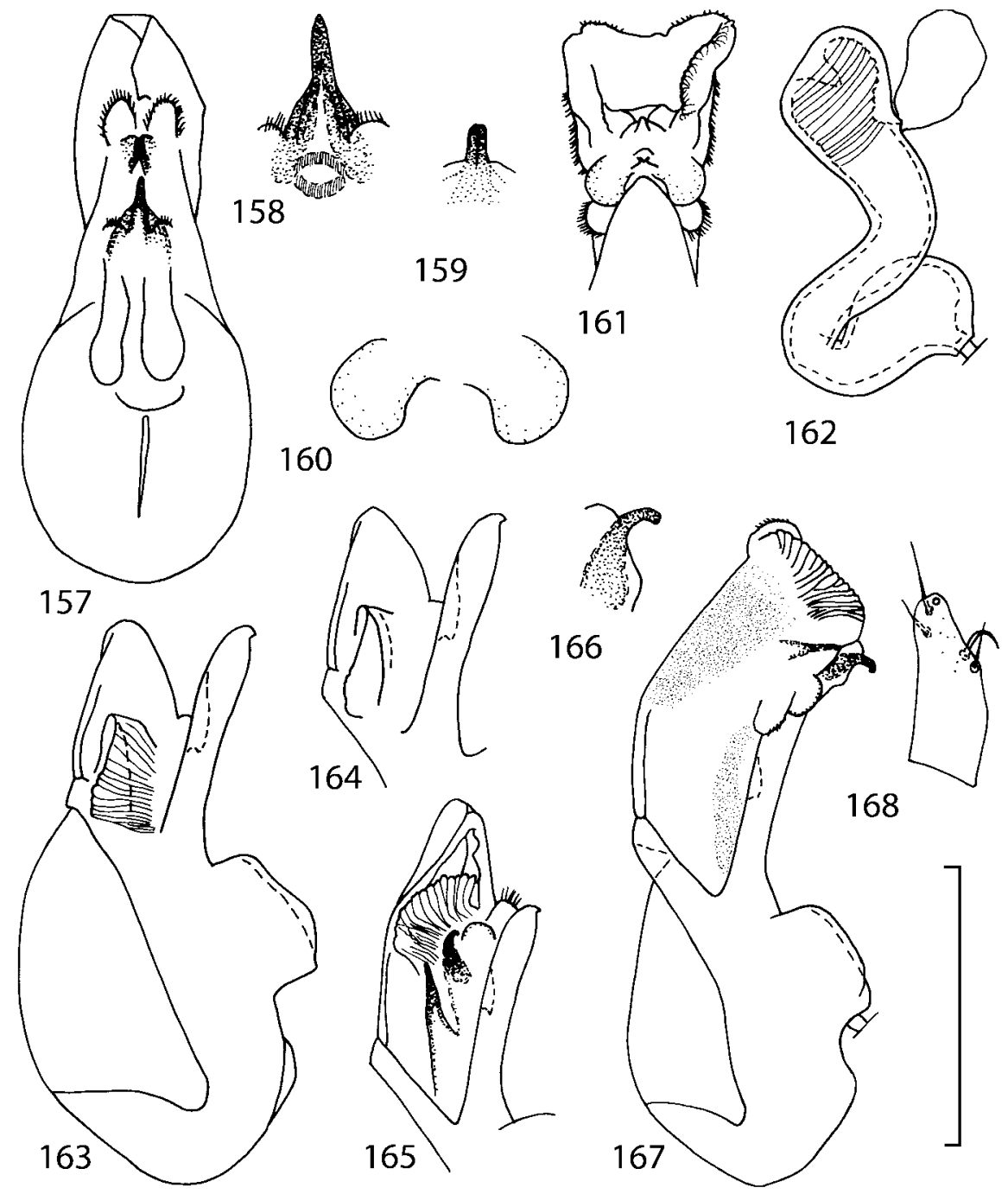

FIGURES 157-168. Genitalia of Geostiba nebuligena Gusarov, sp. n. (paratypes from Appalachian National Scenic Trail W of Clingmans Dome (157-162, 165-168), Tennessee / North Carolina and Highways 441 \& 71, Tennessee (163-164)). 157 - details of internal sac retracted into median lobe, ventral view; 158 - copulatory piece of internal sac, dorsal view; 159 - medial lamellae of internal sac, ventral view; 160 - distal diverticula of everted internal sac, ventral view; 161 everted internal sac, ventral view; 162 - spermatheca; 163-164 - details of internal sac retracted into median lobe, lateral view; 165 - details of slightly everted internal sac, lateral view; 166 medial lamella of internal sac, lateral view; 167 - everted internal sac, lateral view; 168 - apex of left paramere, side facing median lobe. Scale bar $0.2 \mathrm{~mm}(157,161,163-165,167), 0.1 \mathrm{~mm}(158-$ $160,162,166,168)$ 
Male tergum 7 with two medial carinae in front of posterior margin. Male tergum 8 with two weak and short carinae in front of posterior margin, posterior margin convex (Fig. 146). Male sternum 8 with convex posterior margin (Fig. 147).

Female tergum 8 with convex posterior margin (Fig. 148), sternum 8 with weakly emarginate posterior margin (Figs. 149-150).

Aedeagus as in Figs. 152-161, 163-168. Apex of median lobe in ventral view narrow, its outline doubly emarginate apically (Figs. 152-154), in lateral view strait, with strong apical denticle ventrally (Figs. 155-156), distal diverticula of internal sac in ventral view broad (Figs. 160-161).

Spermatheca as in Fig. 162.

Distribution. Known from the Great Smoky Mountains massif (Tennessee and North Carolina) (Figs. 338, 340).

Natural History. Geostiba nebuligena was collected at altitudes above $1000 \mathrm{~m}$ in leaf litter in pure conifer or mixed forest with red spruce (Picea rubens), Fraser's fir (Abies fraseri) or hemlock.

Etymology. The specific name is derived from the Latin noun nebula (mist, fog) and the verb gigno (to be born, to arise). It refers to fogs in the Great Smoky Mountains where the species occurs.

\section{Geostiba (Sibiota) crepusculigena Gusarov, sp. n. (Figs. 169-186)}

Type material. Holotype, $\sigma^{x}$, UNITED STATES: Tennessee: Cocke Co.: Snake Den Ridge Trail, $9 \mathrm{~km} \mathrm{~S}$ Cosby, $35^{\circ} 44.18^{\prime} \mathrm{N} 83^{\circ} 14.60^{\prime} \mathrm{W}, 1520 \mathrm{~m}$, in forest litter, Picea, Rhododendron, Betula (V.I.Gusarov), 23.ix.2001 (KSEM).

Paratypes: UNITED STATES: Tennessee: Cocke Co.: 20 specimens, same data as the holotype; 10 specimens, ditto but $8 \mathrm{~km} \mathrm{~S}$ Cosby, $35^{\circ} 44.61^{\prime} \mathrm{N} 83^{\circ} 14.00^{\prime} \mathrm{W}, 1470 \mathrm{~m}$, Tsuga, Picea, Rhododendron, Betula (all - KSEM, SPSU).

Diagnosis. Geostiba crepusculigena can be distinguished from other Nearctic species of Geostiba by having small eyes (temple length to eye length ratio 3.0-3.1), pronotal pubescence of type $\mathrm{V}$, reduced wings, short elytra (pronotum length to elytron length ratio 1.3), the presence of two short parallel carinae in the middle of abdominal tergum 7 in front of posterior margin, the shape of the aedeagus (Figs. 174-180, 182-186) and the shape of the spermatheca (Fig. 181).

Geostiba crepusculigena differs from closely related G. nimbicola, G. pluvigena and G. nebuligena in having apex of median lobe with obtuse apical projection (in lateral view) (Figs. 176-177, 102-103, 128-129, 155-156).

Description. Length 1.8-2.3 mm. Body brown to dark brown, antennae brown, legs and mouthparts brownish yellow. Body parallel-sided.

Head as wide as long, surface on disk with fine isodiametric microsculpture, puncturation very fine, distance between punctures equal to 3-4 times their diameter. Temple 
length to eye length ratio 3.0-3.1. Antennal article 2 longer than article 3, article 4 transverse (width to length ratio 1.6), articles 5-10 strongly transverse, last article as long as 9 and 10 combined (as in Fig. 17).

Pronotum as wide as long, width $0.34-0.40 \mathrm{~mm}$, wider than head (pronotal width to head width ratio 1.1); microsculpture and puncturation as on head. Pronotal pubescence of type V. Elytra measured from humeral angle shorter than pronotum (pronotal length to elytral length ratio 1.3), wider than long (1.5), with fine isodiametric microsculpture and fine asperate puncturation, distance between punctures equals 1-3 times their diameter. Elytral suture behind scutellum slightly raised in both sexes. Wings reduced to short vestiges, shorter than elytra.

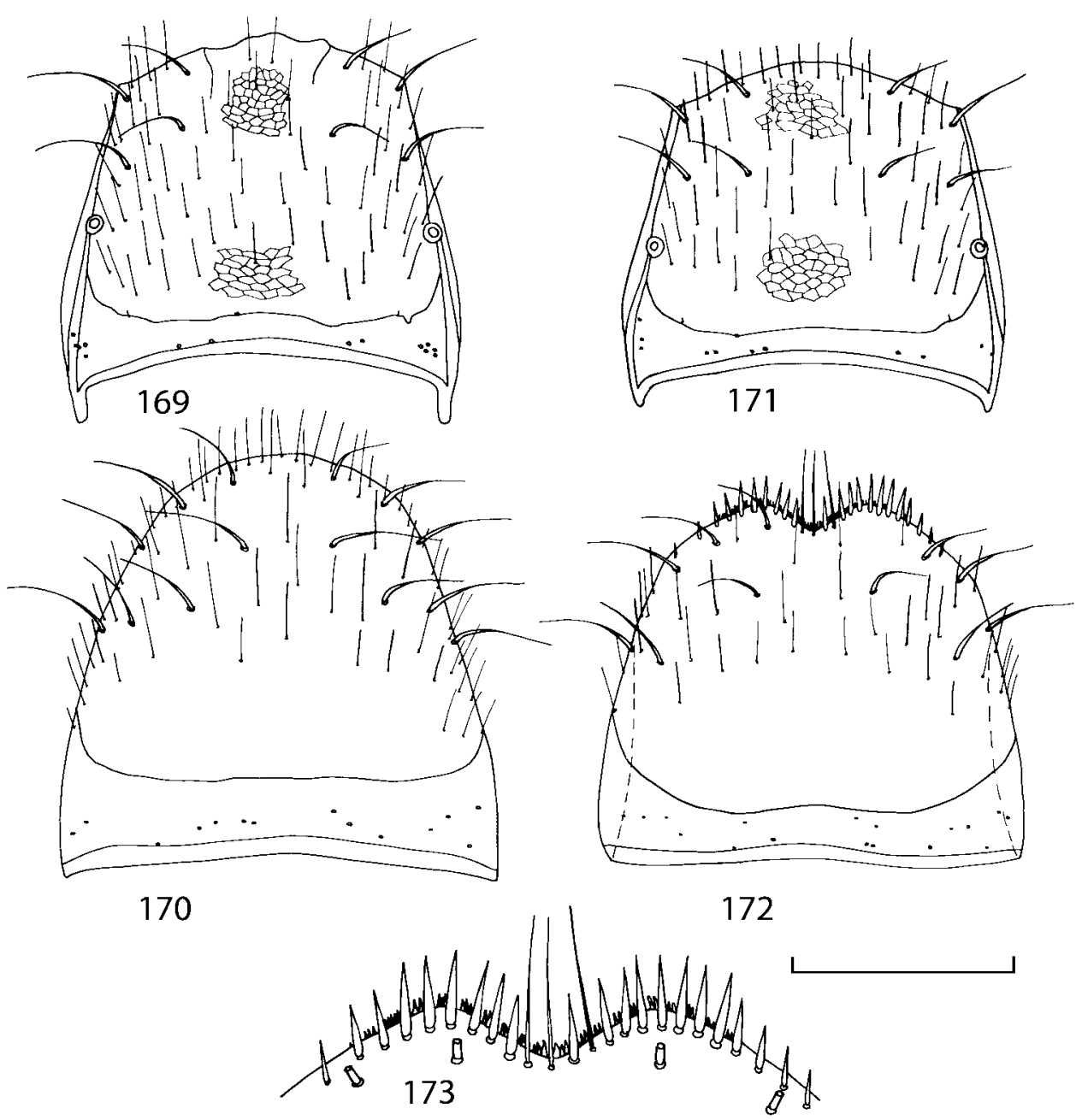

FIGURES 169-173. Abdominal segment 8 of Geostiba crepusculigena Gusarov, sp. n. (paratypes from Snake Ridge Trail, Tennessee). 169 - male tergum 8; 170 - male sternum 8; 171 - female tergum $8 ; 172$ - female sternum 8, 173 - apex of female sternum 8. Scale bar 0.2 mm (169-172), 0.1 mm (173). 
Abdominal terga with fine microsculpture of transverse meshes, with fine and sparse puncturation, puncturation becoming finer towards abdomen apex, on terga 3-5 distance between punctures equals 2-6 times their diameter. Tergum 7 without white edge.

Male tergum 7 with two medial carinae in front of posterior margin. Male tergum 8 with two or four weak and short carinae in front of posterior margin, posterior margin convex (Fig. 169). Male sternum 8 with convex posterior margin (Fig. 170).

Female tergum 8 with convex posterior margin (Fig. 171), sternum 8 with strongly emarginate posterior margin (Figs. 172-173).

Aedeagus as in Figs. 174-180, 182-186. Apex of median lobe in ventral view narrow, its outline convex apically (Figs. 174-175), in lateral view strait, with strong obtuse apical projection ventrally (Figs. 176-177), distal diverticula of internal sac in ventral view broad (Figs. 179-180).

Spermatheca as in Fig. 181.

Distribution. Known from Snake Den Mountain in the Great Smoky Mountains massif (Tennessee) (Figs. 338, 340).

Natural History. Geostiba nebuligena was collected at altitudes of $1400-1600 \mathrm{~m}$ in leaf litter in mixed forest with red spruce (Picea rubens), birch, purple laurel (Rhododendron catawbiense) and hemlock.

Etymology. The specific name is derived from the Latin noun crepusculum (dusk, twilight) and the verb gigno (to be born, to arise). It refers to the dark forests in the Great Smoky Mountains where the species occurs.

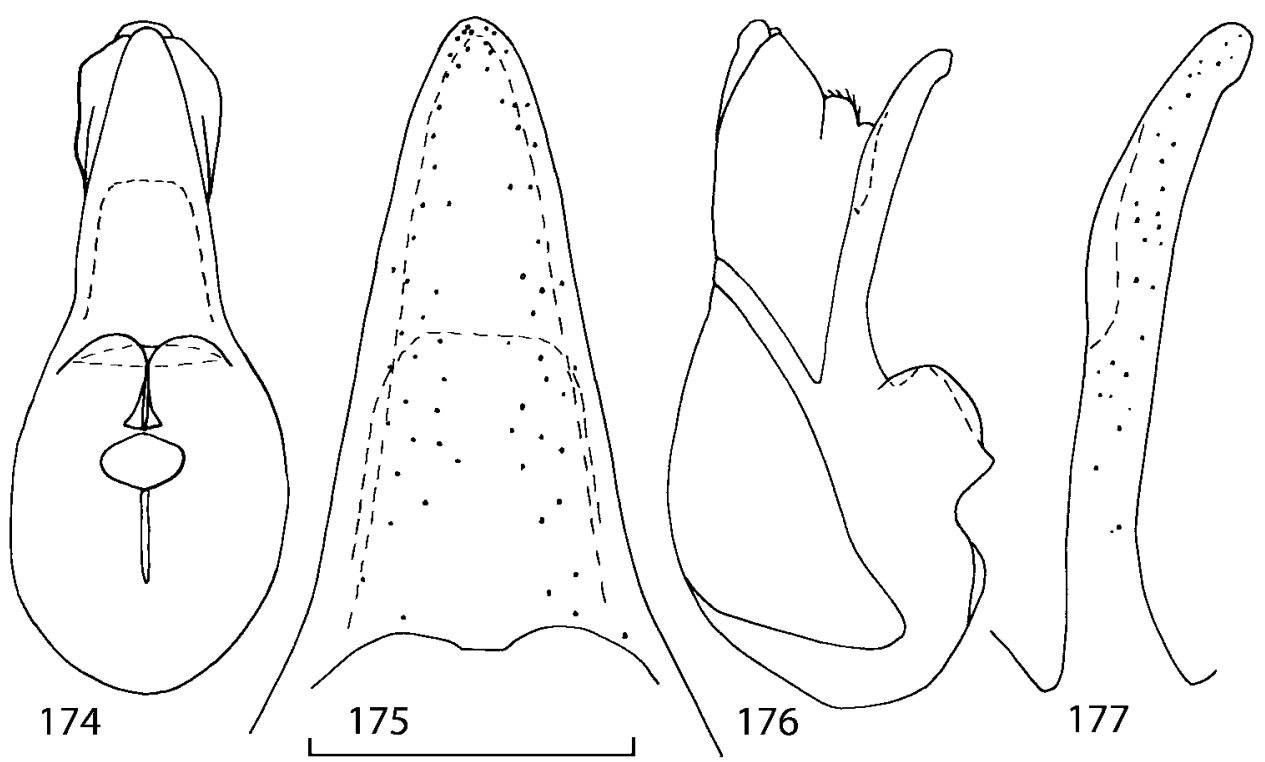

FIGURES 174-177. Aedeagus of Geostiba crepusculigena Gusarov, sp. n. (paratype from Snake Ridge Trail, Tennessee). 174 - median lobe, ventral view; 175 - apex of median lobe, ventral view; 176 - median lobe, lateral view; 177 - apex of median lobe, lateral view. Scale bar $0.2 \mathrm{~mm}$ (174, 176), $0.1 \mathrm{~mm}(175,177)$. 

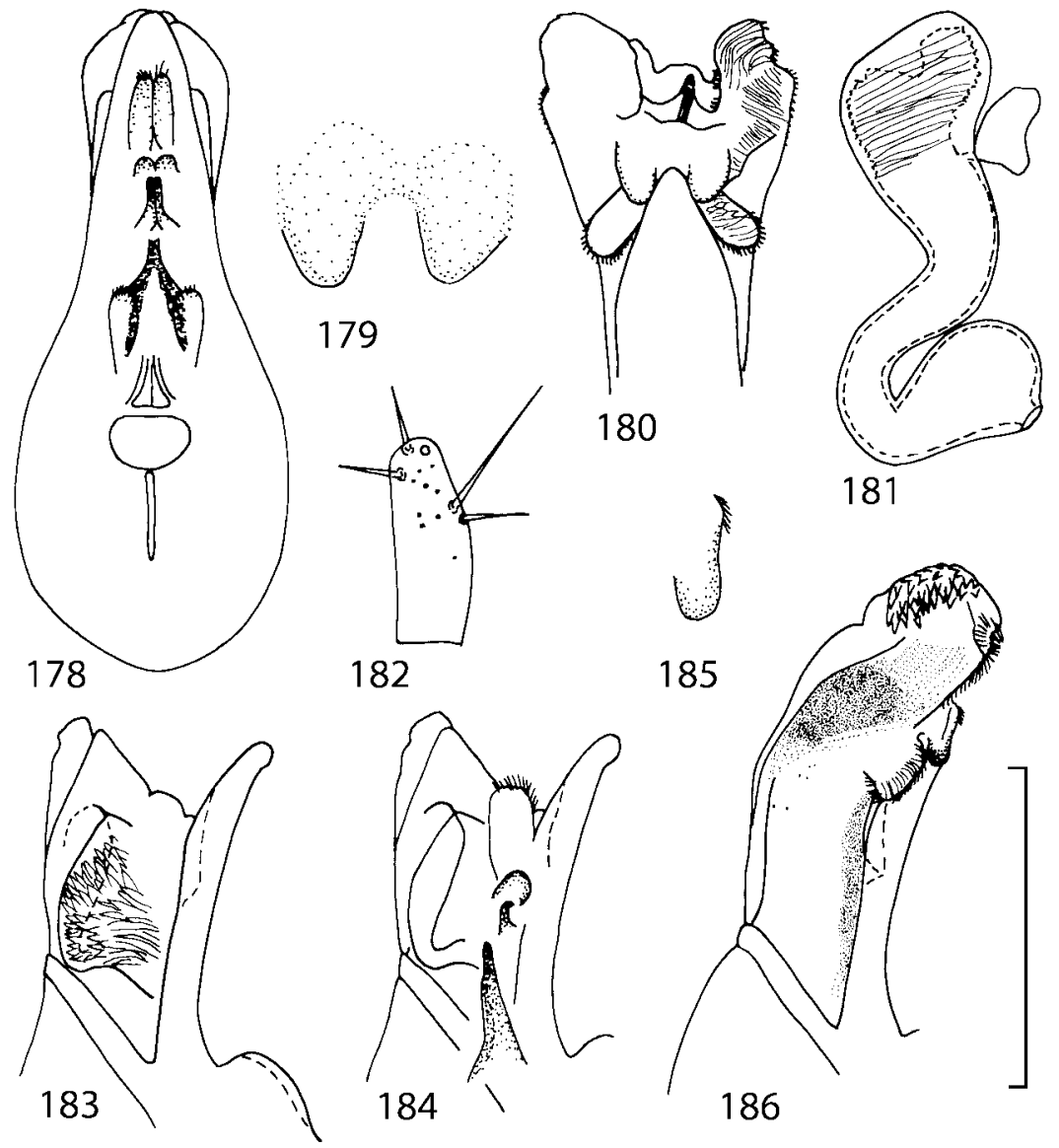

181

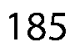

185

FIGURES 178-186. Genitalia of Geostiba crepusculigena Gusarov, sp. n. (paratypes from Snake Ridge Trail, Tennessee). 178 - details of internal sac retracted into median lobe, ventral view; 179 - distal diverticula of everted internal sac, ventral view; 180 - everted internal sac, ventral view; 181 - spermatheca; 182 - apex of left paramere, side facing median lobe; 183-184 - details of internal sac retracted into median lobe, lateral view; 185 - right distal diverticulum of everted internal sac, lateral view; 186 - everted internal sac, lateral view. Scale bar $0.2 \mathrm{~mm}$ (178, 180, 183-184, 186), $0.1 \mathrm{~mm}(179,181-182,185)$.

\section{Geostiba (Sibiota) balsamensis Pace, 1997 (Figs. 187-212)}

Geostiba (Lioglutosipalia) balsamensis Pace, 1997: 104.

Material. UNITED STATES: North Carolina: Swain Co.: 8 specimens, SW slope of Cataloochee Balsam Mt., Balsam Mt. Road, $20 \mathrm{~km}$ NW Waynesville, 35³4.3' N $83^{\circ} 10.9^{\prime} \mathrm{W}, 1700 \mathrm{~m}$, in forest litter, Picea rubens, Acer, Fagus, Betula (V.I.Gusarov), 2.vi.2001; 3 specimens, Balsam Mt. Road, 17 km NWW Waynesville, $35^{\circ} 32.79^{\prime} \mathrm{N}$ $83^{\circ} 10.0^{\prime} \mathrm{W}, 1650 \mathrm{~m}$, in forest litter, Picea rubens, Abies fraseri, Fagus, Betula (V.I.Gusarov), 2.vi.2001; Swain Co. / Haywood Co.: 2 specimens, Balsam Mt. Road, Masonic 
Monument, $17 \mathrm{~km}$ NWW Waynesville, $35^{\circ} 32.2^{\prime} \mathrm{N} 83^{\circ} 10.2^{\prime} \mathrm{W}, 1400 \mathrm{~m}$, in forest litter, Tsuga, Acer, Rhododendron (V.I.Gusarov), 2.vi.2001; Haywood Co. / Jackson Co.: 5 specimens, junction of Balsam Mt. Road and Blue Ridge Parkway, $17 \mathrm{~km}$ W Waynesville, $35^{\circ} 29.72 ' \mathrm{~N} 83^{\circ} 10.43^{\prime} \mathrm{W}, 1600 \mathrm{~m}$, in forest litter, Picea rubens, Fagus, Betula, Rhododendron (V.I.Gusarov), 2.vi.2001 (all in KSEM); ${ }^{x}$, N slope of Waterrock Knob, 13 km W Waynesville, $35^{\circ} 28.0^{\prime} \mathrm{N} 83^{\circ} 08.2^{\prime} \mathrm{W}, 1900 \mathrm{~m}$, in forest litter, Picea rubens, Abies fraseri (V.I.Gusarov), 2.vi.2001 (SPSU); Haywood Co.: ơ $^{x}$ Blue Ridge Parkway, $15 \mathrm{~km} \mathrm{~W}$ Waynesville, $35^{\circ} 30.34^{\prime} \mathrm{N} \mathrm{83} 09.34^{\prime} \mathrm{W}, 1350 \mathrm{~m}$, in forest litter (V.I.Gusarov), 20.viii.1998 (SPSU).
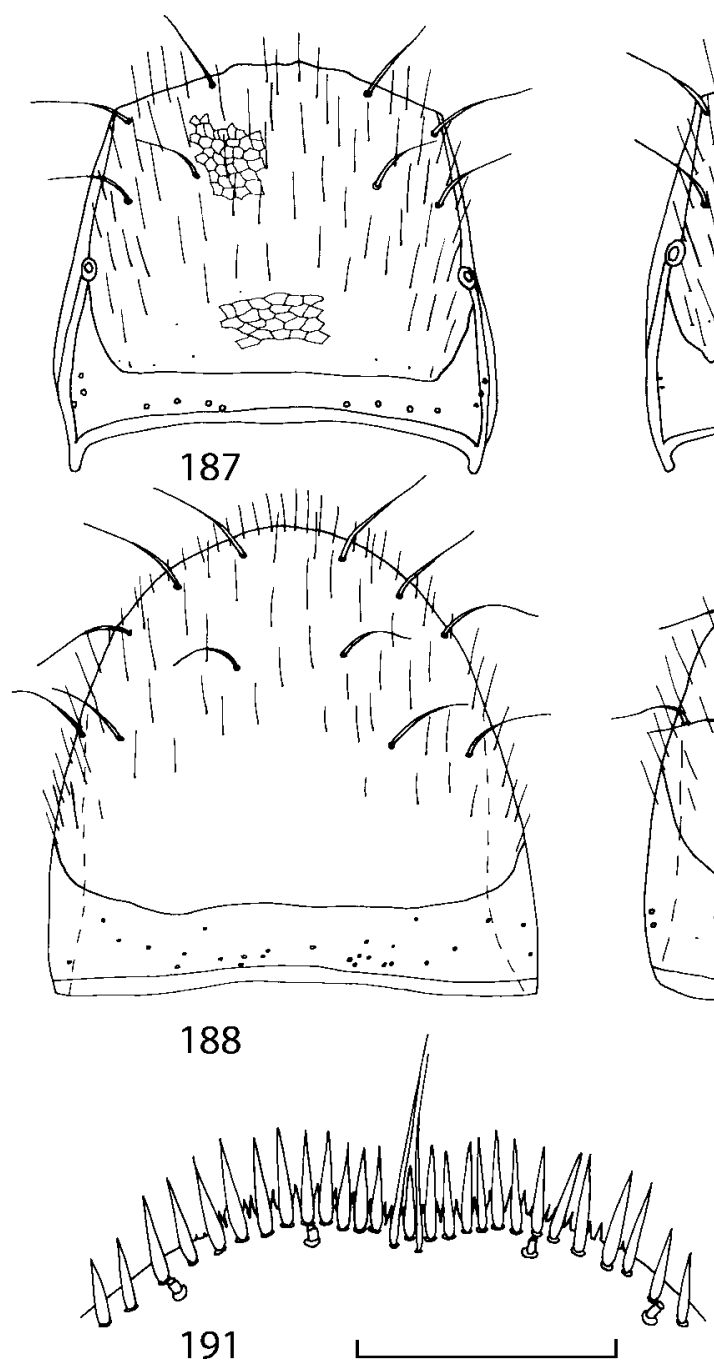

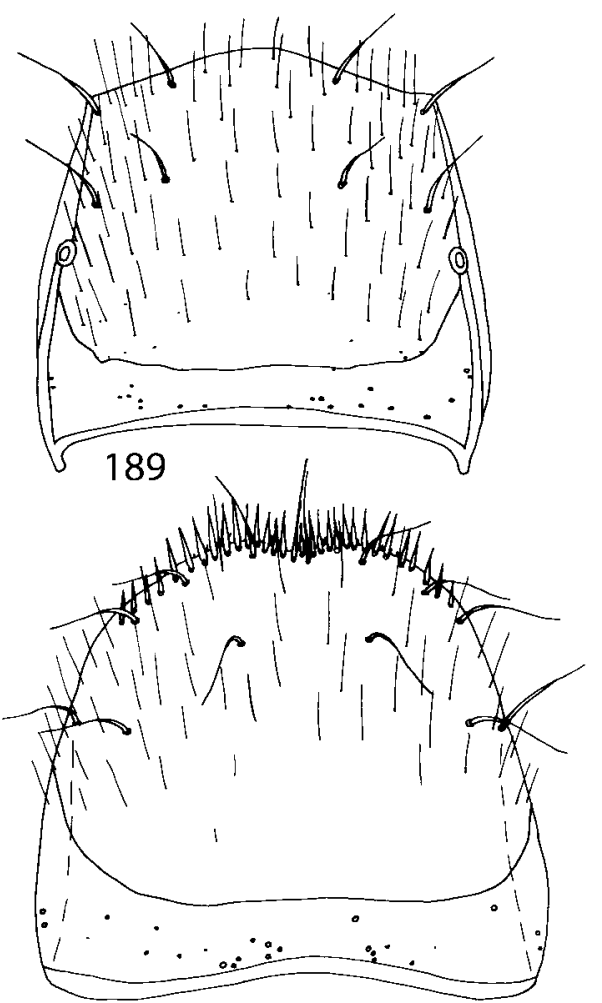

190

FIGURES 187-192. Abdominal segments 7-8 of Geostiba balsamensis Pace (Cataloochee Balsam Mountain, North Carolina). 187 - male tergum 8; 188 - male sternum 8; 189 - female tergum 8; 190 - female sternum 8, 191 - apex of female sternum 8; 192 - medial portion of male tergum 7 , posterior down. Scale bar $0.2 \mathrm{~mm}(187-190,192), 0.1 \mathrm{~mm}(191)$. 
Type locality. UNITED STATES: North Carolina: Swain Co.: Cataloochee Balsam Mt., Heintooga overlook (Pace 1997). Pace cites this locality as "Heintoge Overlot". This is one of the parking overlooks at the Heintooga spur of the Blue Ridge Parkway (Balsam Mountain Road).

Diagnosis. Geostiba balsamensis can be distinguished from other Nearctic species of Geostiba by having small eyes (temple length to eye length ratio 3.0-3.7), pronotal pubescence of type V, reduced wings, short elytra (pronotum length to elytron length ratio 1.4), the presence of two weak and short parallel carinae in the middle of abdominal tergum 7 in front of posterior margin, the shape of the aedeagus (Figs. 193-202, 204-212) and the shape of the spermatheca (Fig. 203).

Geostiba balsamensis differs from G. nubigena in having two week carinae on male tergum 7 and wider apex of median lobe (Figs. 193-194, 219-220, 223-229).

Description. Length $1.8-2.2 \mathrm{~mm}$. Body and antennae brownish yellow to light brown, legs and mouthparts brownish yellow. Body parallel-sided.

Head as wide as long, surface on disk with fine isodiametric microsculpture, puncturation very fine, distance between punctures equal to 2-4 times their diameter. Temple length to eye length ratio 3.0-3.8. Antennal article 2 longer than article 3, articles 4-10 transverse to strongly transverse, last article as long as 9 and 10 combined.

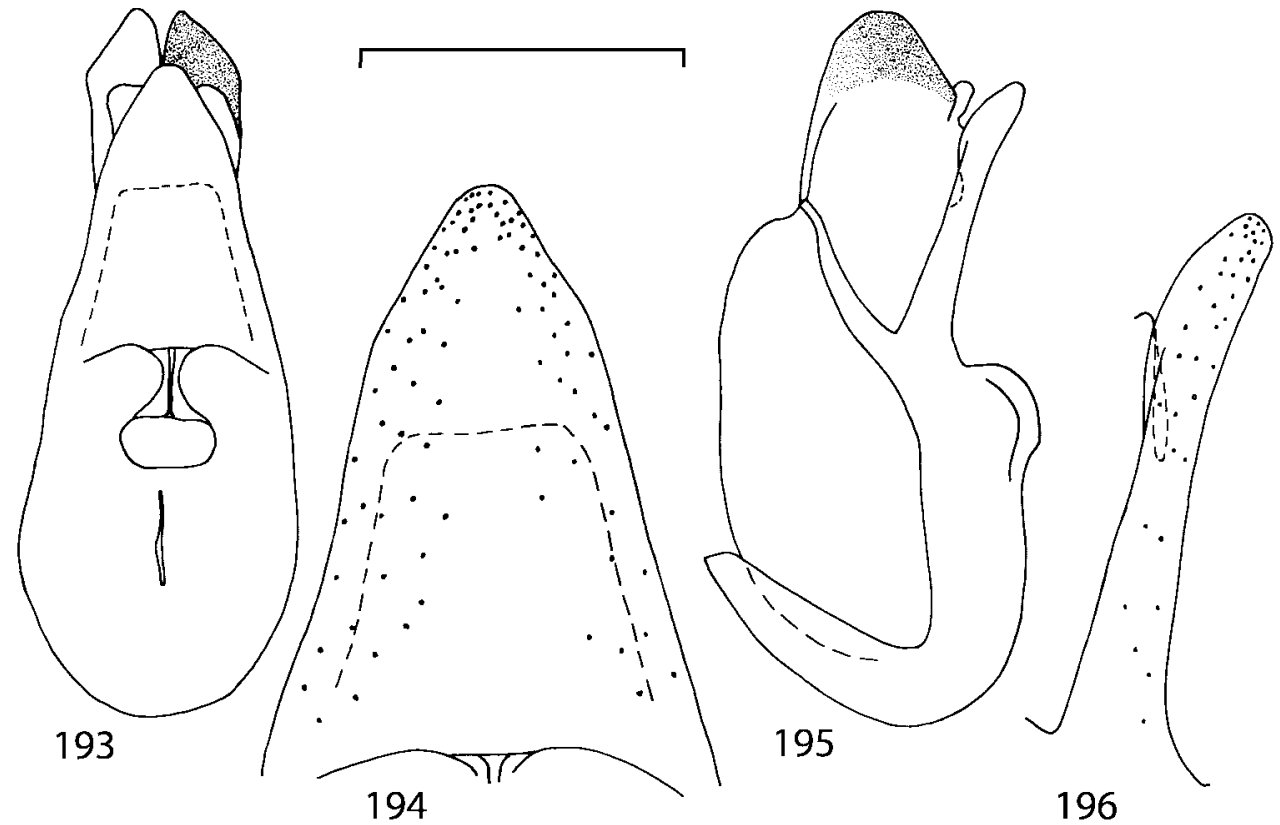

FIGURES 193-196. Aedeagus of Geostiba balsamensis Pace (Cataloochee Balsam Mountain, North Carolina). 193 - median lobe, ventral view; 194 - apex of median lobe, ventral view; 195 median lobe, lateral view; 196 - apex of median lobe, lateral view. Scale bar $0.2 \mathrm{~mm}(193,195)$, $0.1 \mathrm{~mm}(194,196)$. 
Pronotum as wide as long, width $0.36-0.39 \mathrm{~mm}$, wider than head (pronotal width to head width ratio 1.1); microsculpture and puncturation as on head. Pronotal pubescence of type V. Elytra measured from humeral angle shorter than pronotum (pronotal length to elytral length ratio 1.4), wider than long (1.6), with fine isodiametric microsculpture and fine asperate puncturation, distance between punctures equals 2-3 times their diameter. Elytral suture behind scutellum slightly raised in both sexes. Wings reduced to short vestiges, shorter than elytra.

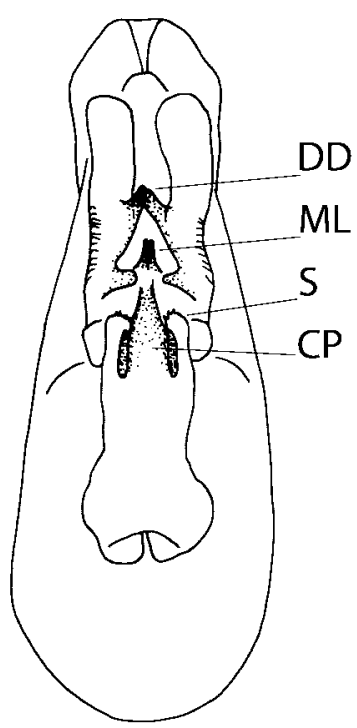

197

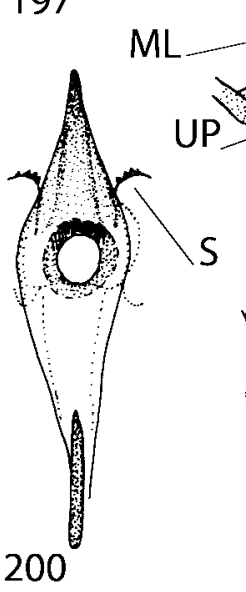

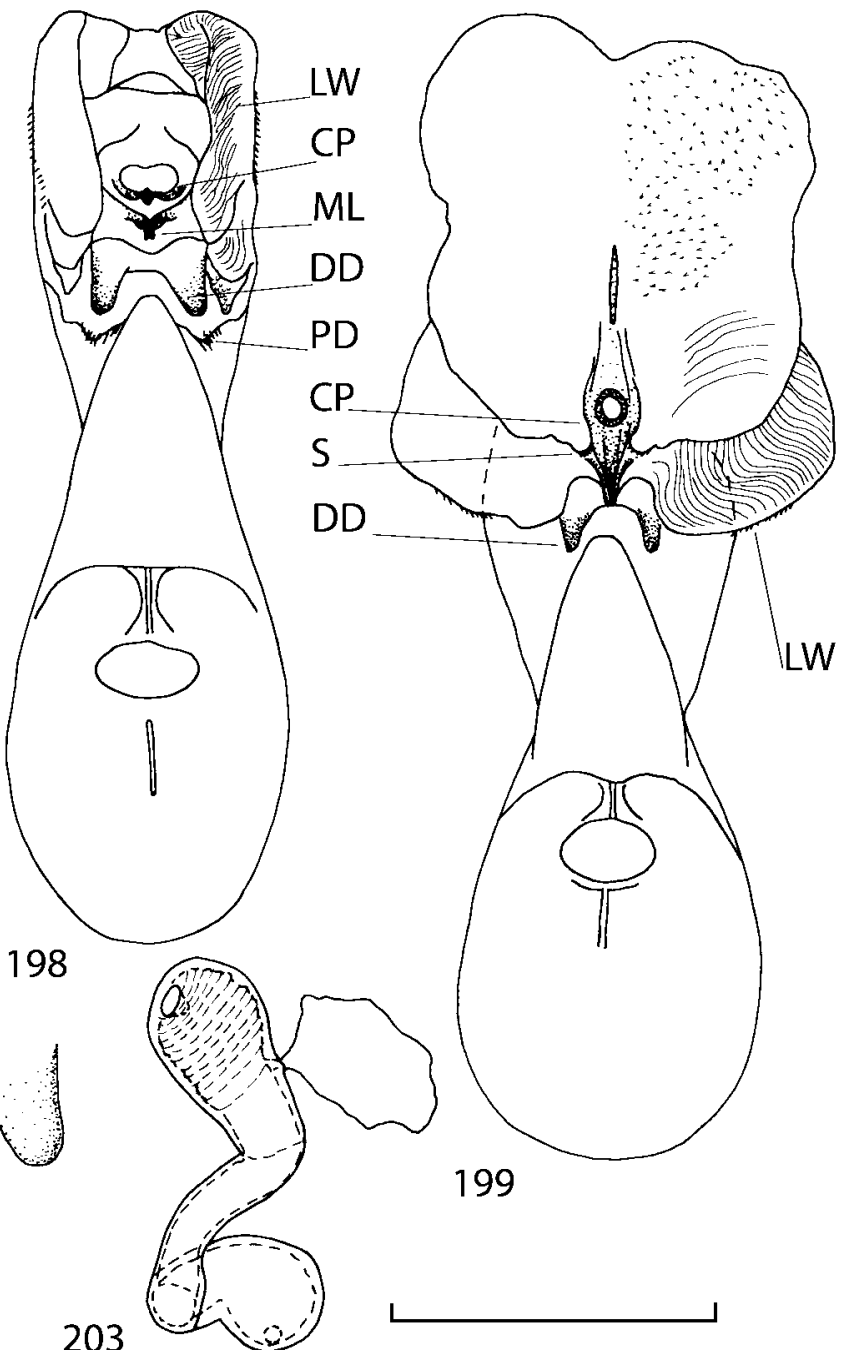

FIGURES 197-203. Genitalia of Geostiba balsamensis Pace (Cataloochee Balsam Mountain, North Carolina). 197 - details of internal sac retracted into median lobe, ventral view; 198 everted internal sac, ventral view; 199 - completely everted internal sac, ventral view; 200 - copulatory piece of internal sac, dorsal view; 201 - medial lamellae of internal sac, ventral view; 202 distal diverticula of everted internal sac, ventral view; 203 - spermatheca. Scale bar $0.2 \mathrm{~mm}$ (197199), $0.1 \mathrm{~mm}$ (200-203). CP - copulatory piece, DD - distal diverticula of internal sac, LW - lateral wall of internal sac, ML - medial lamellae, PD - proximal diverticula of internal sac, $\mathrm{S}$ - suspensoria, UP - U-shaped plate. 
Abdominal terga with fine microsculpture of transverse meshes, with fine and sparse puncturation, puncturation becoming finer towards abdomen apex, on terga 3-5 distance between punctures equals 3-6 times their diameter. Tergum 7 without white edge.

Male tergum 7 with two very weak medial carinae in front of posterior margin. Posterior margin of male tergum 8 and sternum 8 convex (Figs. 187-188).

Female tergum 8 with convex posterior margin (Fig. 189), posterior margin of female sternum 8 concave medially (Figs. 190-191).

Aedeagus as in Figs. 193-202, 204-212. Apex of median lobe in ventral view broad (Figs. 193-194), in lateral view strait (Figs. 195-196).

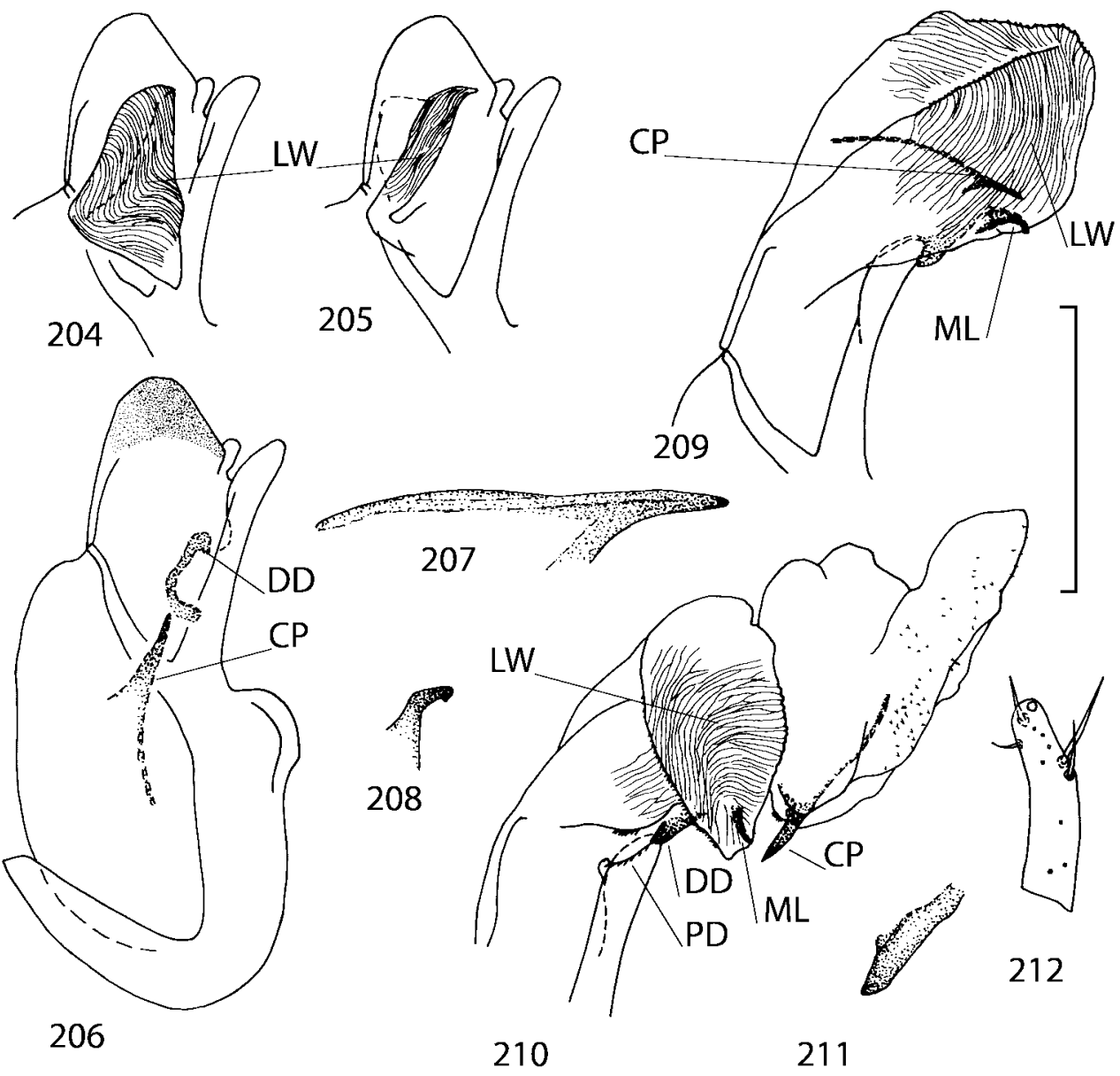

FIGURES 204-212. Aedeagus of Geostiba balsamensis Pace (Cataloochee Balsam Mountain, North Carolina). 204-206 - details of internal sac retracted into median lobe, lateral view; 207 copulatory piece of internal sac, lateral view; 208 - medial lamella of internal sac, lateral view; 209 - everted internal sac, lateral view; 210 - completely everted internal sac, lateral view; 211 - right distal diverticulum of everted internal sac, lateral view; 212 - apex of left paramere, side facing median lobe. Scale bar $0.2 \mathrm{~mm}$ (204-206, 209-210), $0.1 \mathrm{~mm}$ (207-208, 211-212).

$\mathrm{CP}$ - copulatory piece, DD - distal diverticula of internal sac, LW - lateral wall of internal sac, ML - medial lamellae, PD - proximal diverticula of internal sac. 
Spermatheca as in Fig. 203.

Distribution. Known from the Plott Balsams - Cataloochee Divide massif (North Carolina) (Figs. 338, 340).

Natural History. Geostiba balsamensis was collected at altitudes of 1300-1900 m in leaf litter in pure conifer or mixed forest with red spruce (Picea rubens), Fraser's fir (Abies fraseri) or hemlock.

\section{Geostiba (Sibiota) nubigena Lohse \& Smetana, 1988 (Figs. 213-246)}

Geostiba nubigena Lohse \& Smetana, 1988: 273.

Geostiba nubigena: Pace, 1997: 104.

Type material. Holotype, $\sigma^{x}$, UNITED STATES: North Carolina: Haywood Co.:

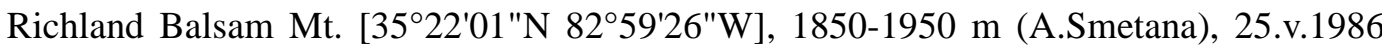

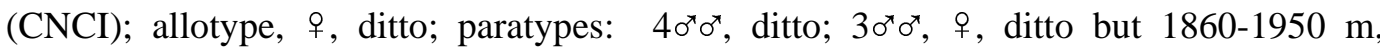

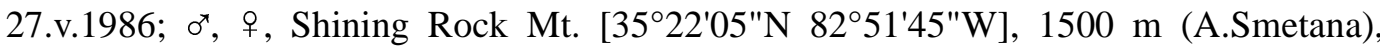
31.v.1986 (all - CNCI).

Additional material. UNITED STATES: North Carolina: Haywood Co.: $\sigma^{x}$, same data as the holotype (CNCI); 14 specimens, Black Balsam Knob Road N of Blue Ridge Parkway, $21 \mathrm{~km}$ SSE Waynesville, 35²19.1'N 82 $52.6^{\prime} \mathrm{W}, 1800 \mathrm{~m}$, in forest litter, Picea (V.I.Gusarov), 20.ix.2001; 12 specimens, Blue Ridge Parkway above Graveyard Fields parking, right bank of the river, $22 \mathrm{~km} \mathrm{SE}$ Waynesville, $35^{\circ} 19.1^{\prime} \mathrm{N} 82^{\circ} 50.7^{\prime} \mathrm{W}, 1600 \mathrm{~m}$, in forest litter, Picea, Betula (V.I.Gusarov), 20.ix.2001; 18 specimens, Blue Ridge Parkway at Graveyard Fields, right bank of the river, $22 \mathrm{~km}$ SE Waynesville, $35^{\circ} 19.2^{\prime} \mathrm{N} 82^{\circ} 50.7^{\prime} \mathrm{W}$, $1550 \mathrm{~m}$, in forest litter by the river, Picea, Betula, Rhododendron, Vaccinium (V.I.Gusarov), 20.ix.2001; 15 specimens, Graveyard Fields, left bank of the river, $22 \mathrm{~km} \mathrm{SE}$ Waynesville, $35^{\circ} 19.57^{\prime} \mathrm{N} 82^{\circ} 51.01 ' \mathrm{~W}, 1570 \mathrm{~m}$, in forest litter, Picea (V.I.Gusarov), 20.ix.2001; 2 specimens, Graveyard Fields, right bank of the river, $23 \mathrm{~km}$ SE Waynesville, $35^{\circ} 19.24^{\prime} \mathrm{N} 82^{\circ} 50.87^{\prime} \mathrm{W}, 1600 \mathrm{~m}$, in forest litter, Rhododendron (V.I.Gusarov), 24.vi.2001; 2 specimens, environs of Sam Knob, $21 \mathrm{~km}$ SE Waynesville, $35^{\circ} 19.62^{\prime} \mathrm{N} 82^{\circ} 53.08^{\prime} \mathrm{W}$, 1800 m, mountain meadows, in dead grass (V.I.Gusarov), 24.vi.2001; 6 specimens, Highway $215,21 \mathrm{~km} \mathrm{SSE}$ Waynesville, $35^{\circ} 18.80^{\prime} \mathrm{N} 82^{\circ} 54.78^{\prime} \mathrm{W}, 1500 \mathrm{~m}$, in forest litter, Picea, Betula, Rhododendron (V.I.Gusarov), 24.vi.2001; Haywood Co. / Jackson Co.: ơ, Blue Ridge Parkway, Grassy Ridge Mine Overlook, 8 km SSW Waynesville, 35 $24.94^{\prime} \mathrm{N}$ $83^{\circ} 02.80^{\prime} \mathrm{W}, 1650 \mathrm{~m}$, in forest litter, Tsuga, Quercus, Betula (V.I.Gusarov), 2.vi.2001; 14 specimens, Blue Ridge Parkway, 21 km SSE Waynesville, $35^{\circ} 18.42^{\prime} \mathrm{N} 82^{\circ} 56.47 \mathrm{~W}, 1600$ m, in forest litter, Picea rubens, Abies fraseri, Oxalis (V.I.Gusarov), 3.vi.2001; 9 specimens, ditto but $13 \mathrm{~km} \mathrm{~S}$ Waynesville, $35^{\circ} 22.12^{\prime} \mathrm{N} 82^{\circ} 59.65^{\prime} \mathrm{W}, 1800 \mathrm{~m} ; 12$ specimens, ditto but $11 \mathrm{~km} \mathrm{SSW}$ Waynesville, $35^{\circ} 23.3^{\prime} \mathrm{N} 83^{\circ} 02^{\prime} \mathrm{W}, 1800 \mathrm{~m}$, in forest litter, Picea rubens, Abies fraseri, Betula, Oxalis, 2.vi.2001; 3 specimens, Richland Balsam Mt., near 
summit, $14 \mathrm{~km} \mathrm{~S}$ Waynesville, $35^{\circ} 22.50^{\prime} \mathrm{N} 82^{\circ} 59.43^{\prime} \mathrm{W}, 1950 \mathrm{~m}$, in forest litter, Picea rubens, Abies fraseri, Vaccinium (V.I.Gusarov), 3.vi.2001; 2 specimens, ditto but W slope of Richland Balsam Mt., 35 $22.28^{\prime} \mathrm{N} 82^{\circ} 59.42^{\prime} \mathrm{W}, 1900 \mathrm{~m}$, in forest litter, Picea rubens, Abies fraseri; 2 specimens, ditto but $\mathrm{S}$ slope of Richland Balsam Mt., 35 $21.04^{\prime} \mathrm{N}$ $82^{\circ} 59.56^{\prime} \mathrm{W}, 1850 \mathrm{~m}$, in forest litter, Picea rubens, Abies fraseri, Betula, Oxalis; Haywood Co. / Transylvania Co.: 3 specimens, Blue Ridge Parkway, $23 \mathrm{~km}$ SE Waynesville, $35^{\circ} 19.13^{\prime} \mathrm{N} 82^{\circ} 50.08^{\prime} \mathrm{W}, 1500 \mathrm{~m}$, in forest litter, Quercus, Picea rubens, Tsuga, Fagus, Acer, Rhododendron, Vaccinium (V.I.Gusarov), 3.vi.2001; o $^{\star}$, Blue Ridge Parkway, $22 \mathrm{~km}$ SSE Waynesville, $35^{\circ} 18.32^{\prime} \mathrm{N} 82^{\circ} 53.49^{\prime} \mathrm{W}, 1700 \mathrm{~m}$, in forest litter, Picea, Abies, Quercus, Betula, Acer (V.I.Gusarov), 24.vi.2001; 24 specimens, Blue Ridge Parkway, 23 km SEE Waynesville, $35^{\circ} 25.2^{\prime} \mathrm{N} 82^{\circ} 45.0^{\prime} \mathrm{W}, 1550 \mathrm{~m}$, in forest litter, Picea, Rhododendron, Quercus (V.I.Gusarov), 20.ix.2001; Haywood Co. / Buncombe Co.: 6 specimens, Little Pisgah Mountain near summit, $22 \mathrm{~km}$ SEE Waynesville, $35^{\circ} 25.48^{\prime} \mathrm{N} 82^{\circ} 45.51^{\prime} \mathrm{W}, 1730-1760 \mathrm{~m}$, in forest litter, Fagus, Quercus, Rhododendron (V.I.Gusarov), 20.ix.2001; 12 specimens, S slope of Little Pisgah Mountain, $22 \mathrm{~km}$ SEE Waynesville, 35²5.05' $\mathrm{N} 82^{\circ} 45.81^{\prime} \mathrm{W}, 1650$ m, in forest litter, Picea, Betula, Acer (V.I.Gusarov), 20.ix.2001; Macon Co. / Clay Co.: $\sigma^{*}$, Blue Ridge, Appalachian National Scenic Trail, $21.5 \mathrm{~km}$ SW Franklin, 35 01.64'N 83³2.16'W, $1620 \mathrm{~m}$, in forest litter, Quercus, Kalmia latifolia (V.I.Gusarov), 23.vi.2001 (all - KSEM and SPSU).

Diagnosis. Geostiba nubigena can be distinguished from other Nearctic species of Geostiba by having small eyes (temple length to eye length ratio 4.3-6.0), pronotal pubescence of type $\mathrm{V}$, reduced wings, short elytra (pronotum length to elytron length ratio 1.3), the absence of carinae on abdominal tergum 7, the shape of the aedeagus (Figs. 219-234, 237-246) and the shape of the spermatheca (Figs. 235-236).

Geostiba nubigena differs from G. balsamensis in lacking the carinae on male tergum 7 and in having more narrow apex of median lobe (Figs. 219-220, 223-229, 193-194); from G. coeligena in having more narrow median lobe of aedeagus (in ventral view) (Figs. 219-220, 223-229, 249-250), long distal diverticula (Figs. 233-234, 253, 256) and small proximal diverticula of internal sac (Figs. 234, 253, 257-258).

Description. Length 1.8-2.2 mm. Uniformly brownish yellow, in some specimens abdominal segments 3-6 light brown. Body parallel-sided.

Head as wide as long, surface on disk with fine isodiametric microsculpture, puncturation very fine, distance between punctures equal to 2-4 times their diameter. Temple length to eye length ratio 4.3-6.0. Antennal article 2 longer than article 3, article 4-10 transverse to strongly transverse, last article as long as 9 and 10 combined.

Pronotum as wide as long, width $0.34-0.39 \mathrm{~mm}$, wider than head (pronotal width to head width ratio 1.1); microsculpture and puncturation as on head. Elytra measured from humeral angle shorter than pronotum (pronotal length to elytral length ratio 1.3), wider than long (1.4), with fine isodiametric microsculpture and fine asperate puncturation, distance between punctures equals 1-2 times their diameter. Pronotal pubescence of type V. 
Elytral suture behind scutellum slightly raised in both sexes. Wings reduced to short vestiges, shorter than elytra.

Abdominal terga with fine microsculpture of transverse meshes, with fine and sparse puncturation, puncturation becoming finer towards abdomen apex, on terga 3-5 distance between punctures equals 2-5 times their diameter. Tergum 7 without white edge.

Male tergum 7 without carinae. Posterior margin of male tergum 8 slightly convex (Fig. 213). Posterior margin of male sternum 8 convex (Fig. 214).

Female tergum 8 with slightly convex posterior margin (Fig. 215), sternum 8 with slightly emarginate posterior margin (Figs. 216-217).

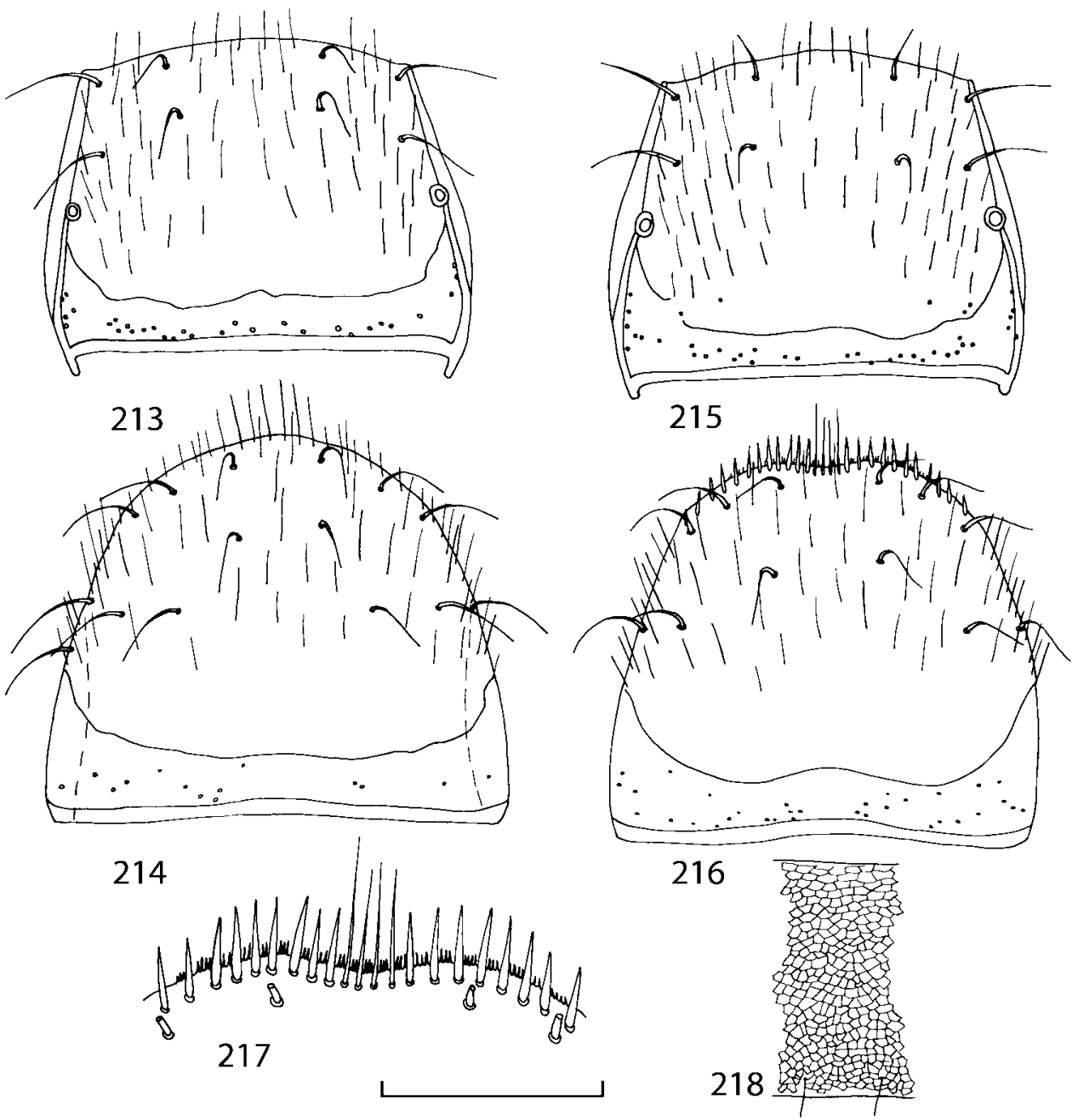

FIGURES 213-218. Abdominal segments 7-8 of Geostiba nubigena Lohse \& Smetana (Richland Balsam Mountain (213-215, 218) and Blue Ridge Parkway (216-217), North Carolina). 213 - male tergum $8 ; 214$ - male sternum $8 ; 215$ - female tergum $8 ; 216$ - female sternum 8,217 - apex of female sternum $8 ; 218$ - medial portion of female tergum 7 , posterior down. Scale bar $0.2 \mathrm{~mm}$ (213-216, 218), $0.1 \mathrm{~mm}(217)$. 

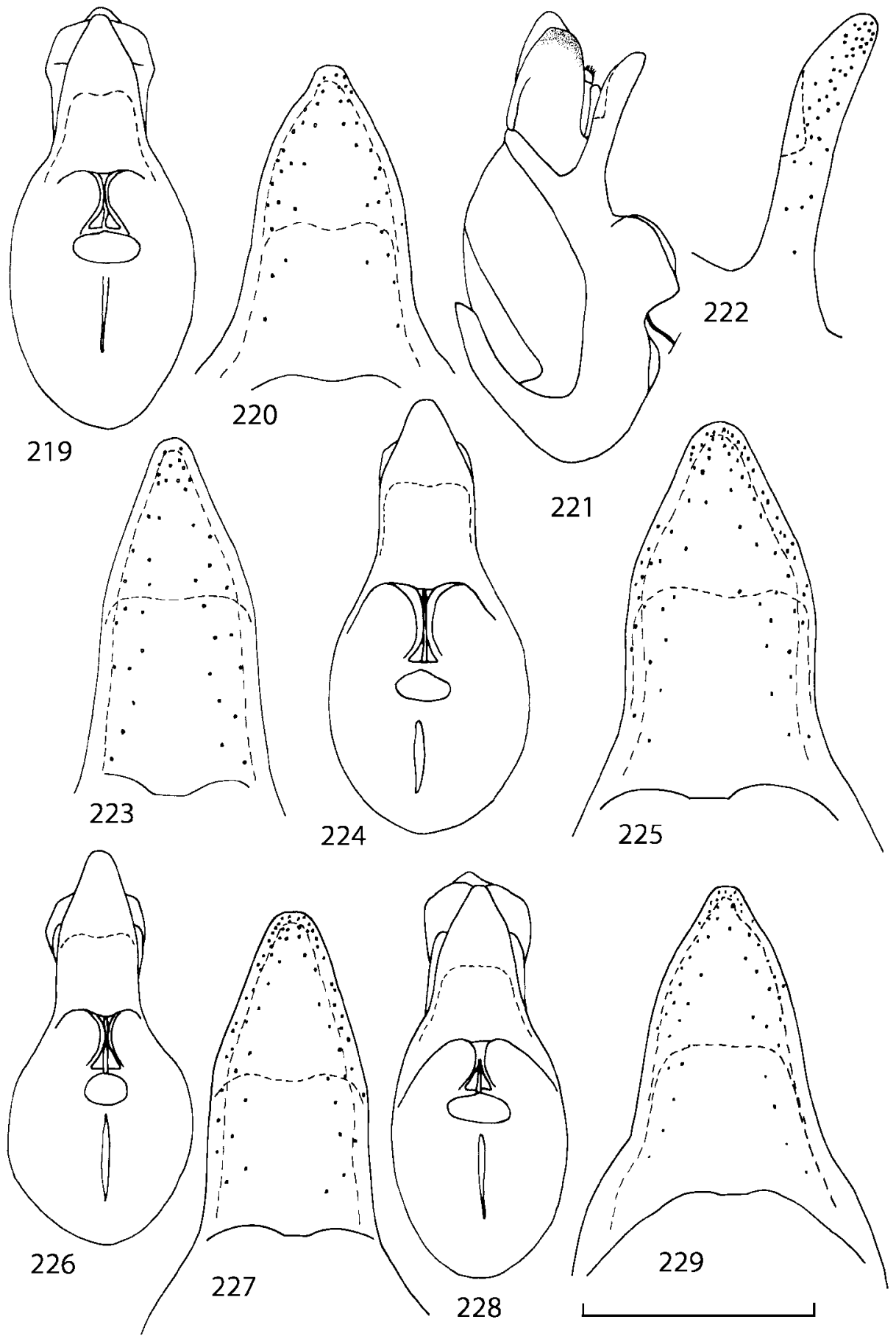

FIGURES 219-229. Aedeagus of Geostiba nubigena Lohse \& Smetana (Richland Balsam Mountain (219-222), Blue Ridge Parkway (223), Graveyard Fields (224-227) and Grassy Ridge Mine Overlook (228-229), North Carolina). 219, 224, 226, 228 - median lobe, ventral view; 220, 223, 225, 227, 229 - apex of median lobe, ventral view; 221 - median lobe, lateral view; 222 - apex of median lobe, lateral view. Scale bar $0.2 \mathrm{~mm}(219,221,224,226,228), 0.1 \mathrm{~mm}(220,222-223,225$, 227, 229). 


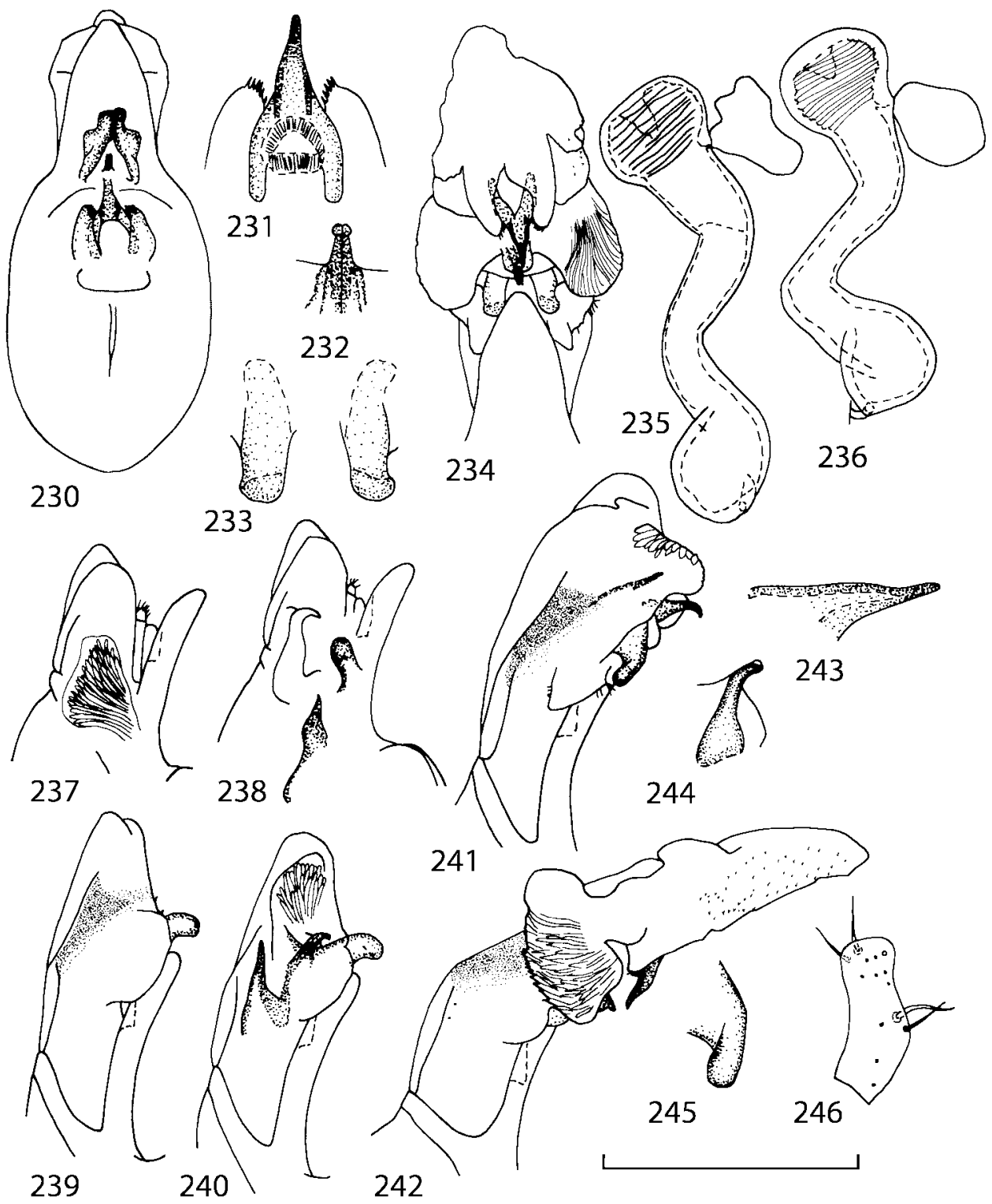

FIGURES 230-246. Genitalia of Geostiba nubigena Lohse \& Smetana (Richland Balsam Mountain (230-231, 234-235, 237-238, 242, 246) and Blue Ridge Parkway (232-233, 236, 239-241, 243245), North Carolina). 230 - details of internal sac retracted into median lobe, ventral view; 231 copulatory piece of internal sac, dorsal view; 232 - medial lamellae of internal sac, ventral view; 233 - distal diverticula of everted internal sac, ventral view; 234 - everted internal sac, ventral view; 235-236 - spermatheca; 237-238 - details of internal sac retracted into median lobe, lateral view; 239 - partially everted internal sac, lateral view; 240 - details of internal sac inside partially everted internal sac, lateral view; 241 - everted internal sac, lateral view; 242 - completely everted internal sac, lateral view; 243 - copulatory piece of internal sac, lateral view; 244 - medial lamella of internal sac, lateral view; 245 - right distal diverticulum of everted internal sac, lateral view; 246 - apex of left paramere, side facing median lobe. Scale bar $0.2 \mathrm{~mm}(230,234,237-242), 0.1 \mathrm{~mm}$ (231-233, 235-236, 243-246). 
Aedeagus as in Figs. 219-234, 237-246. Apex of median lobe in lateral view strait (Figs. 221-222).

Spermatheca as in Figs. 235-236.

Distribution and variability. Known from the Great Balsam Mountains - Pisgah Ridge massif and from Standing Indian in the Blue Ridge (North Carolina) (Figs. 338, 340). Geostiba nubigena is variable in the shape of aedeagus median lobe (Figs. 219-229). Forms from different mountains have different shape of median lobe, but when specimens from many localities were compared no cline or clear hiatus between different forms were found. The locality on Standing Indian is quite distant from other localities in the Great Balsam Mts.-Pisgah Ridge massif. However in aedeagus shape the specimens from Standing Indian fall within the range of variability of G. nubigena.

Natural History. Geostiba nubigena was collected at altitudes above $1500 \mathrm{~m}$ in leaf litter, mostly in forests with red spruce (Picea rubens) and Fraser's fir (Abies fraseri), in some localities in forests with oak, beech, rhododendron and mountain laurel but without any conifers.

\section{Geostiba (Sibiota) coeligena Gusarov, sp. n. (Figs. 247-261)}

Type material. Holotype, ơ UNITED STATES: Tennessee / North Carolina: Sevier Co. / Swain Co.: Appalachian National Scenic Trail, W of Clingmans Dome, $16 \mathrm{~km} \mathrm{~S}$ Gatlinburg, $35^{\circ} 33.88^{\prime} \mathrm{N} 83^{\circ} 31.41^{\prime} \mathrm{W}, 1930 \mathrm{~m}$, in forest litter, Picea, Abies, Betula, Oxalis (V.I.Gusarov), 22.vi.2001 (KSEM).

Paratype: $0^{x}$, as the holotype but $35^{\circ} 33.74^{\prime} \mathrm{N} 83^{\circ} 30.84^{\prime} \mathrm{W}, 1950 \mathrm{~m}$, in forest litter, Abies, Vaccinium, Oxalis (SPSU).

Diagnosis. Geostiba coeligena can be distinguished from other Nearctic species of Geostiba by having small eyes (temple length to eye length ratio 4.0-5.6), pronotal pubescence of type $\mathrm{V}$, reduced wings, short elytra (pronotum length to elytron length ratio 1.4), the absence of carinae on abdominal tergum 7 and the shape of the aedeagus (Figs. 249261).

Geostiba coeligena differs from G. balsamensis in lacking the carinae on male tergum 7; from G. nubigena in having broader median lobe of aedeagus (in ventral view) (Figs. 249-250, 219-220, 223-229), short distal diverticula (Figs. 253, 256, 233-234) and large proximal diverticula of internal sac (Figs. 253, 257-258, 234).

Description. Length 1.8-1.9 mm. Body brownish yellow to brown, antennae light brown, mouthparts and legs brownish yellow. Body parallel-sided.

Head as wide as long, surface on disk with fine isodiametric microsculpture, puncturation very fine, distance between punctures equal to 3-4 times their diameter. Temple length to eye length ratio 4.0-5.6. Antennal article 2 longer than article 3, article 4-10 transverse to strongly transverse, last article as long as 9 and 10 combined. 
Pronotum as wide as long, width $0.34 \mathrm{~mm}$, wider than head (pronotal width to head width ratio 1.1); microsculpture and puncturation as on head. Pronotal pubescence of type V. Elytra measured from humeral angle shorter than pronotum (pronotal length to elytral length ratio 1.4), wider than long (1.5), with fine isodiametric microsculpture and fine asperate puncturation, distance between punctures equals 2-3 times their diameter. Elytral suture behind scutellum very slightly raised. Wings reduced to short vestiges, shorter than elytra.

Abdominal terga with fine microsculpture of transverse meshes, with fine and sparse puncturation, puncturation becoming finer towards abdomen apex, on terga 3-5 distance between punctures equals 3-6 times their diameter. Tergum 7 without white edge.

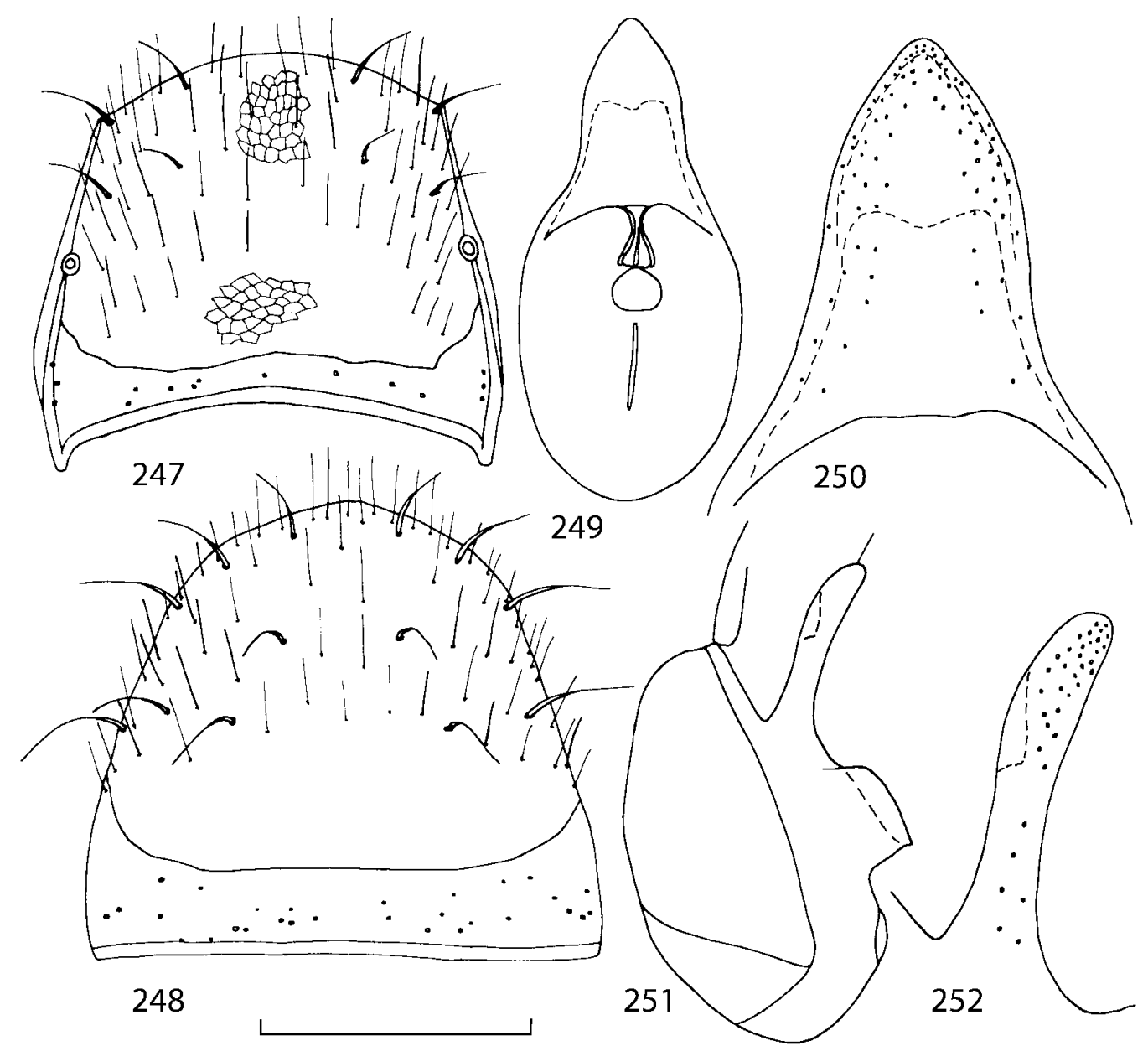

FIGURES 247-252. Abdominal segment 8 and aedeagus of Geostiba coeligena Gusarov, sp. $\mathbf{n}$. (paratype). 247 - male tergum 8; 248 - male sternum 8; 249 - median lobe, ventral view; 250 apex of median lobe, ventral view; 251 - median lobe, lateral view; 252 - apex of median lobe, lateral view. Scale bar $0.2 \mathrm{~mm}(247-249,251), 0.1 \mathrm{~mm}(250,252)$. 
Male tergum 7 without carinae. Posterior margin of male tergum 8 and sternum 8 convex (Figs. 247-248).

Aedeagus as in Figs. 249-261. Apex of median lobe in lateral view strait (Figs. 251252).

Female unknown.

Distribution. Known from the Great Smoky Mountains massif west of Clingmans Dome (Figs. 338, 340).

Natural History. Geostiba coeligena was collected in forest litter at altitudes above $1900 \mathrm{~m}$ in leaf litter mostly in coniferous forest with Fraser's fir (Abies fraseri) and red spruce (Picea rubens).

Etymology. The specific name is derived from the Latin noun coelum (the sky, the heavens) and the verb gigno (to be born, to arise). It refers to the high mountains where the species occurs.
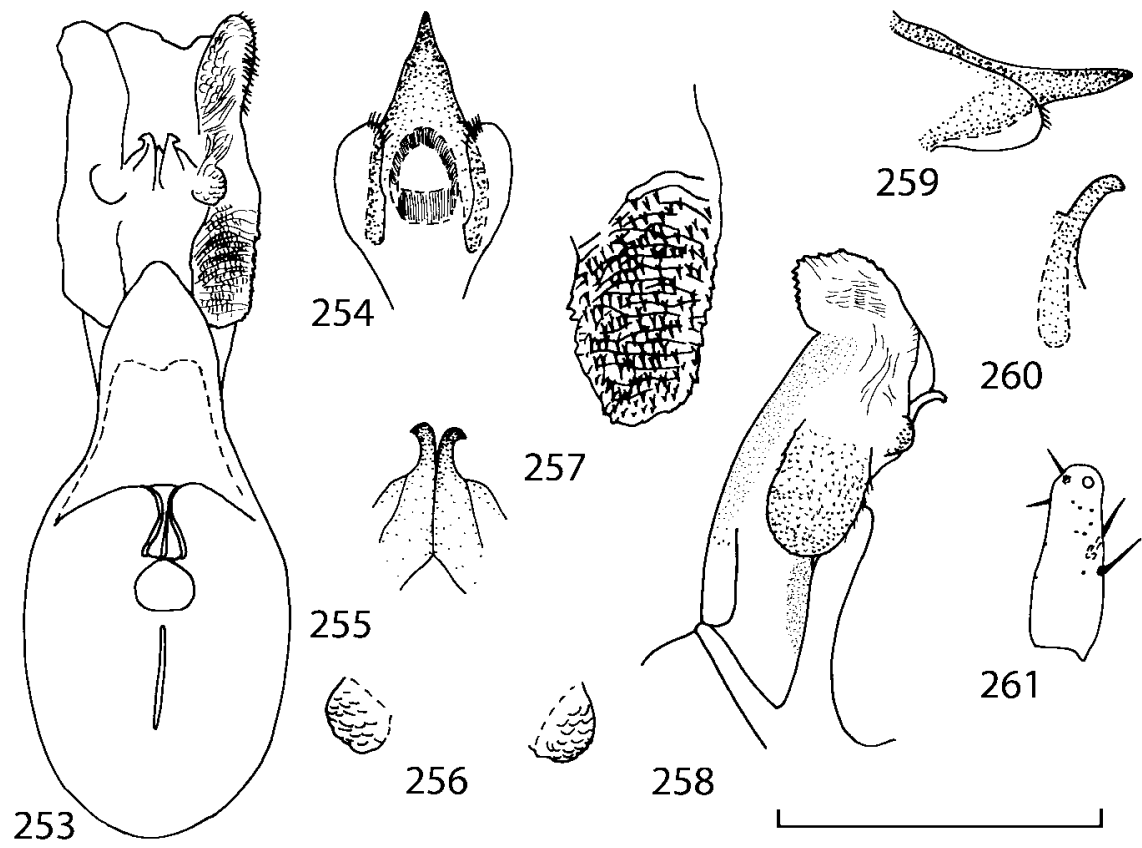

256

258

FIGURES 253-261. Aedeagus of Geostiba coeligena Gusarov, sp. n. (253, 256-258, 260-261 paratype, 254-255, 259 - holotype). 253 - everted internal sac, ventral view; 254 - copulatory piece of internal sac, dorsal view; 255 - medial lamellae of internal sac, ventral view; 256 - distal diverticula of everted internal sac, ventral view; 257 - left proximal diverticulum of everted internal sac, ventral view; 258 - everted internal sac, lateral view; 259 - copulatory piece of internal sac, lateral view; 260 - medial lamella of internal sac, lateral view; 261 - apex of left paramere, side facing median lobe. Scale bar $0.2 \mathrm{~mm}(253,258), 0.1 \mathrm{~mm}(254-257,259-261)$. 
Geostiba alticola Lohse \& Smetana, 1988: 271.

Geostiba bicarinata: Lohse \& Smetana, 1988: 273, ex parte (misidentification).

Geostiba (Lioglutosipalia) carteriensis: Pace, 1997: 106, ex parte (misidentification).

Type material. Holotype, ơ , UNITED STATES: North Carolina: Buncombe Co.: Blue Ridge Parkway, Grey Beard Mountain View [3542'37"N 82²1'51"W], $1700 \mathrm{~m}$ (A.Smetana), 4.vi.1986 (CNCI); allotype, ㅇ, North Carolina: Yancey Co.: Mt. Mitchell, 2000-2036m (A.Smetana), 4.vi.1986; paratypes: $30^{x} 0^{x}, 3$ 우우, the same data as the holotype; $40^{x} 0^{x}$, 우, the same data as the allotype (all-CNCI).
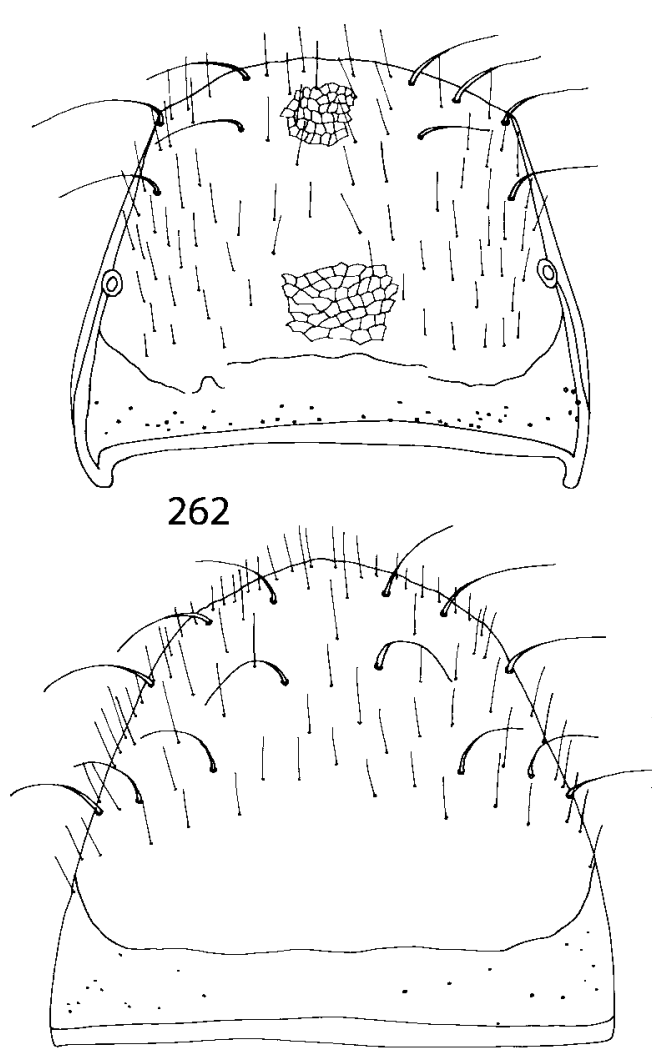

263

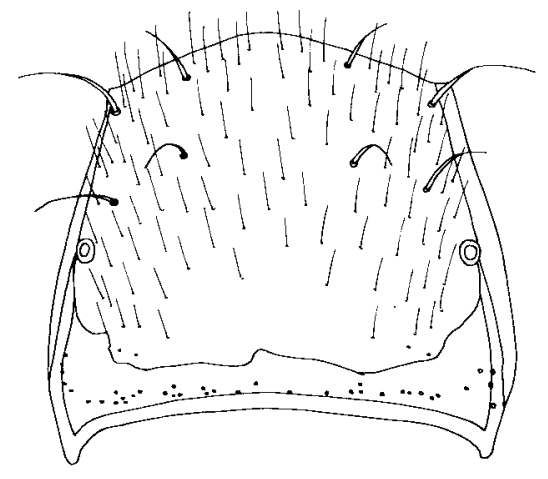

264

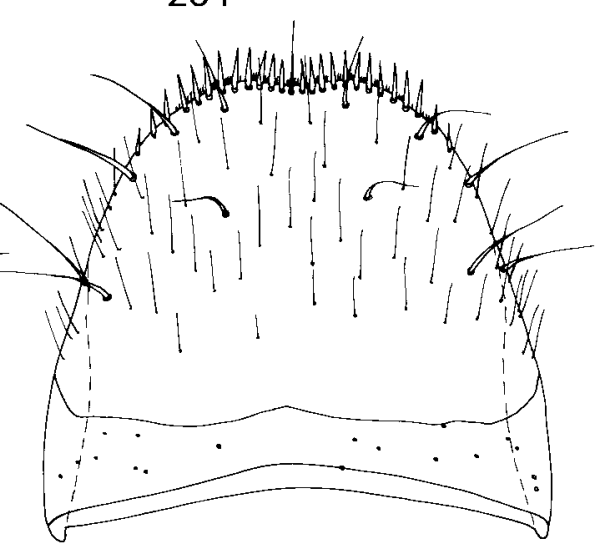

265

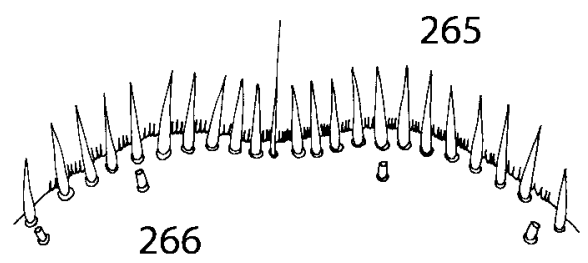

FIGURES 262-266. Abdominal segment 8 of Geostiba alticola Lohse \& Smetana (N slope of Mt. Mitchell (262-263) and $21 \mathrm{~km} \mathrm{~S}$ Burnsville (264-266), North Carolina). 262 - male tergum 8; 263 - male sternum $8 ; 264$ - female tergum $8 ; 265$ - female sternum 8,266 - apex of female sternum 8. Scale bar $0.2 \mathrm{~mm}$ (262-265), $0.1 \mathrm{~mm}$ (266). 


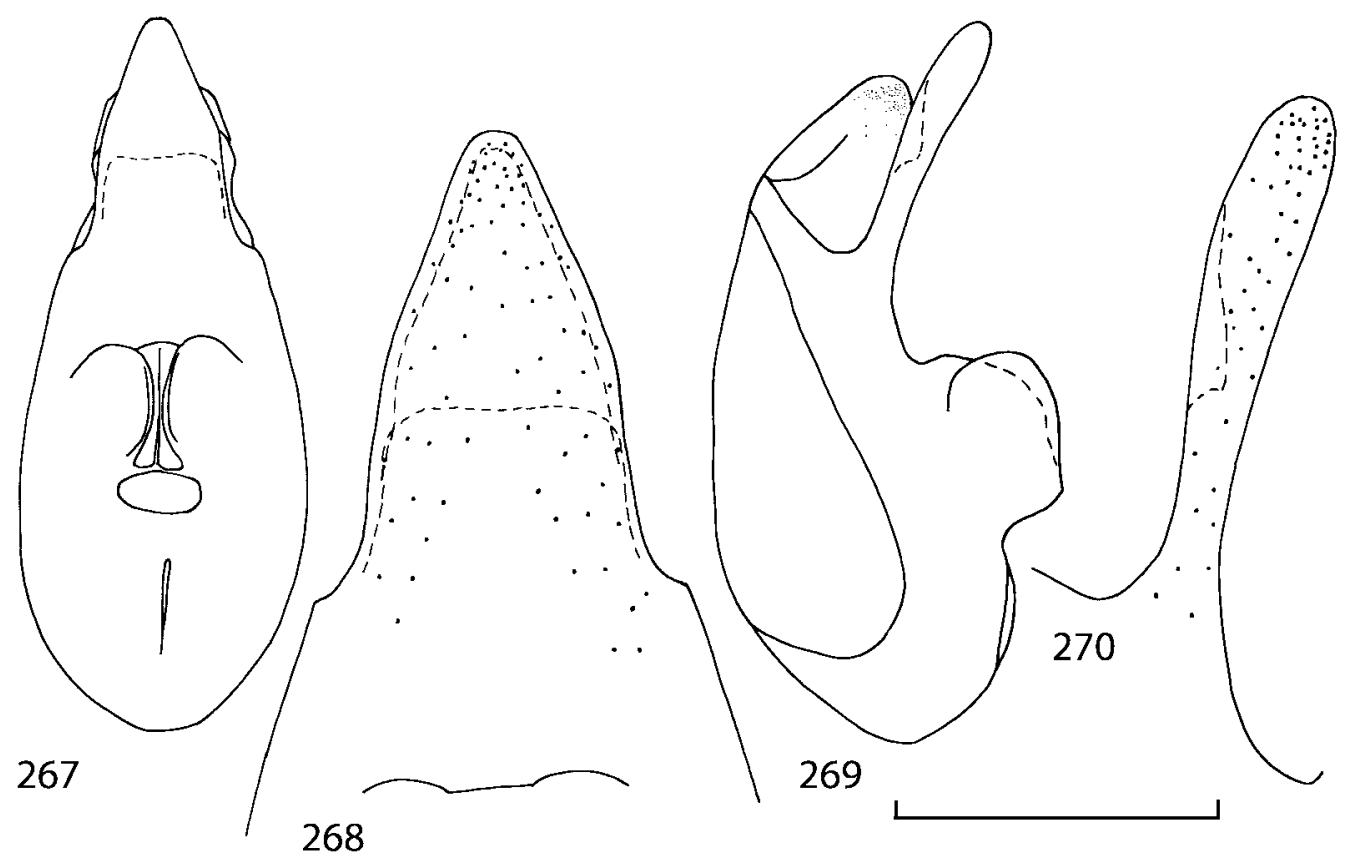

FIGURES 267-270. Aedeagus of Geostiba alticola Lohse \& Smetana (N slope of Mt. Mitchell, North Carolina). 267 - median lobe, ventral view; 268 - apex of median lobe, ventral view; 269 median lobe, lateral view; 270 - apex of median lobe, lateral view. Scale bar $0.2 \mathrm{~mm}(267,269)$, $0.1 \mathrm{~mm}(268,270)$.

Additional material. UNITED STATES: North Carolina: McDowell Co.[?]: 27 specimens, Mt. Mitchell, Blue Ridge Parkway, $1700 \mathrm{~m}$ [this label is not precise; Mt. Mitchell is in Yancey County at least 5 kilometers from Blue Ridge Parkway; it is not possible to find coordinates for this sample] (J.S. \& A.K.Ashe), sifted conifer litter,

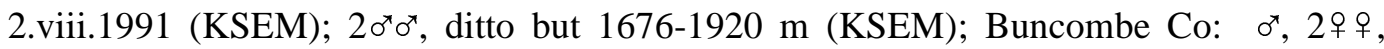
Craggy Dome, [35०42'20"N 82²2'00"W] (T.C.Barr, M.C.Bowling), 22.vii.1960 (AMNH); ㅇ, Blue Ridge Parkway, 16 km E Weaverville, Bearpen Knob, 35 41.91' N $82^{\circ} 23.05^{\prime} \mathrm{W}, 1740 \mathrm{~m}$, mountain meadows, in dead grass under Rhododendron and Sorbus (V.I.Gusarov), 25.vi.2001 (SPSU); 12 specimens, ditto but 3541.91' $-42.02^{\prime} \mathrm{N} 82^{\circ} 23.05$ $22.83^{\prime} \mathrm{W}, 1700 \mathrm{~m}$, in forest litter, Acer, Betula, Rhododendron; 18 specimens, $15 \mathrm{~km} \mathrm{E}$

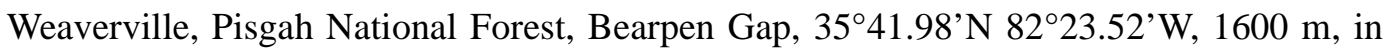
forest litter, Picea, Fagus, Betula (V.I.Gusarov), 25.vi.2001; 8 specimens, Blue Ridge Parkway, $18 \mathrm{~km}$ E Weaverville, 35² $42.78^{\prime} \mathrm{N} 82^{\circ} 21.89^{\prime} \mathrm{W}, 1720 \mathrm{~m}$, in forest litter, Picea, Betula (V.I.Gusarov), 25.vi.2001 (all - KSEM and SPSU); Yancey Co.: 우, Black Moun-

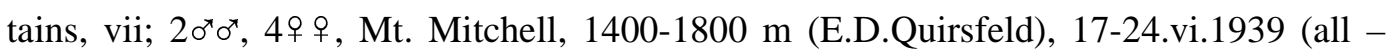
AMNH); 141 specimens, Mt.Mitchell (W.Suter), 12.vi.1973; 73 specimens, Mt.Mitchell near Blue Ridge Parkway, 1500 m (W.Suter), 17.vi.1973; 118 specimens, Mt.Mitchell, 1700 m (S.Peck), 9.iv.1967; ơ, Mt.Mitchell, balsam fir litter above spring near summit (W.Suter), 31.v1973 (all - FMNH); 20 specimens, 16 km S Burnsville, Mt.Mitchell State 

(V.I.Gusarov), 25.vi.2001; 15 specimens, $21 \mathrm{~km} \mathrm{~S}$ Burnsville, Road 128, 3543.42’ N $82^{\circ} 16.97^{\prime} \mathrm{W}, 1600 \mathrm{~m}$, in forest litter, Picea, Abies, Betula, Acer (V.I.Gusarov), 25.vi.2001, $\circ^{\star}$, ditto but $35^{\circ} 43.32^{\prime} \mathrm{N} 82^{\circ} 17.29^{\prime} \mathrm{W}$, 3.vi.2001; 15 specimens, Road 128, 19 km S Burns-

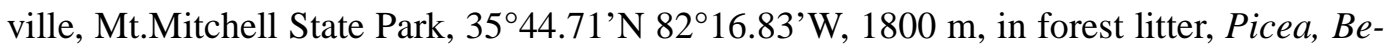
tula (V.I.Gusarov), 25.vi.2001; 6 specimens, Road 128, 17 km S Burnsville, Mt.Mitchell, $35^{\circ} 45.92^{\prime} \mathrm{N} 82^{\circ} 16.26^{\prime} \mathrm{W}, 1920 \mathrm{~m}$, in forest litter, Abies (V.I.Gusarov), 25.vi.2001; ơ 17 $\mathrm{km}$ S Burnsville, Mt.Mitchell, near summit, 35 $45.58^{\prime} \mathrm{N} 82^{\circ} 15.51^{\prime} \mathrm{W}, 2050 \mathrm{~m}$, in forest litter, Picea rubens, Abies fraseri (V.I.Gusarov), 3.vi.2001; Yancey Co. / Buncombe Co.: 19 specimens, 19 km S Burnsville, Blue Ridge Parkway, Balsam Gap overlook, 3544.86’ $\mathrm{N}$ $82^{\circ} 19.94^{\prime} \mathrm{W}, 1650 \mathrm{~m}$, in forest litter, Picea, Abies, Betula, Acer (V.I.Gusarov), 25.vi.2001 (all - KSEM and SPSU).

One of the paratypes of G. bicarinata listed by Lohse and Smetana (1988: 275) (not found in CNCI) must also belong to G. alticola (1 specimen, Buncombe Co.: base of Mt. Mitchell at Blue Ridge Parkway, about 1650 m (A.Smetana), 3.vi.1986). Two of the paratypes of G. carteriensis listed by Pace (1997: 106) (not examined) must also belong to G. alticola (20 $0^{x} 0^{x}$, Yancey Co.: Mt. Mitchell, $1800 \mathrm{~m}$ (P.Debs), 17.iv.1974). These assertions are based on the results of my extensive collecting efforts which demonstrated that G. bicarinata is restricted to the Great Balsam Mountains - Pisgah Ridge massif, G. carteriensis is restricted to the Bald Mountains and the Roan Mountain massif while G. alticola is the only species of Geostiba which occurs in the Great Craggy Mountains - Black Mountains massif.

Mislabeled material. ${ }^{x}$, United States: Alabama: Blount Co.: 1 mi. SE Blount Springs (S.Peck), 5.iv.1967 (FMNH). This male is identical with the types of G. alticola and other specimens from the Black Mountains massif in all external characters and in genitalia. Geostiba alticola is a wingless species restricted to the Great Craggy Mountains - Black Mountains massif in the Southern Appalachians and occurs only above $1500 \mathrm{~m}$. The altitude of the locality in Alabama is about $200 \mathrm{~m}$. I consider the Alabama specimen to have been mislabeled. It is worth noting that four days later, on April 9, 1967, Stewart Peck collected a long series of G. alticola on the Mount Mitchell. Apparently one specimen was misplaced and mixed up with a sample from Alabama. Geostiba alticola does not occur in Alabama.

Diagnosis. Geostiba alticola can be distinguished from other Nearctic species of Geostiba by having small eyes (temple length to eye length ratio 3.8-5.0), pronotal pubescence of type V or VI, directed posteriorly in a wide medial zone (wider in males), not just along the midline, reduced wings, short elytra (pronotum length to elytron length ratio 1.3), the absence of carinae on abdominal tergum 7, the shape of the aedeagus (Figs. 267-275, 277283) and the shape of the spermatheca (Fig. 276).

Geostiba alticola differs from closely related G. carteriensis in having longer and more narrow (in lateral view) apex of the median lobe of aedeagus (Figs. 269-270, $292-$ 

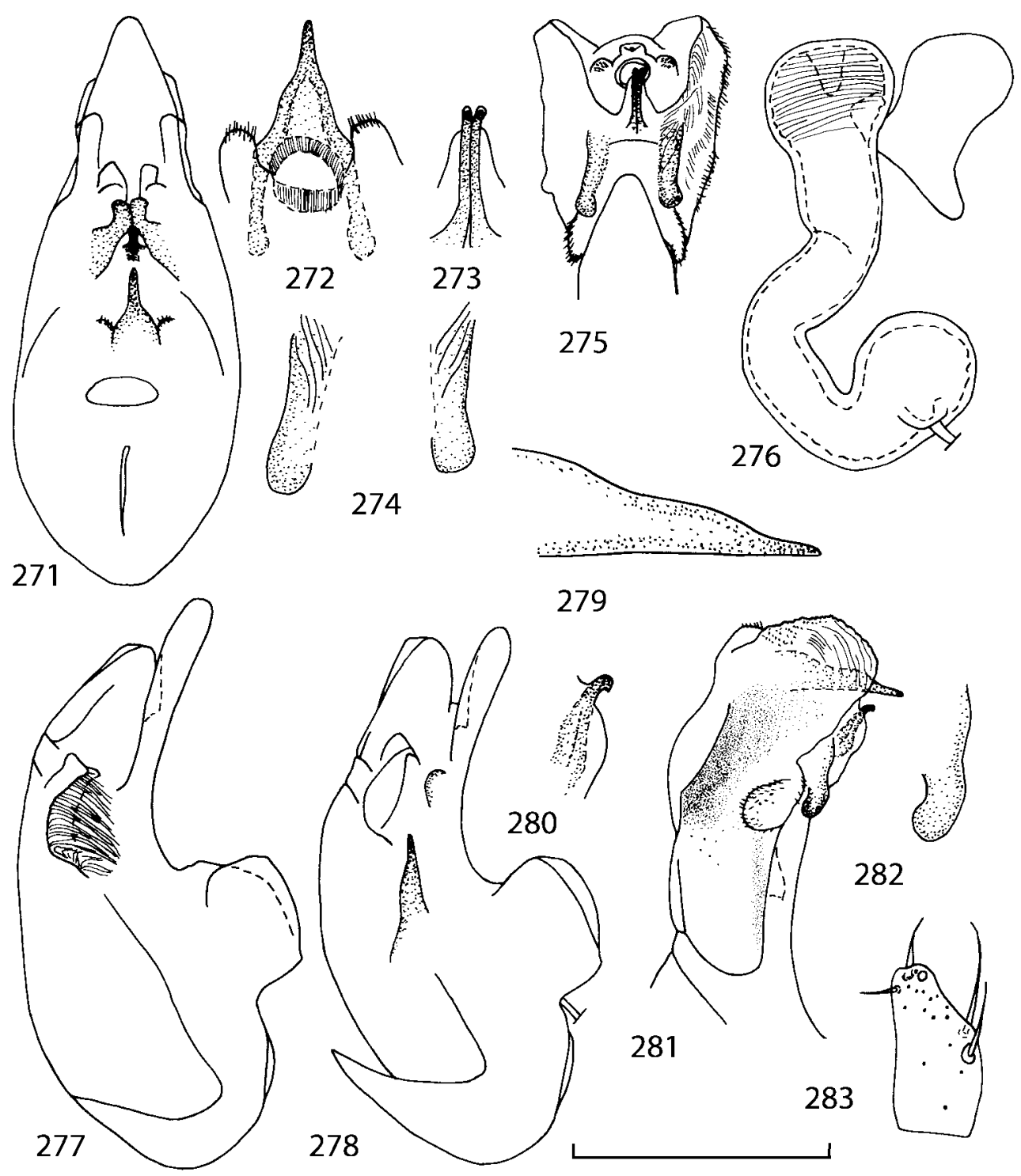

FIGURES 271-283. Genitalia of Geostiba alticola Lohse \& Smetana (Mt. Mitchell (272-275, 278282), N slope of Mt. Mitchell (271, 277, 283) and $21 \mathrm{~km} \mathrm{~S} \mathrm{Burnsville} \mathrm{(276),} \mathrm{North} \mathrm{Carolina).} 271$ - details of internal sac retracted into median lobe, ventral view; 272 - copulatory piece of internal sac, dorsal view; 273 - medial lamellae of internal sac, ventral view; 274 - distal diverticula of everted internal sac, ventral view; 275 - everted internal sac, ventral view; 276 - spermatheca; 277278 - details of internal sac retracted into median lobe, lateral view; 279 - copulatory piece of internal sac, lateral view; 280 - medial lamella of internal sac, lateral view; 281 - everted internal sac, lateral view; 282 - right distal diverticulum of everted internal sac, lateral view; 283 - apex of left paramere, side facing median lobe. Scale bar $0.2 \mathrm{~mm}(271,275,277-278,281), 0.1 \mathrm{~mm}(272-274$, 276, 279-280, 282-283). 
Description. Length 1.9-2.4 mm. Body uniformly light brown, in some specimens abdominal segments 3-6 darker. Body parallel-sided.

Head as wide as long, surface on disk with fine isodiametric microsculpture, puncturation very fine, distance between punctures equal to 2-4 times their diameter. Temple length to eye length ratio 3.8-5.0. Antennal article 2 longer than article 3, article 4 subquadrate, 5-10 transverse, last article as long as 9 and 10 combined.

Pronotum as wide as long, width $0.39-0.44 \mathrm{~mm}$, wider than head (pronotal width to head width ratio 1.1); microsculpture and puncturation as on head; pronotal pubescence of type V or VI (directed posteriorly in wide medial zone (wider in males), not just along midline). Elytra measured from humeral angle shorter than pronotum (pronotal length to elytral length ratio 1.3), wider than long (1.5), with fine isodiametric microsculpture and fine asperate puncturation, distance between punctures equals 2-3 times their diameter. Elytral suture behind scutellum very slightly raised. Wings reduced to short vestiges, shorter than elytra.

Abdominal terga with fine microsculpture of transverse meshes, with fine and sparse puncturation, puncturation becoming finer towards abdomen apex, on terga 3-5 distance between punctures equals 2-5 times their diameter. Tergum 7 without white edge.

Males with stronger impression on disc of head and along midline of pronotum than females. Male tergum 7 without carinae. Posterior margin of male tergum 8 slightly convex (Fig. 262). Posterior margin of male sternum 8 convex (Fig. 263).

Posterior margin of female tergum 8 convex (Fig. 264). Posterior margin of female sternum 8 concave medially (Figs. 265-266).

Aedeagus as in Figs. 267-275, 277-283. Apex of median lobe in lateral view strait (Figs. 269-270), in ventral view apex outline emarginate basally (Figs. 267-268). Distal diverticula of internal sac narrow (Figs. 274-275, 281-282).

Spermatheca as in Fig. 276.

Distribution. Known only from the Great Craggy Mountains - Black Mountains massif (Figs. 338-339).

Natural History. Geostiba alticola was collected in forest litter at altitudes above $1500 \mathrm{~m}$ in leaf litter mostly in pure conifer or mixed forest with red spruce (Picea rubens) and/or Fraser's fir (Abies fraseri).

\section{Geostiba (Sibiota) carteriensis Pace, 1997 (Figs. 284-305)}

Geostiba (Lioglutosipalia) carteriensis Pace, 1997: 106, ex parte.

Type material. Two paratypes of G. carteriensis belong to G. alticola: $20^{\star} 0^{x}$, Yancey Co.: Mt. Mitchell, 1800 m (P.Debs), 17.iv.1974 (not examined). My collecting demonstrated that these paratypes originate from the mountain massif where G. carteriensis does not occur. These presumably misidentified paratypes belong to G. alticola. 
Material. UNITED STATES: Tennessee / North Carolina: Carter Co. / Mitchell

Co.: 12 specimens, 29 km SSE Elizabethton, Roan Road Pass, Rd. 143/261, 36 06.3' N $82^{\circ} 06.8^{\prime} \mathrm{W}, 1700 \mathrm{~m}$, in forest litter and moss, Picea, Rhododendron (V.I.Gusarov), 17.iii.2001; Unicoi Co. / Yancey Co.: 12 specimens, 9 km E Lewisburg, Big Bald, $35^{\circ} 59.57^{\prime} \mathrm{N} 82^{\circ} 29.61^{\prime} \mathrm{W}, 1650 \mathrm{~m}$, meadows, in grass (V.I.Gusarov), 21.ix.2001 (all KSEM and SPSU).

Type locality. UNITED STATES: Tennessee / North Carolina: Carter Co. / Mitchell Co.: Roan Mountain, Forest Road 130, 6300’ (Pace 1997).

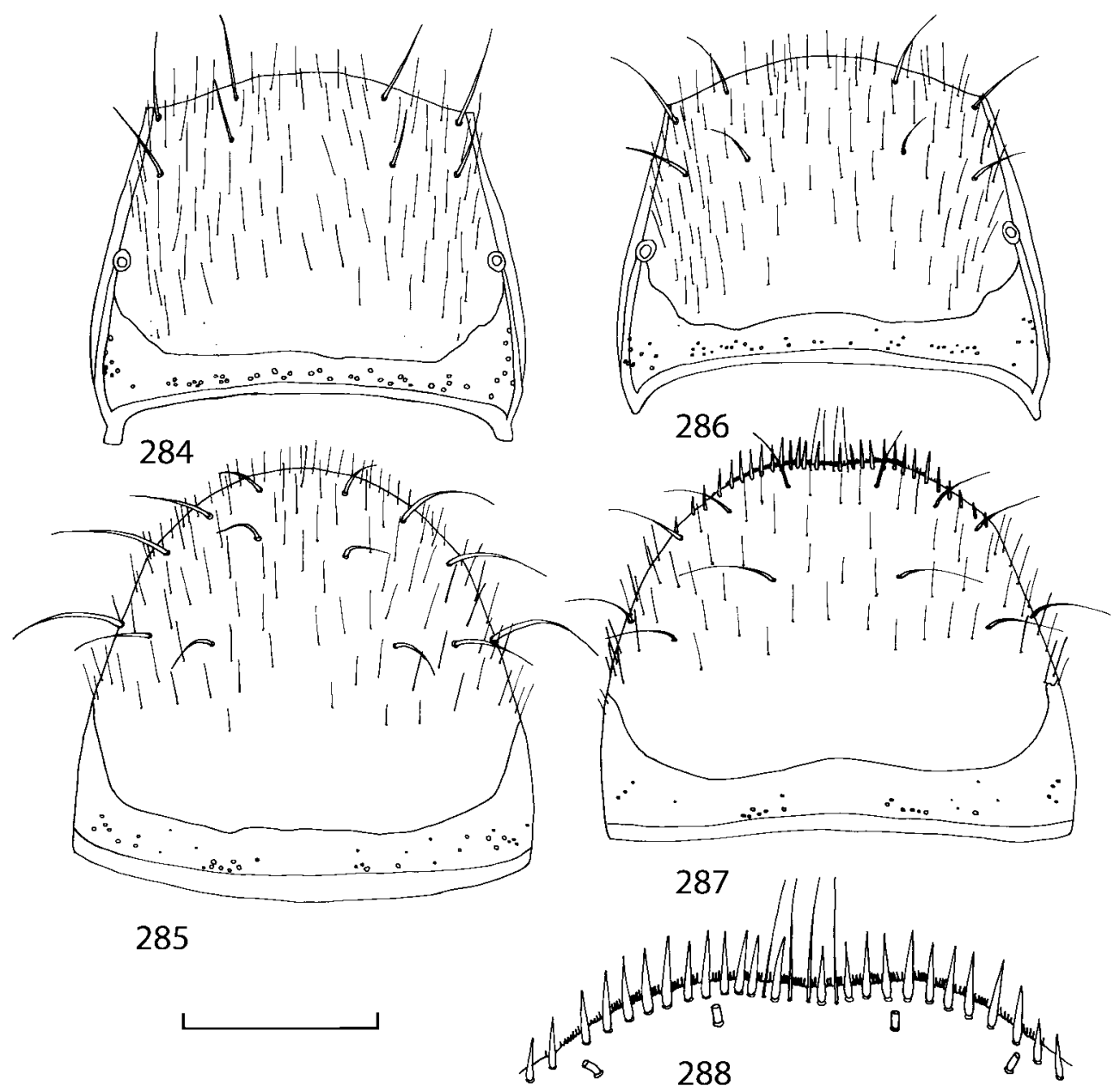

FIGURES 284-288. Abdominal segment 8 of Geostiba carteriensis Pace (Roan Road Pass, Tennessee / North Carolina). 284 - male tergum 8; 285 - male sternum 8; 286 - female tergum 8; 287 - female sternum 8, 288 - apex of female sternum 8. Scale bar $0.2 \mathrm{~mm}$ (284-287), $0.1 \mathrm{~mm}$ (288).

Diagnosis. Geostiba carteriensis can be distinguished from other Nearctic species of Geostiba by having small eyes (temple length to eye length ratio 3.8-4.6), pronotal pubes- 
cence of type V or VI, pronotal pubescence directed posteriorly in a wide medial zone (wider in males), not just along the midline, reduced wings, short elytra (pronotum length to elytron length ratio 1.3), the absence of carinae on abdominal tergum 7, the shape of the aedeagus (Figs. 289-298, 300-305) and the shape of the spermatheca (Fig. 299).

Geostiba carteriensis differs from closely related G. alticola in having shorter and wider (in lateral view) apex of the aedeagus median lobe (Figs. 292-293, 269-270) and the lateral sides of the apex more convex (in ventral view) (Figs. 289-291, 267-268).

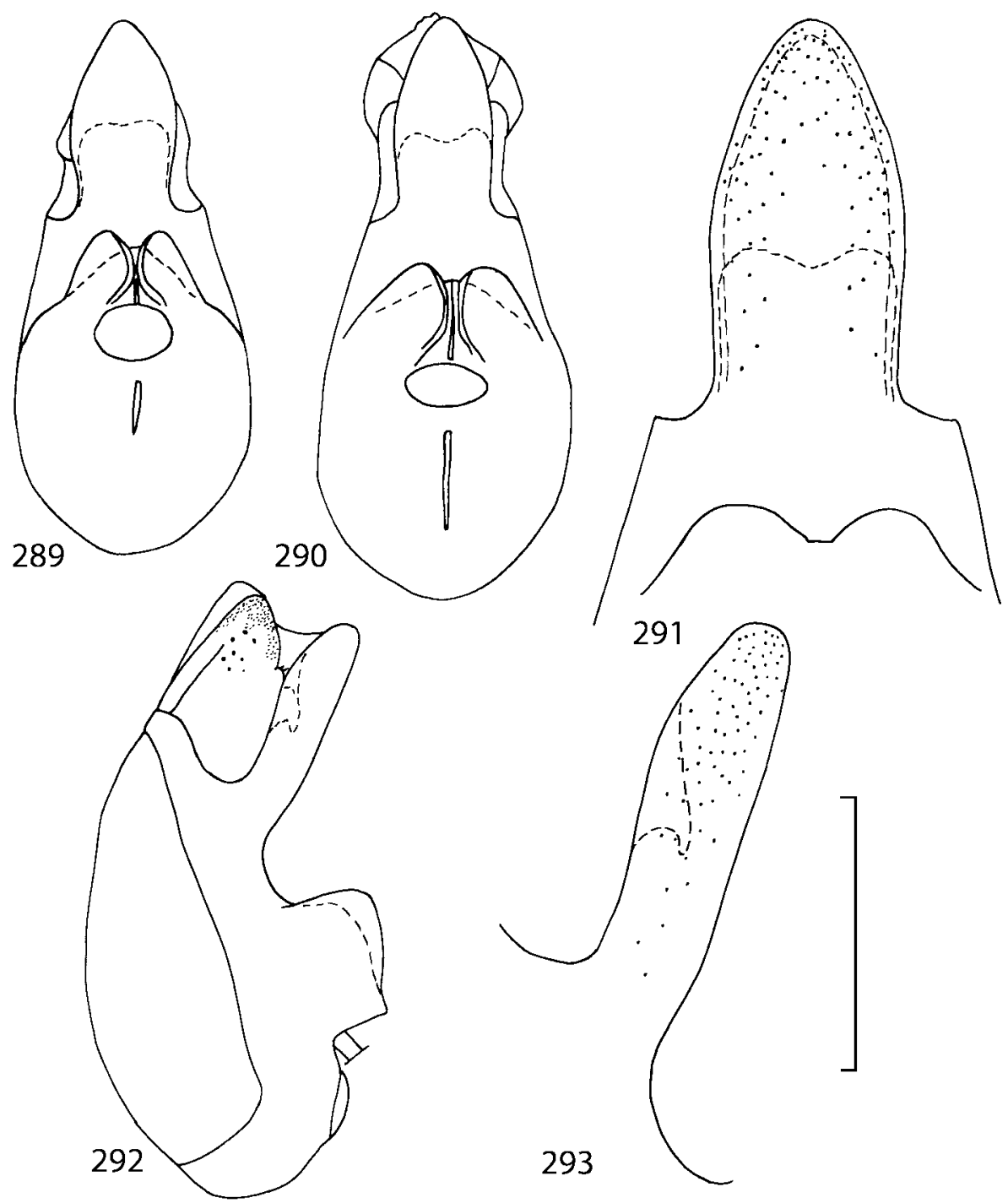

FIGURES 289-293. Aedeagus of Geostiba carteriensis Pace (Big Bald (289) and Roan Road Pass (290-293), Tennessee / North Carolina). 289-290 - median lobe, ventral view; 291 - apex of median lobe, ventral view; 292 - median lobe, lateral view; 293 - apex of median lobe, lateral view. Scale bar $0.2 \mathrm{~mm}$ (289-290, 292), $0.1 \mathrm{~mm}(291,293)$. 
Description. Length 2.2-2.6 mm. Body uniformly yellowish brown, in some specimens abdominal segments 3-6 darker. Body parallel-sided.

Head as wide as long, surface on disk with fine isodiametric microsculpture, puncturation very fine, distance between punctures equal to 2-4 times their diameter. Temple length to eye length ratio 3.8-4.6. Antennal article 2 longer than article 3, article 4 subquadrate, articles 5-10 transverse, last article as long as 9 and 10 combined.

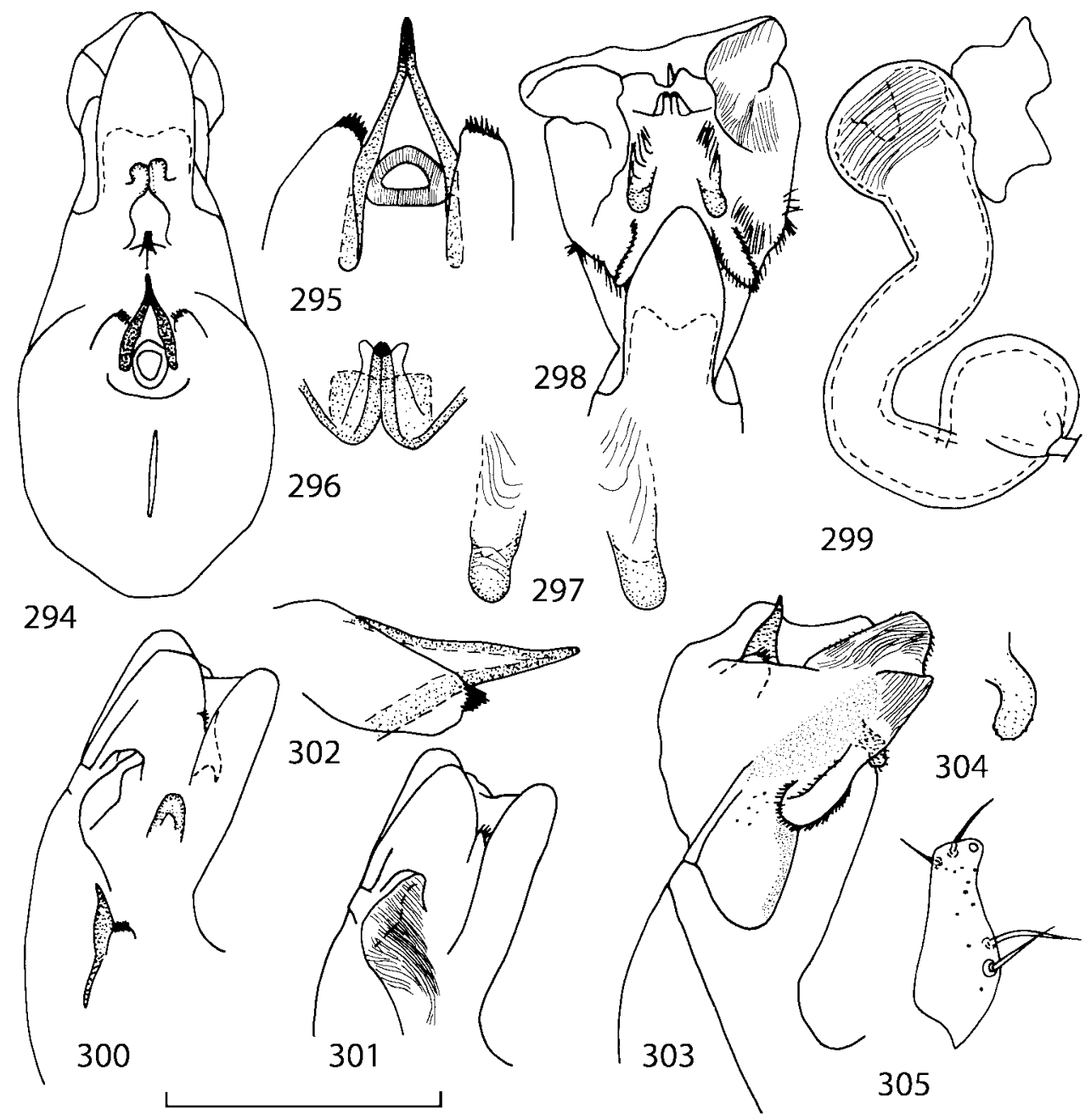

FIGURES 294-305. Genitalia of Geostiba carteriensis Pace (Roan Road Pass, Tennessee / North Carolina). 294 - details of internal sac retracted into median lobe, ventral view; 295 - copulatory piece of internal sac, dorsal view; 296 - medial lamellae of internal sac, ventral view; 297 - distal diverticula of everted internal sac, ventral view; 298 - everted internal sac, ventral view; 299 spermatheca; 300-301 - details of internal sac retracted into median lobe, lateral view; 302 - copulatory piece of internal sac, lateral view; 303 - everted internal sac, lateral view; 304 - right distal diverticulum of everted internal sac, lateral view; 305 - apex of left paramere, side facing median lobe. Scale bar $0.2 \mathrm{~mm}$ (294, 298, 300-301, 303), 0.1 mm (295-297, 299, 302, 304-305). 
Pronotum as wide as long, width $0.40-0.44 \mathrm{~mm}$, wider than head (pronotal width to head width ratio 1.1); microsculpture and puncturation as on head; pronotal pubescence of type V or VI, directed posteriorly in wide medial zone (wider in males), not just along midline. Elytra measured from humeral angle shorter than pronotum (pronotal length to elytral length ratio 1.3), wider than long (1.5), with fine isodiametric microsculpture and fine asperate puncturation, distance between punctures equals 2-3 times their diameter. Elytral suture behind scutellum very slightly raised. Wings reduced to short vestiges, shorter than elytra.

Abdominal terga with fine microsculpture of transverse meshes, with fine and sparse puncturation, puncturation becoming finer towards abdomen apex, on terga 3-5 distance between punctures equals 2-5 times their diameter. Tergum 7 without white edge.

Males with stronger impression on disc of head and along midline of pronotum than females. Male tergum 7 without carinae. Posterior margin of male tergum 8 slightly convex (Fig. 284). Posterior margin of male sternum 8 convex (Fig. 285).

Posterior margin of female tergum 8 convex (Fig. 286). Posterior margin of female sternum 8 concave medially (Figs. 287-288).

Aedeagus as in Figs. 289-298, 300-305. Apex of median lobe in lateral view strait (Figs. 292-293), in ventral view apex outline strongly emarginate basally (Figs. 289-291). Distal diverticula of internal sac narrow (Figs. 297-298, 304).

Spermatheca as in Fig. 299.

Distribution and variability. Known only from the Big Bald in the Bald Mountains massif and from Roan Mountains (Figs. 338-339). Specimens from the Big Bald and from Roan High Knob (the type locality) slightly differ in the shape of the apex of median lobe (Figs. 289-290) and may deserve to be interpreted as distinct taxa. More samples from the adjacent mountains (especially north of Roan Mountains) are necessary to resolve this problem.

Natural History. Geostiba carteriensis was collected in forest litter at altitudes above $1600 \mathrm{~m}$ in leaf litter of coniferous forest with red spruce (Picea rubens) and in the soil of a mountain meadow (a "bald").

\section{Geostiba (Sibiota) impressula (Casey, 1906), sp. propr. (Figs. 306-320)}

Sibiota impressula Casey, 1906: 350.

Sipalia fossata Casey, 1910: 167, syn. nov.

Sipalia (s. str.) impressula: Fenyes, 1920: 251 (as valid species).

Sipalia (s. str.) fossata: Fenyes, 1920: 251 (as valid species).

Sipalia (s. str.) impressula: Bernhauer \& Scheerpeltz, 1926: 601 (as valid species).

Sipalia (s. str.) fossata: Bernhauer \& Scheerpeltz, 1926: 601 (as valid species).

Sibiota impressula: Seevers, 1978: 262 (as valid species).

Sibiota fossata: Seevers, 1978: 262 (as valid species).

Geostiba impressula: Lohse \& Smetana, 1988: 270 (as synonym of Geostiba circellaris (Gravenhorst); misidentification).

Geostiba fossata: Lohse \& Smetana, 1988: 270 (as valid species). 
Type material. Holotype of Sibiota impressula, ․, "Portland, Oreg.[on]", "Sibiota impressula Csy.", "Casey bequest 1925", “TYPE USNM 39028” (NMNH).

Lectotype of Sipalia fossata (here designated), ox, "Lane Co., Or.[egon]", "fossata Csy.", "Casey bequest 1925", "TYPE USNM 39029" (NMNH). The purpose of the lectotype designation is to assure correct and consistent application of the name in the future.

Additional material. UNITED STATES: Oregon: + , Portland $\left[45.5^{\circ} \mathrm{N} 122.7^{\circ} \mathrm{W}\right]$ (Wickham) (CASC); 주, 2우우, without locality data (Koebele) (CASC); Lane Co.: 17

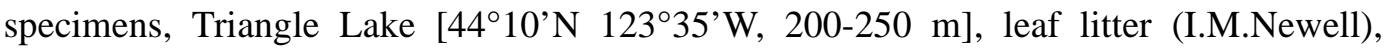
13.iv.1947 (AMNH, KSEM, SPSU).

Diagnosis. Geostiba impressula can be distinguished from other Nearctic species of Geostiba by having large eyes (temple length to eye length ratio 1.8-2.5), pronotal pubescence of type VI, reduced wings, short elytra (pronotum length to elytron length ratio 1.3), the presence of two short parallel carinae in the middle of male abdominal tergum 7 in front of posterior margin, the shape of the aedeagus (Figs. 310-315, 318-319) and the shape of the spermatheca (Figs. 316-317).

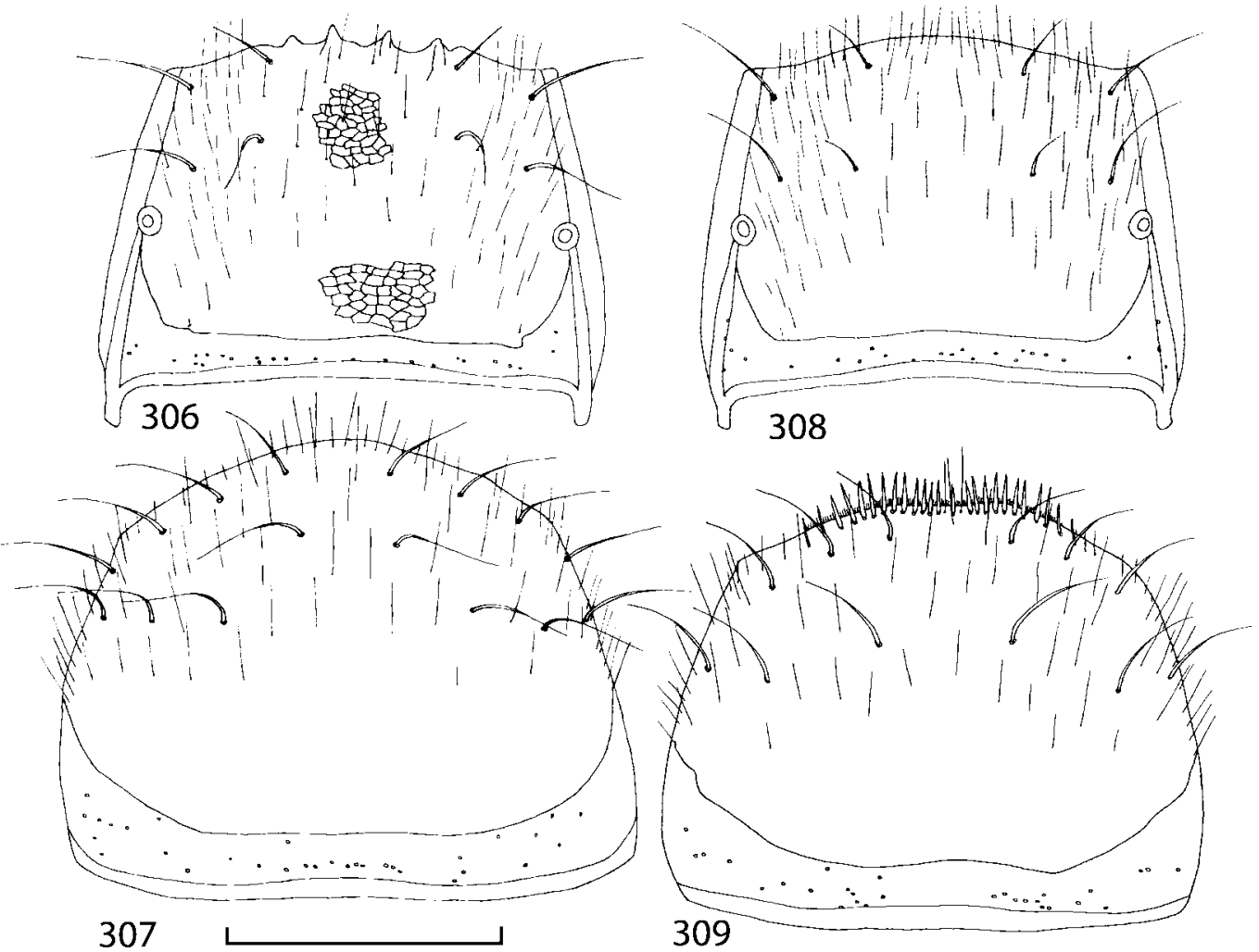

FIGURES 306-309. Abdominal segment 8 of Geostiba impressula (Casey) (Triangle Lake, Oregon). 306 - male tergum $8 ; 307$ - male sternum $8 ; 308$ - female tergum 8; 309 - female sternum 8. Scale bar $0.5 \mathrm{~mm}$. 
Geostiba impressula differs from G. silvigena, another western Nearctic species, in having pronotal pubescence of type VI, reduced wings, shorter elytra, elytral suture behind scutellum flat, strong medial pronotal impression in males, larger aedeagus with the broader apex of the median lobe (in ventral view) (Figs. 310-312, 315, 323-324).

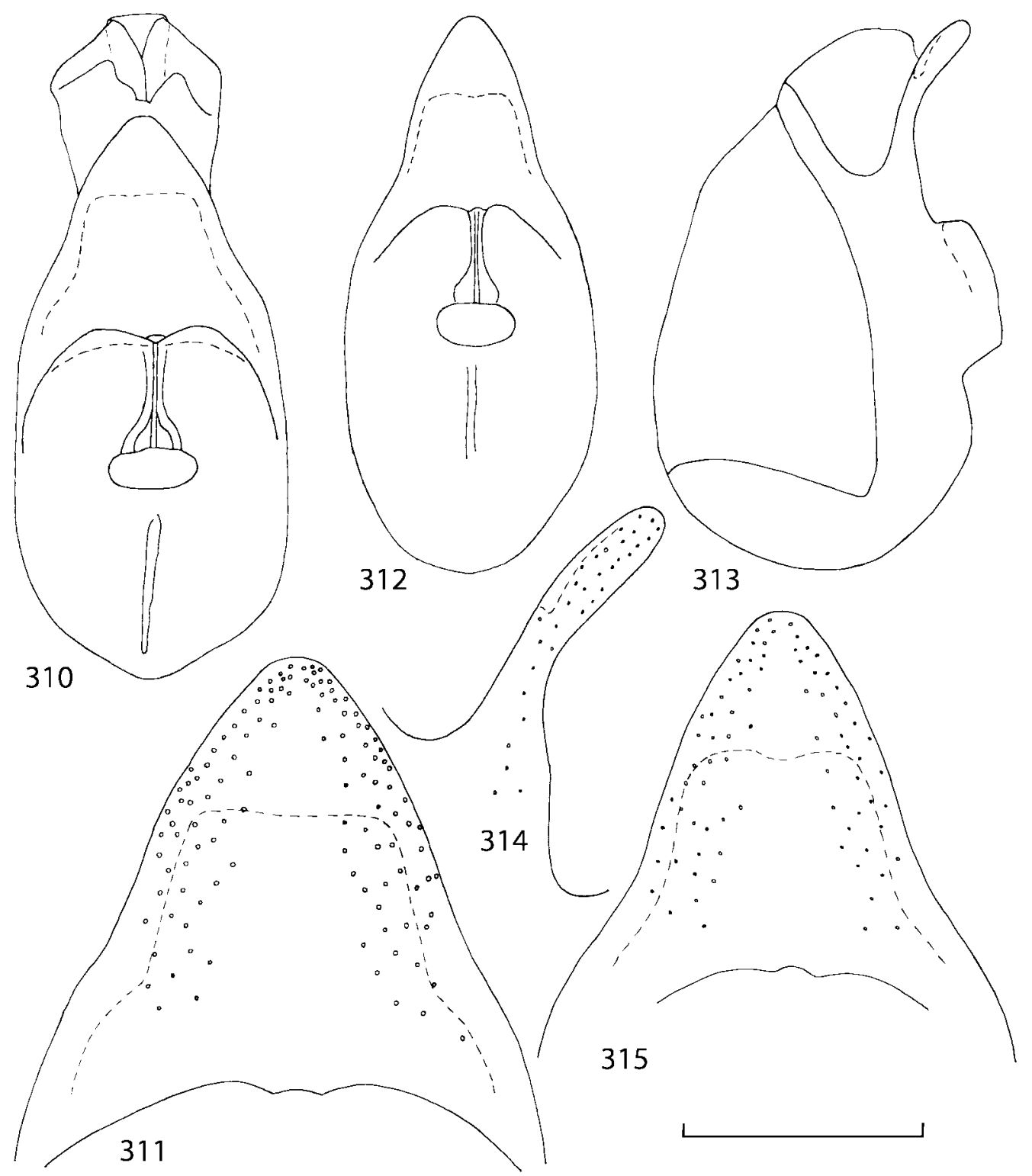

FIGURES 310-315. Aedeagus of Geostiba impressula (Casey) (lectotype of Sipalia fossata Casey (310-311) and a specimen from Triangle Lake, Oregon (312-315)). 310, 312 - median lobe, ventral view; 311,315 - apex of median lobe, ventral view; 313 - median lobe, lateral view; 314 - apex of median lobe, lateral view. Scale bar $0.4 \mathrm{~mm}(310,312-313), 0.2 \mathrm{~mm}(311,314-315)$. 
Description. Length 2.2-2.7 mm. Body reddish brown, sometimes with darker head and abdomen, antennae, legs and mouthparts brownish yellow. Body parallel-sided.

Head as wide as long, surface on disk with fine isodiametric microsculpture, puncturation very fine and weak, distance between punctures equal to 2-4 times their diameter. Temple length to eye length ratio 1.8-2.5. Antennal article 2 longer than article 3 , article 4 slightly transverse (width to length ratio 1.2), articles 5-10 transverse (ratio 1.5-1.6), last article as long as 9 and 10 combined (Fig. 16).

Pronotum slightly transverse, width $0.37-0.50 \mathrm{~mm}$, width to length ratio $1.0-1.1$, wider than head (pronotal width to head width ratio 1.2); microsculpture and puncturation as on head. Pronotal pubescence of type VI. Elytra measured from humeral angle shorter than pronotum (pronotal length to elytral length ratio 1.3), wider than long (1.5), glossy, with traces of weak and fine isodiametric microsculpture and fine asperate puncturation, distance between punctures equals 2-3 times their diameter. Elytral suture not raised behind scutellum. Wings reduced to short vestiges, shorter than elytra.

Abdominal terga with fine microsculpture of transverse meshes, with fine and sparse puncturation, puncturation becoming finer towards abdomen apex, on terga 3-5 distance between punctures equals 3-6 times their diameter. Tergum 7 without white edge.

Males with strong, wide and deep impression along midline of pronotum, the impression becomes deeper and wider posteriorly. In females pronotum flattened along midline. Male tergum 7 with two medial carinae in front of posterior margin. Male tergum 8 with four small carinae in front of posterior margin, posterior margin slightly convex, the carinae protruding posteriorly as four denticles (Fig. 306). Male sternum 8 with convex posterior margin (Fig. 307).

Posterior margin of female tergum 8 convex (Fig. 308). Posterior margin of female sternum 8 slightly concave medially (Fig. 309).

Aedeagus as in Figs. 310-315, 318-320. Apex of median lobe in lateral view bent ventrally (Figs. 312-313), in ventral view apex outline slightly emarginate basally (Figs. 311, 315).

Spermatheca as in Figs. 316-317.

Discussion. Lohse and Smetana (1988) examined the holotype of this species without studying the genitalia and placed G. impressula in synonymy with G. circellaris. My examination of the spermatheca of the holotype of $G$. impressula demonstrates that it has a very different shape in comparison to that of $G$. circellaris. The difference between the males of G. impressula and G. circellaris in the secondary characters and the shape of genitalia is even more significant. Geostiba impressula is therefore a valid species and it is removed from the synonymy with $G$. circellaris.

The type series of Sibiota impressula and Sipalia fossata are represented by a single specimen each, a female and a male, respectively. Because of the sexual dimorphism comparison between these two types alone would not allow to confirm their conspecificity. Fortunately, the big series of specimens from Triangle Lake includes both sexes and both 
types are identical to these specimens in external characters and genitalia. This allows to synonymize the two names.

Distribution. Known from Portland and the Cost Ranges in western Oregon (Fig. 336).

Natural History. Geostiba impressula was collected in forest litter at altitudes up to $250 \mathrm{~m}$.

In June, 2002, I tried in vain to collect additional specimens of this species around Portland and in different localities throughout Oregon, from sea level to $1650 \mathrm{~m}$. The dates and localities provided on the labels of examined specimens of $G$. impressula (April 13; 200-250 m) and G. silvigena (October 1; near sea level), along with the absence of Geostiba specimens in extensive collections made by different staphylinid specialists in summer months seem to indicate that the western Nearctic species of Geostiba are active only during the cooler and wetter time of the year.

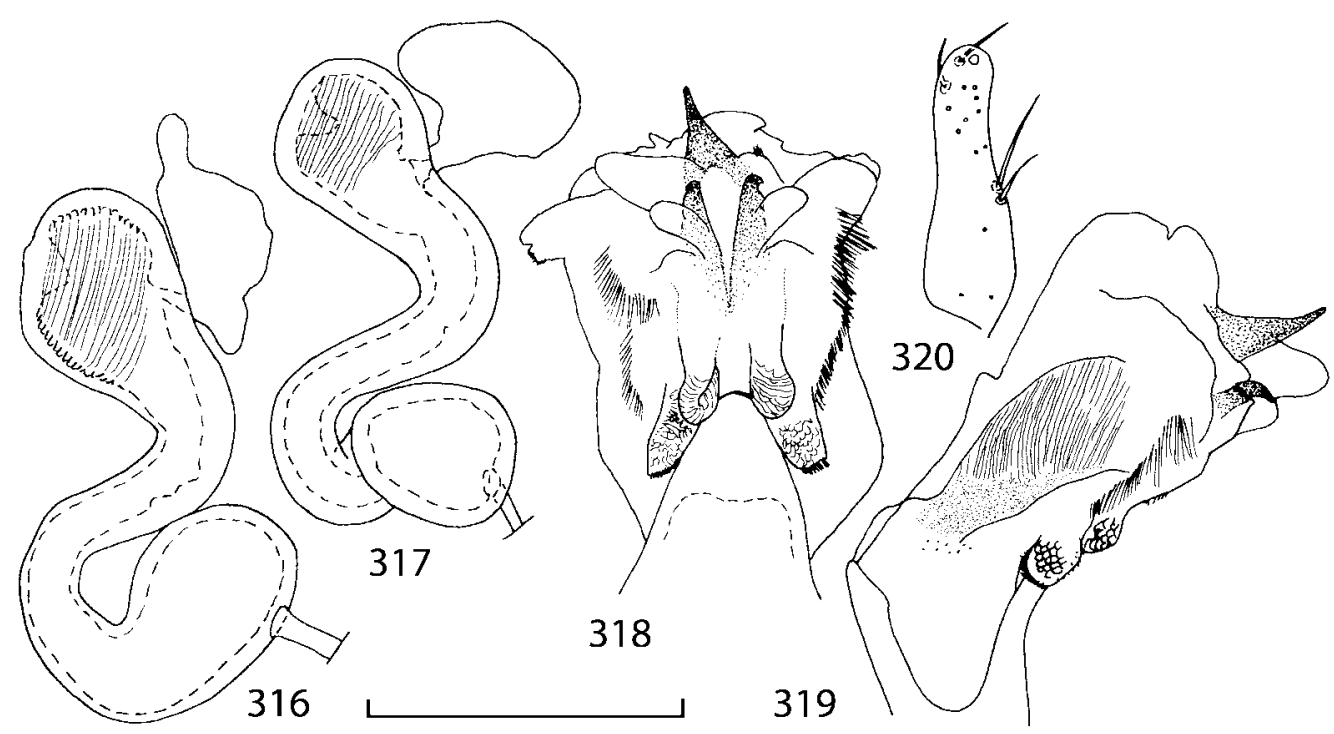

FIGURES 316-320. Genitalia of Geostiba impressula (Casey) (holotype (316) and specimens from Triangle Lake, Oregon (317-320)). 316-317 - spermatheca; 318 - everted internal sac, ventral view; 319 - everted internal sac, lateral view; 320 - apex of left paramere, side facing median lobe. Scale bar $0.2 \mathrm{~mm}(316-317,320), 0.4 \mathrm{~mm}(318-319)$.

14. Geostiba (Sibiota) silvigena Gusarov, sp. n. (Figs. 321-335)

Type material. Holotype, $o^{\star}$, UNITED STATES: California: Mendocino Co.: Mendocino [39 $18^{\circ} 28^{\prime \prime} \mathrm{N} 123^{\circ} 47^{\prime} 53^{\prime \prime} \mathrm{W}$ ], ex moss in bed of dried up woodland pool, Berlese funnel (J.R.Helfer), 1.x.1954 (CNCI). 
Diagnosis. Geostiba silvigena can be distinguished from other Nearctic species of Geostiba by having large eyes (temple length to eye length ratio 2.3), pronotal pubescence of type $\mathrm{V}$, well developed wings, long elytra (pronotum length to elytron length ratio 1.0), the presence of two short parallel carinae in the middle of male abdominal tergum 7 in front of posterior margin, and the shape of the aedeagus (Figs. 323-335).

Geostiba silvigena is very similar to eastern Nearctic G. appalachigena, and differs only in having the apex of median lobe less bent ventrally (in lateral view) (Figs. 325-326, 36-37), and longer and more narrow apex of paramere (Figs. 334, 50).

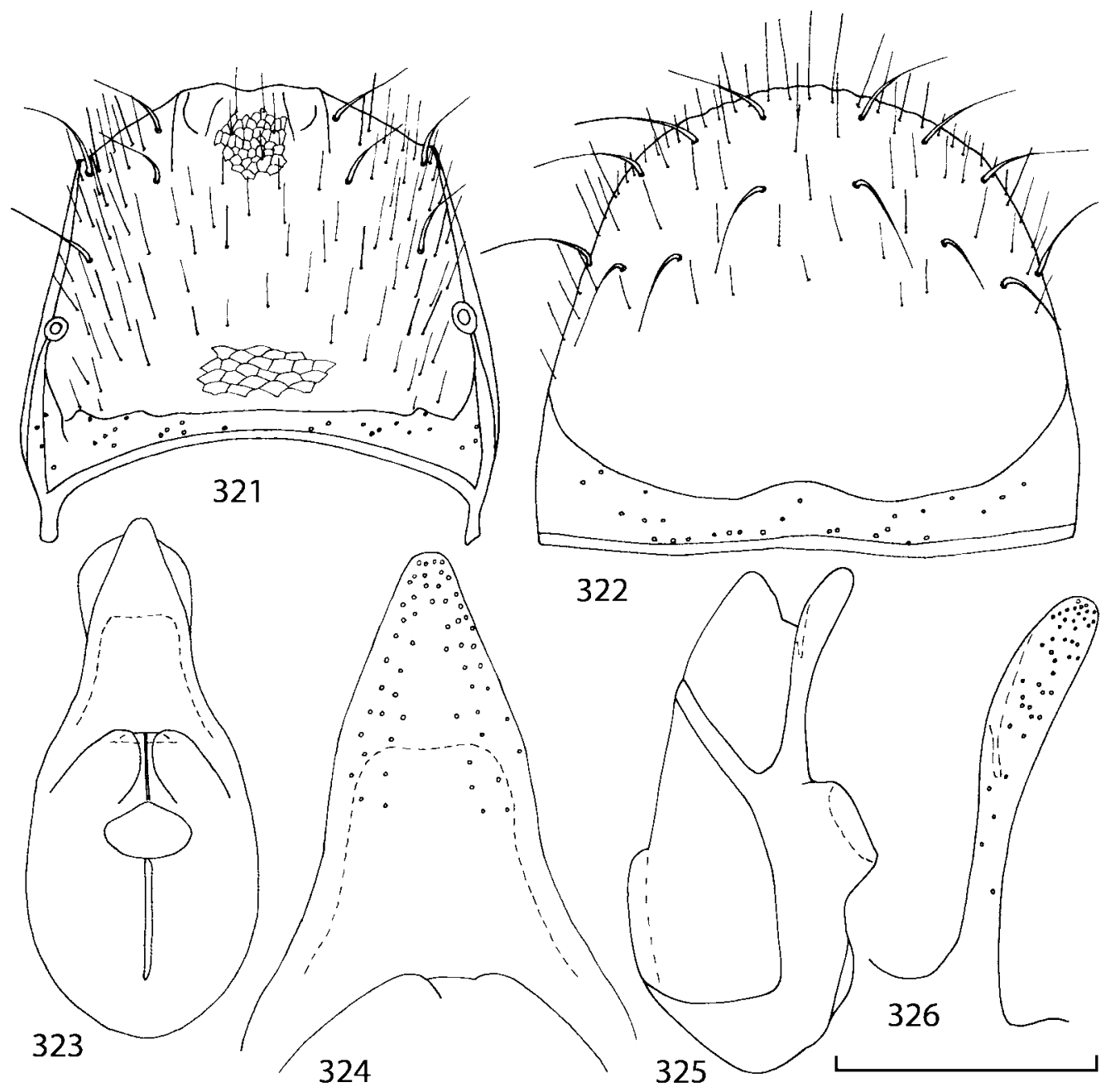

FIGURES 321-326. Abdominal segment 8 and aedeagus of Geostiba silvigena Gusarov, sp. n. (holotype). 321 - male tergum 8; 322 - male sternum 8; 323 - median lobe, ventral view; 324 apex of median lobe, ventral view; 325 - median lobe, lateral view; 326 - apex of median lobe, lateral view. Scale bar $0.4 \mathrm{~mm}(321-323,325), 0.2 \mathrm{~mm}(324,326)$. 
Geostiba silvigena differs from G. impressula, another western Nearctic species, in having pronotal pubescence of type $\mathrm{V}$, well developed wings, longer elytra, aedeagus with more narrow apex of the median lobe (in ventral view) (Figs. 323-324, 310-312, 315), elytral suture slightly raised behind scutellum, and in males lacking the medial pronotal impression.

Description. Length $2.4 \mathrm{~mm}$. Body reddish brown, antennae, legs and mouthparts brownish yellow. Body parallel-sided.

Head as wide as long, surface on disk with fine isodiametric microsculpture, puncturation very fine and weak, distance between punctures equal to 2-3 times their diameter. Temple length to eye length ratio 2.3. Antennal article 2 longer than article 3, article 4 transverse (width to length ratio 1.6), articles 5-10 strongly transverse, last article as long as 9 and 10 combined (as in Fig. 17).

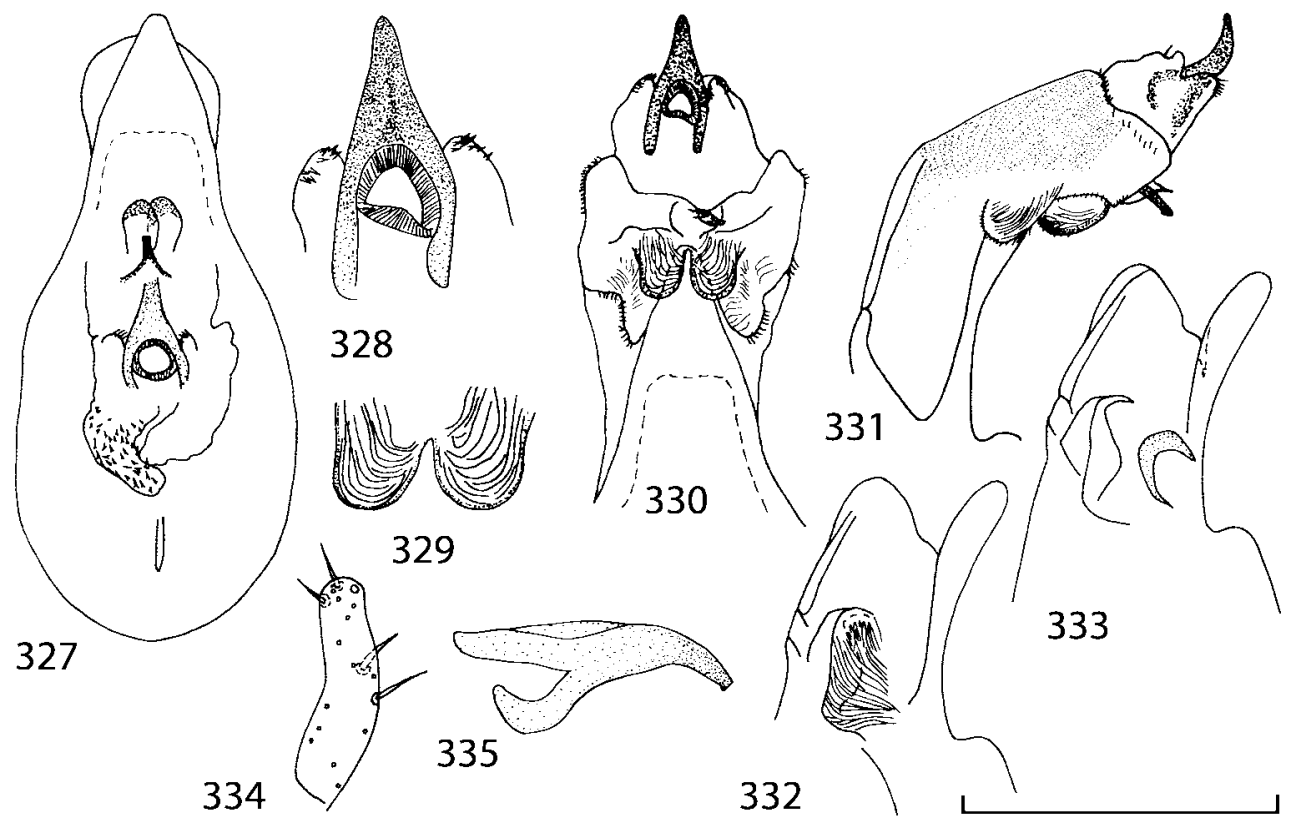

FIGURES 327-335. Genitalia of Geostiba silvigena Gusarov, sp. n. (holotype). 327 - details of internal sac retracted into median lobe, ventral view; 328 - copulatory piece of internal sac, dorsal view; 329 - distal diverticula of everted internal sac, ventral view; 330 - everted internal sac, ventral view; 331 - everted internal sac, lateral view; 332-333 - details of internal sac retracted into median lobe, lateral view; 334 - apex of left paramere, side facing median lobe; 335 - copulatory piece of internal sac, lateral view. Scale bar $0.4 \mathrm{~mm}$ (327, 330-333), $0.2 \mathrm{~mm}$ (328-329, 334-335).

Pronotum slightly transverse, width $0.41 \mathrm{~mm}$, width to length ratio 1.0 , wider than head (pronotal width to head width ratio 1.1); microsculpture and puncturation as on head. Pronotal pubescence of type V. Elytra measured from humeral angle longer than prono- 
tum (pronotal length to elytral length ratio 1.0), wider than long (1.3), with weak and fine isodiametric microsculpture and fine, somewhat asperate puncturation, distance between punctures equals 2-3 times their diameter. Elytral suture behind scutellum raised. Wings fully developed.

Abdominal terga with fine microsculpture of transverse meshes, with fine and sparse puncturation, puncturation becoming finer towards abdomen apex, on terga 3-5 distance between punctures equals 3-5 times their diameter. Tergum 7 with white edge.

Male tergum 7 with two medial carinae in front of posterior margin. Male tergum 8 with four small carinae in front of posterior margin, posterior margin slightly convex (Fig. 321). Male sternum 8 with convex posterior margin (Fig. 322).

Aedeagus as in Figs. 323-335. Apex of median lobe in lateral view bent ventrally (Figs. 325-326), distal diverticula of internal sac in ventral view wide (Figs. 329-330).

Female unknown.

Discussion. Geostiba silvigena has fully developed wings and it is probably widespread along the Pacific coast of North America. The species may not be active in summer when most collections in the area have been made (see the above discussion of natural history of G. impressula). Although G. silvigena is closely related to the eastern Nearctic $G$. appalachigena, the westernmost locality of G. appalachigena is in Wisconsin (Figs. 336337). Considering the gap between the ranges of the two species and the minor difference in male genitalia the separate status of the two seems justified.

Distribution and variability. Known only from Mendocino, California (Fig. 336).

Natural History. The only known specimen of G. silvigena was collected in moss in the bed of a dried up woodland pool.

Etymology. The specific name is derived from the Latin noun silva (forest, woodland) and the verb gigno (to be born, to arise). It refers to the habitat where the species presumably occurs.

\section{Subgenus Geostiba s. str.}

15. Geostiba (s. str.) circellaris (Gravenhorst, 1806) (Figs. 21-23; Figs. 1-4 in Assing (2001))

Aleochara circellaris Gravenhorst, 1806: 155.

Geostiba (s. str.) circellaris: Benick \& Lohse 1974: 112.

Geostiba circellaris: Muona 1984: 229.

Geostiba (s. str.) circellaris: Assing 2001: 139.

Material. CANADA: Newfoundland: $o^{x}, i, \quad S$ Newfoundland, Rencontre West [47.61 $\left.{ }^{\circ} \mathrm{N} 56.69^{\circ} \mathrm{W}\right]$ (Lindroth), 16.vi.1949 (MZHF).

Diagnosis. Geostiba circellaris can be distinguished from other Nearctic species of Geostiba by having large eyes (temple length to eye length ratio 1.6-1.9), pronotal pubes- 
cence of type VI, reduced wings, elytra shorter than pronotum (pronotum length to elytron length ratio 1.1), the presence of one medial carina on male abdominal tergum 7 in front of posterior margin, the shape of the aedeagus and spermatheca (Figs. 1-4 in Assing (2001), Figs. 21-23).

In North America there is no native species closely related to G. circellaris. Geostiba circellaris is superficially similar to G. impressula in having pronotal pubescence of type VI but can be distinguished from the latter species by having tergum 7 with one medial carina in males and a different shape of spermatheca in females (Fig. 4 in Assing (2001), Figs. 316-317).

Description. Length 2.3-2.8 mm. Body reddish brown to brownish black, in some specimens pronotum, elytra and abdominal segments 7-8 lighter, antennae reddish brown to dark brown, legs and mouthparts from brownish yellow to brown. Body parallel-sided.

Head as wide as long, surface on disk with fine isodiametric microsculpture, puncturation very fine, distance between punctures equal to 2-4 times their diameter. Temple length to eye length ratio 1.6-1.9. Antennal article 2 longer than article 3, article 4 subquadrate, articles 5-10 transverse, last article longer than 9 and 10 combined.

Pronotum as wide as long, width $0.43-0.53 \mathrm{~mm}$, wider than head (pronotal width to head width ratio 1.2); surface on disk with fine isodiametric microsculpture, and fine puncturation, distance between punctures equal to 1-2 times their diameter; pronotal pubescence of type VI. Elytra measured from humeral angle shorter than pronotum (pronotal length to elytral length ratio 1.1), wider than long (1.4), with fine isodiametric microsculpture and fine asperate puncturation, punctures stronger than on pronotum, distance between punctures equals 1-2 times their diameter.

Abdominal terga with fine transverse microsculpture, with fine puncturation, puncturation becoming finer towards abdomen apex, on terga 3-5 distance between punctures equals 2-4 times their diameter. Tergum 7 with white edge.

In males pronotum with small medial tubercle at posterior margin (some females have very weak tubercle) and medial impression in front, each elytron with a tubercle near scutellum but distant from elytral suture. Male tergum 7 with one short medial carina in front of posterior margin. Male tergum 8 with two weak and short parallel carina in front of middle of convex posterior margin. Male sternum 8 with posterior margin convex, extending posteriorly beyond tergum.

Aedeagus as in Figs. 1-3 in Assing (2001). Internal sac of aedeagus with one pair of large diverticula (Figs. 21-22).

Posterior margin of female tergum 8 convex. Posterior margin of female sternum 8 distinctly convex, without emargination.

Spermatheca as in Fig. 4 in Assing (2001).

Distribution. Geostiba circellaris is a widespread Palaearctic species. In the Nearctic region, it is known only from Newfoundland (Muona 1984), where it was introduced from Europe. Contrary to the opinion expressed by Lohse and Smetana (1988) Geostiba 
impressula (Casey, 1906) is not a synonym of G. circellaris (see discussion for G. impressula). Geostiba circellaris is not known from western North America.

\section{Geographical distribution of Nearctic Geostiba}

The genus Geostiba currently includes about 350 described species and subspecies distributed in the Palaearctic, Oriental and Nearctic regions. Geostiba is most diverse in the west Palaearctic region while only 15 species occur in North America. Phylogenetic analysis of the Nearctic Geostiba is outside the scope of the present paper and can be completed after representatives of the Palaearctic lineages are included in the analysis.

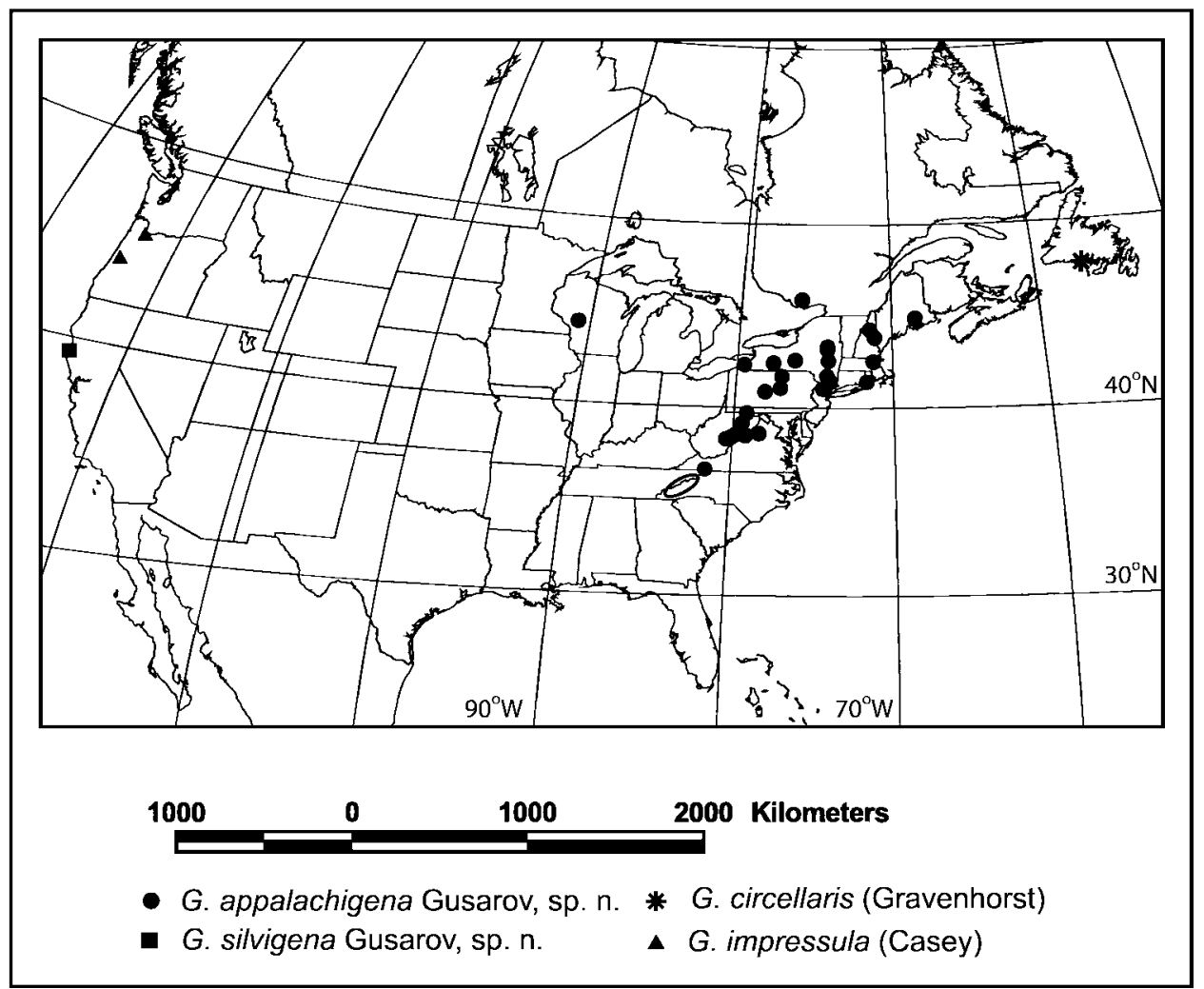

FIGURE 336. Geographical distribution of Nearctic species of Geostiba. The ellipse indicates the area where eleven Southern Appalachian species are distributed.

As a preliminary step, based mostly on similarity of male genitalia, the native Nearctic Geostiba can be divided into several groups: Impressula group (G. impressula), Appalachigena group (G. appalachigena, G. silvigena), Bicarinata group (G. bicarinata, G. graveyardensis), Nimbicola group (G. nimbicola, G. pluvigena, G. nebuligena, G. crepusculigena), Nubigena group (G. balsamensis, G. nubigena, G. coeligena) and Alticola group (G. alticola, G. carteriensis). The only known species of the Impressula group 
occurs in Oregon. The Appalachigena group includes two species with fully developed wings: G. appalachigena, widely distributed in the eastern North America, and G. silvigena, known from a single locality in California (Figs. 336-337). The four remaining groups are restricted to the Southern Appalachians (Figs. 336-340) and their distribution is discussed below in more details.

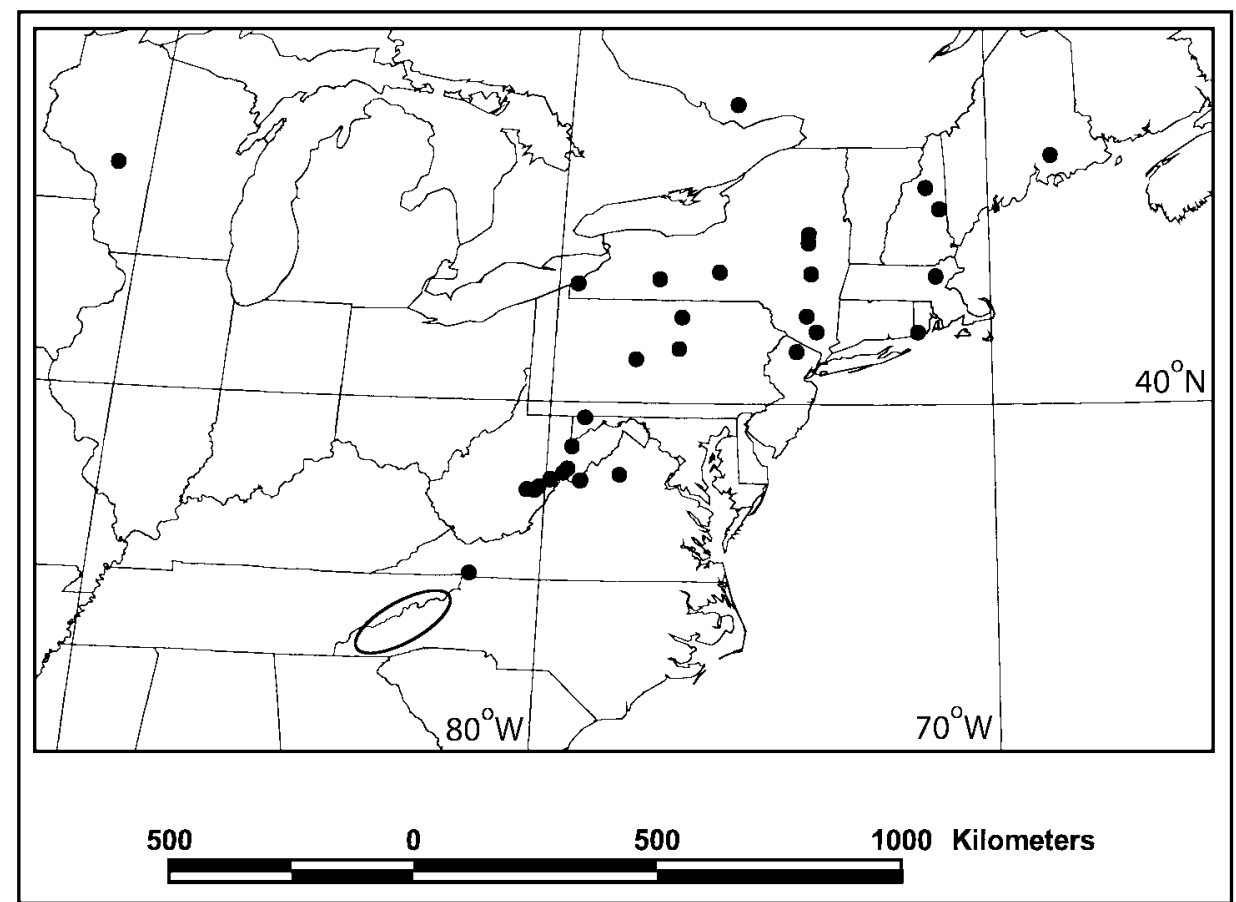

FIGURE 337. Geographical distribution of Geostiba appalachigena Gusarov, sp. n. The ellipse indicates the area where eleven Southern Appalachian species are distributed.

In the Southern Appalachian Mountains, all species of Geostiba are restricted in their distribution to areas above $1200 \mathrm{~m}$ and more commonly occur at altitudes above $1500 \mathrm{~m}$ (Figs. 338-340). Distribution of Geostiba correlates highly with that of red spruce (Picea rubens) and Fraser's fir (Abies fraseri). Specimens of Geostiba were collected in forest litter in all localities where spruce or fir occur, except a few areas with isolated conifer trees scattered in deciduous forest. When the leaf litter in conifer forest is humid the population density of Geostiba is usually high, and a few handfuls of litter are sufficient to get a representative sample. When the forest floor is dry, the beetles become rare and may be totally absent in the samples. Occasionally, few specimens of Geostiba were collected in forest with hemlock, oak, beech, birch, rhododendron and mountain laurel (Kalmia latifolia). In such forests without spruce and fir, the abundance of Geostiba is usually low and sifting large volumes of litter yields very few specimens. This makes it difficult to sample Geostiba in less favorable habitats or alternatively to prove that Geostiba is absent in a 
certain locality. Besides spruce and fir, good indicators of the possible presence of Geostiba include wood-shamrock (Oxalis acetosella) and wild Lily of the Valley (Maianthemum canadense). Interestingly, Geostiba does not descend into ravines where hemlock, another conifer tree, may be common along the creeks down to $500 \mathrm{~m}$.

In the Southern Appalachians, the areas above $1200 \mathrm{~m}$ and available to Geostiba form several clusters separated by valleys of different depth and width. The valleys act as barriers of varying efficiency. This efficiency may have varied with the fluctuating climate during the Pleistocene.

In three massifs in the Southern Appalachians (the Great Smoky Mountains, the Cataloochee Divide - Plott Balsams and the Great Balsam Mountains - Pisgah Ridge), two sympatric species of Geostiba were often collected in the same sample. Even small and isolated Little Pisgah Mountain supports two species of Geostiba (Figs. 338, 340). These observations suggest that in the massifs with only one species of Geostiba present, the distribution pattern is shaped more by barriers than by interspecific competition.

One very effective barrier is the broad Asheville basin between the Bald Mountains massif to the north, the Great Craggy Mountains - Black Mountains massif to the northeast and the mountains to the southwest. The deepest areas are along the French Broad River, with an altitude of about $600 \mathrm{~m}$ south of the Great Craggies and about $440 \mathrm{~m}$ where it cuts through the Bald Mountains. This barrier is old enough to allow the species of the Alticola group to evolve. When the vegetation belts shifted lower during the last glaciation, the barrier was still effective, because it prevented the southern species from colonizing the mountains to the north and prevented the species of the Alticola group from reaching the Pisgah Ridge and the Great Smoky Mountains massif.

The Great Craggy Mountains - Black Mountains massif (inhabited by G. alticola) is separated from the Roan Mountains and the Bald Mountains (inhabited by G. carteriensis) by valleys about $850 \mathrm{~m}$ deep. This wide barrier is more effective than the deeper (about $600 \mathrm{~m}$ ) but more narrow valley of the Nolichuky River separating the Big Bald and the Roan populations of G. carteriensis. It is not clear why G. appalachigena, a widespread winged species occurs in the Mount Rogers massif but does not reach the Roan Mountains, which are connected to Mount Rogers by a series of high mountains interrupted by relatively high valleys (about $900 \mathrm{~m}$ at the deepest). Additional collecting is needed in this area.

Both vicariance and dispersal must have occurred in the southern species groups (Bicarinata, Nimbicola and Nubigena groups) which have sympatric species in many massifs. In comparison to other groups, the members of Nubigena group are the more advanced in adaptation to a cryptic life style. The Nubigena group also has a wider distribution than the Nimbicola and Bicarinata groups (it is represented in the Great Smoky Mountains massif, the Cataloochee - Plott Balsams massif, the Great Balsam Mountains Pisgah Ridge massif and in the Nantahala Mountains massif). Therefore, it seems likely that the Nubigena group is the oldest among the three species groups. 


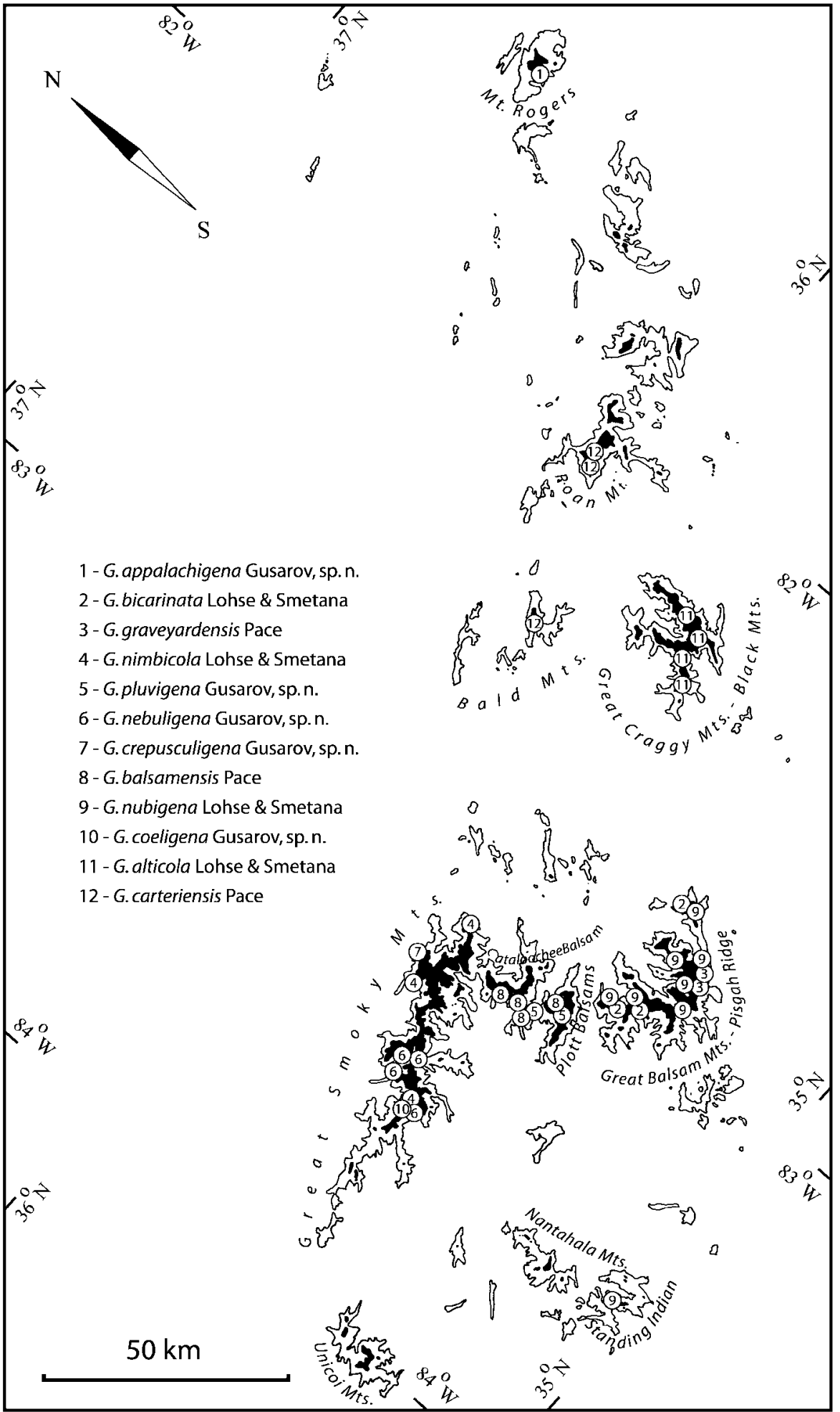

FIGURE 338. Geographical distribution of twelve species of Geostiba in the Southern Appalachians. Isohypses $1200 \mathrm{~m}$ and $1500 \mathrm{~m}$ are shown. Areas above $1500 \mathrm{~m}$ are solid black. 


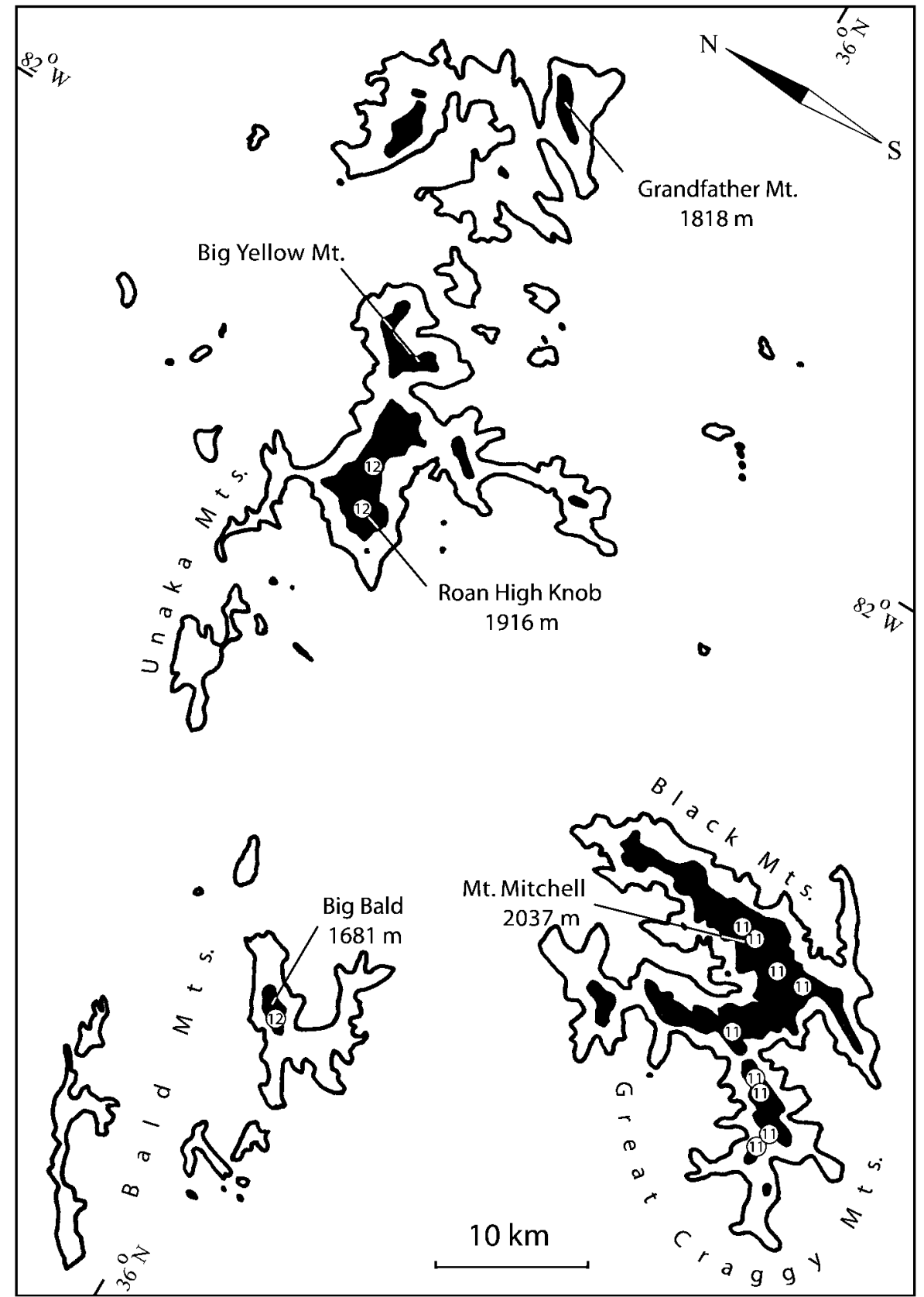

FIGURE 339. Detailed geographical distribution of Geostiba alticola Lohse \& Smetana (11) and G. carteriensis Pace (12) in the Southern Appalachians. Isohypses $1200 \mathrm{~m}$ and $1500 \mathrm{~m}$ are shown. Areas above $1500 \mathrm{~m}$ are solid black.

The Bicarinata species group evolved in isolation in the Great Balsam Mountains Pisgah Ridge massif. This massif is isolated from the Plott Balsams by the Balsam gap $(1027 \mathrm{~m})$, which prevented the species of Bicarinata group from dispersing westwards. Apparently both speciation and dispersal has occurred within the massif, because G. bicar- 
inata occurs in the western (Richland Balsam) and eastern (Little Pisgah Mountain) portions of the massif with G. graveyardensis in between (Graveyard Ridge and Black Balsam Knob).

The Nimbicola group evolved in isolation in the Great Smoky Mountains and Cataloochee - Plott Balsams massifs, where four species occur. The second of these massifs is populated by $G$. pluvigena, a species very closely related to $G$. nimbicola. One can hypothesize that the gap (about $1340 \mathrm{~m}$ ) between the Mount Sterling Ridge and Cataloochee Balsam was the barrier which allowed this divergence. Interestingly, the Soco Gap (1323m) between the Plott Balsams and the Cataloochee Divide did not trigger speciation: the specimens from Waterrock Knob and Cataloochee Balsam are identical. The Great Smoky Mountains massif has not been sampled adequately yet.

My attempts to collect Geostiba were unsuccessful in several mountain massifs. It is certainly harder to demonstrate the absence of a species than its presence. Nevertheless, some of my negative results are listed below.

Geostiba was not found in the Unicoi Mountains (the highest point is Haw Knob, 1668 $\mathrm{m})$, even in forest with red spruce present. The Unicoi Mountains are separated from the Great Smoky Mountains by the deep $(400 \mathrm{~m})$ valley of the Little Tennessee River which may have prevented the dispersal of Geostiba from the Great Smokies. However, the Unicois are connected to the Nantahala Mountains (where G. nubigena was collected) and the deepest gap between them is about $800 \mathrm{~m}$ high (the divide between the Valley River and the Nantahala River). The Nantahalas are connected with the Pisgah Ridge massif by the Blue Ridge, with the deepest gap of about $640 \mathrm{~m}$ being the valley of the Little Tennessee River. Geostiba nubigena found near the Standing Indian summit occurs on both sides of this gap. One can predict that if any species of Geostiba are found in the Unicois they will be more closely related to the species represented in the Great Balsam Mountains - Pisgah Ridge massif than to the species of the Great Smoky Mountains massif.

Geostiba was not found on Wayah Bald (1628 m) and Wine Spring Bald (1585 m, red spruce present); both summits have been greatly affected by humans.

Geostiba was not found in the Bald Mountains south of the Broad French River. The highest summit (Max Patch Mountain, $1411 \mathrm{~m}$ ) was deforested many decades ago and used for horse grazing, perhaps resulting in the extinction of Geostiba in this locality.

The results presented above are preliminary and more detailed discussion will follow after phylogenetic analysis of the Nearctic Geostiba is done and more samples taken. However, it is still interesting to compare distribution patterns of Geostiba and the carabid genus Trechus Clairville 1806 (Barr 1962, 1969, 1979, 1985; Kane et al. 1990), represented in the Southern Appalachians by many endemic forms restricted to high altitudes.

Geostiba is not as diverse as Appalachian Trechus, with more than 50 species and subspecies described. In the Southern Appalachians, Geostiba was not found on some of the mountains where endemic forms of Trechus occur. However, the distribution observed in Geostiba also agrees with the theory that the species ranges expanded during the glacial 
periods and contracted in warmer interglacial periods. As in Trechus, in Geostiba the number of species in a massif correlates with the area of the land above $1200 \mathrm{~m}$. The Asheville basin was even more effective a barrier for Geostiba than for Trechus, in which the members of Vandykei group occur on both sides of the basin.

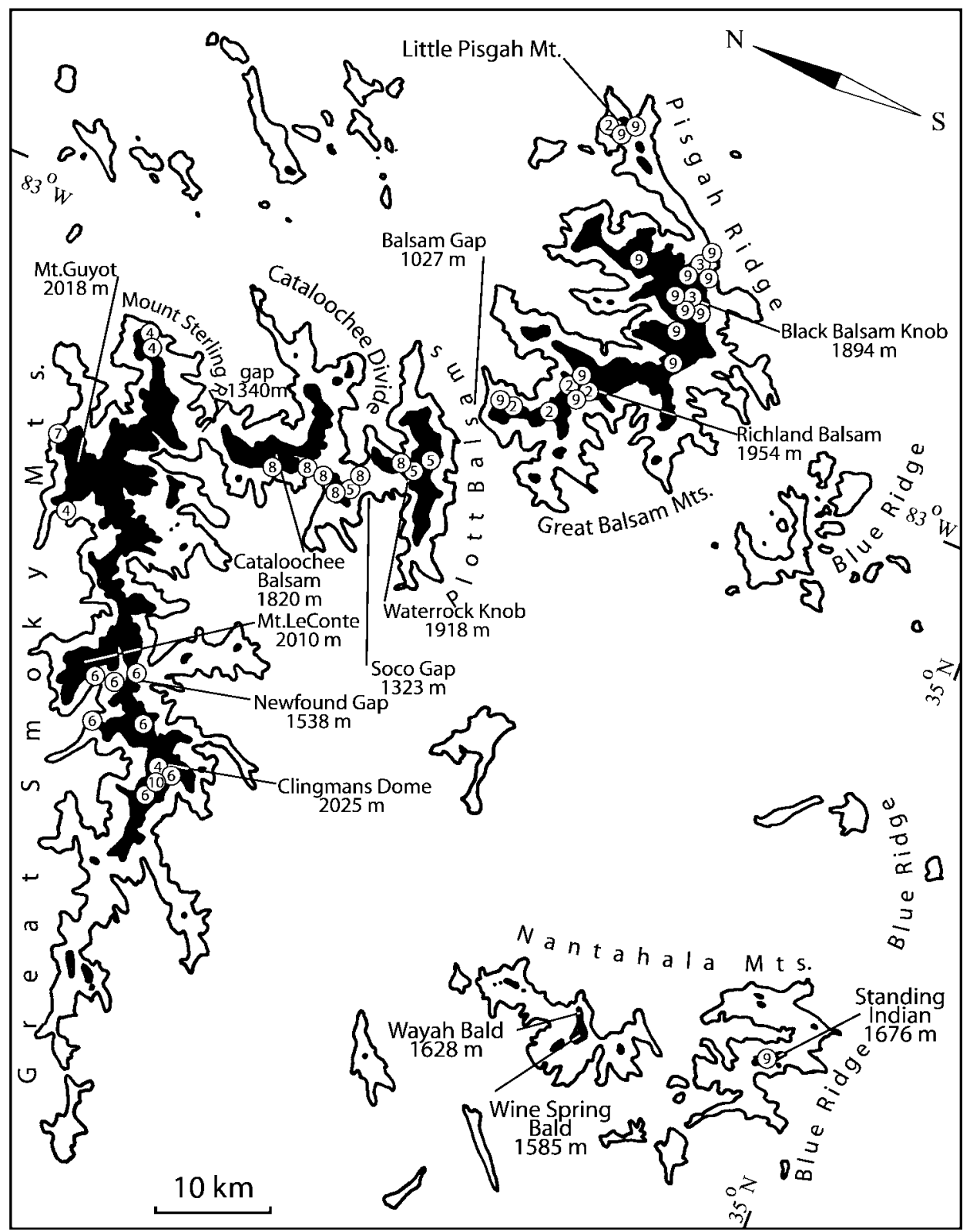

FIGURE 340. Detailed geographical distribution of Geostiba bicarinata Lohse \& Smetana (2), G. graveyardensis Pace (3), G. nimbicola Lohse \& Smetana (4), G. pluvigena Gusarov, sp. n. (5), G. nebuligena Gusarov, sp. n. (6), G. crepusculigena Gusarov, sp. n. (7), G. balsamensis Pace (8), G. nubigena Lohse \& Smetana (9), G. coeligena Gusarov, sp. n. (10) in the Southern Appalachians. Isohypses $1200 \mathrm{~m}$ and $1500 \mathrm{~m}$ are shown. Areas above $1500 \mathrm{~m}$ are solid black. 
The summits of the higher mountains in the Southern Appalachians support many relict species that do not descend into the valleys. Unfortunately, many summits have been used to build parking lots for tourists visiting the overlooks (Reddish Knob, Wayah Bald, Mount Mitchell) or radio transmitters with supporting facilities (Wine Spring Bald, Little Pisgah Mountain). Often the original vegetation of these summits is greatly disturbed or even completely eradicated. In the case of Geostiba, the isolated summits with a small area that are above $1500 \mathrm{~m}$ are especially vulnerable because they do not have enough space to support both a parking lot for visitors and a patch of conifer trees. In my opinion, special measures should be taken to protect the endemic fauna at such locations.

\section{Synonymic notes}

The generic names Typhlusida Casey, 1906 and Sipaliella Casey, 1911 were considered by different staphylinid specialists as synonyms of Geostiba, as valid subgenera of Geostiba, or as separate and valid genera closely related to Geostiba. It seems appropriate to discuss the status of these two names below.

\section{Geostiba (Typhlusida Casey, 1906)}

Typhlusida Casey, 1906: 263 (Type species: Sipalia flava Kraatz, 1856, by original designation) (as genus in subtribe Bolitocharina Thomson, 1859).

Typhlusida: Fenyes, 1920: 249 (as synonym of Sipalia Mulsant \& Rey, 1853).

Typhlusida: Bernhauer \& Scheerpeltz, 1926: 599 (as synonym of Sipalia).

Tylosipalia Scheerpeltz, 1951: 174 (Type species: Sipalia flava Kraatz, 1856, by original designation) (as subgenus of Sipalia).

Typhlusida: Blackwelder, 1952: 163 (as synonym of Evanystes Gistel, 1856).

Typhlusida: Seevers, 1978: 126 (as synonym of Geostiba).

Typhlusida: Lohse, 1989: 209 (as subgenus of Geostiba).

Tylosipalia: Lohse, 1989: 209 (as synonym of Typhlusida).

Typhlusida: Ashe in Newton, Thayer, Ashe \& Chandler, 2000: 371 (as synonym of Geostiba).

By original designation Sipalia flava (Kraatz, 1856) is the type species of both Typhlusida and Tylosipalia. Consequently, Tylosipalia is a junior objective synonym of Typhlusida. This synonymy was established by Lohse (1989) but overlooked by Ashe (Newton et al., 2000). Typhlusida is a valid subgenus of Geostiba and includes 13 west Palaearctic species.

\section{Meotica Mulsant \& Rey, 1873}

Meotica Mulsant \& Rey, 1873: 174 (Type species: Meotica parasita Mulsant \& Rey, 1873, by subsequent designation (Blackwelder 1952)). 
Sipaliella Casey, 1911: 159 (Type species: Sipalia filaria Casey, 1911, by monotypy) (as subgenus of Sipalia Mulsant \& Rey, 1853), syn. nov.

Sipaliella: Fenyes, 1920: 252 (as subgenus of Sipalia).

Sipaliella: Bernhauer \& Scheerpeltz, 1926: 603 (as subgenus of Sipalia).

Sipaliella: Blackwelder, 1952: (as subgenus of Evanystes Gistel, 1856).

Sipaliella: Seevers, 1978: 129 (as valid genus in subtribe Geostibina Seevers, 1978).

Sipaliella: Ashe in Newton, Thayer, Ashe \& Chandler, 2000: 371 (as valid genus in subtribe Geostibina Seevers, 1978).

Because Sipalia filaria Casey, 1911, the type species of Sipaliella, is conspecific with Meotica pallens (Redtenbacher) (see below), a species known from Europe, the name Sipaliella is here placed in synonymy with Meotica. Meotica pallens is only superficially similar to Geostiba in having small eyes and short elytra and belongs to a different tribe (Oxypodini Thomson, 1859).

Two other European species of Meotica recorded in North America are M. exilis (Knoch in Gravenhorst, 1806) (Bernhauer \& Scheerpeltz 1926; Seevers 1978) and M. apicalis G.Benick, 1953 (Muona 1984). The latter record is not reflected in the recently published guide to North American staphylinids (Newton et al. 2000). Because M. exilis had been recorded in North America before the revision of Meotica was published (Muona 1991), the record requires reconfirmation.

The species of Meotica have the tarsal formula 5-5-5 and the genus appears in Key B for the aleocharine genera by Ashe (Newton et al. 2000). The entry for Sipaliella should be deleted from Key J, and the couplets 26 and 27 can be replaced by the following single couplet:

26(21) Elytra distinctly longer than pronotum 28

- $\quad$ Elytra subequal to, or shorter than pronotum 29

\section{Meotica pallens (Redtenbacher, 1849)}

Homalota pallens Redtenbacher, 1849: 662.

Sipalia (Sipaliella) filaria Casey, 1911: 159, syn. nov.

Meotica pallens: Muona, 1991: 228.

(Other references are omitted)

Type material. Holotype, $\sigma^{x}$, “ R[hode].I[sland].[According to Casey Locality Code (Buchanan 1935; FitzGerald 1962) the black dot inside the upper part of the letter "R" stands for Casey farm, Boston Neck, N. Kingston]", "Sipaliella filaria Csy.", "Casey bequest 1925", “TYPE USNM 39031” (NMNH).

Additional material. UNITED STATES: New Jersey: Warren Co.: 우, $24 \mathrm{~km} \mathrm{NW}$ Hackettstown, Dunnfield Creek National Area, 4058.33'N 7507.49'W, 20 m (V. Gusarov), 5.iv.1999 (SPSU). 
Discussion. The holotype of S. filaria completely corresponds to European specimens of M. pallens and redescription by Muona (1991). Apparently this species has been introduced from Europe.

\section{Acknowledgements}

I am grateful to Terry Erwin and Dave Furth, National Museum of National History, for loan of the Casey Collection of Aleocharinae. This, and other studies of North American Aleocharinae, would not be possible without daily access to this collection. I am greatly indebted to Aleš Smetana, Anthony Davies, Lee Herman, Alfred Newton, Philip Parrillo, David Kavanaugh, Roberta Brett, Jyrki Muona and Hans Silfverberg for the loan of Geostiba specimens. I thank Keith Langdon of the Great Smoky Mountains National Park and Chris Ulrey of the Blue Ridge Parkway for allowing me to collect specimens in the parks. I am grateful to Zack Falin and the anonymous reviewers for their comments which helped to improve my manuscript. Alexandria Digital Library Gazetteer Server (http://fatalbert.alexandria.ucsb.edu:8827/gazetteer/) was used to find coordinates for some localities. This work was supported by National Science Foundation PEET grants DEB9521755 and DEB-9978110 to Steve Ashe, by Lincoln Elsworth Postdoctoral Research Fellowship at the American Museum of Natural History and by Russian Federal program "Universities of Russia - Fundamental Sciences" (Project 07.01.056).

\section{References}

Assing, V. (1999) A revision of the species of Geostiba Thomson 1858 from Greece and Cyprus (Coleoptera, Staphylinidae, Aleocharinae). Linzer biologische Beiträge, 31(2), 845-928.

Assing, V. (2000) On some species of Geostiba Thomson, 1858 from the eastern Alps (Coleoptera: Staphylinidae, Aleocharinae). Koleopterologische Rundschau, 70, 79-85.

Assing, V. (2001) A revision of the Turkish species of Geostiba Thomson 1858 and Tropimenelytron Pace 1983 (Coleoptera: Staphylinidae, Aleocharinae). Linzer biologische Beiträge, 33(1), 137-185.

Barr, T.C. (1962) The genus Trechus (Coleoptera: Carabidae: Trechini) in the southern Appalachians. The Coleopterists Bulletin, 16, 65-92.

Barr, T.C. (1969) Evolution of the (Coleoptera) Carabidae in the Southern Appalachians. In: Holt, P.C., Hoffman, R.L. \& Hart, C.W. (Eds.), The Distributional History of the Biota of the Southern Appalachians. Part I: Invertebrates. Research Division Monograph. Blacksburg: Virginia Polytechnic Institute, pp. 67-92.

Barr, T.C. (1979) Revision of Appalachian Trechus (Coleoptera: Carabidae). Brimleyana, 2, 29-75.

Barr, T.C. (1985) Pattern and process in speciation of trechine beetles in eastern North America (Coleoptera: Carabidae: Trechinae). In: Ball, G.E. (Ed.), Taxonomy, Phylogeny and Zoogeography of Beetles and Ants. Dordrecht: Dr W.Junk Publishers, pp. 350-407.

Benick, G. (1981) Neue Atheten (Col., Staphylinidae) aus dem Muséum d'Histoire naturelle in Genf. Revue suisse de Zoologie, 88(1), 297-307.

Benick, G. \& Lohse, G.A. (1974) 14. Tribus: Callicerini (Athetae). In: Freude, H., Harde, K.W. \& Lohse, G.A. (Eds.), Die Käfer Mitteleuropas. Band 5, Staphylinidae II (Hypocyphtinae und 
Aleocharinae). Pselaphidae. Krefeld: Goecke \& Evers Verlag, pp. 72-220.

Bernhauer, M. (1900) Die Staphyliniden-Gattung Leptusa Kraatz, nebst einer analytischen Bestimmungstabelle der paläarktischen Arten. Verhandlungen der Zoologisch-Botanischen Gesellschaft in Wien, 50, 399-432.

Bernhauer, M. (1905) Neue Aleocharinen aus Nordamerika. Deutsche Entomologische Zeitschrift, 1905, 249-256.

Bernhauer, M. \& Scheerpeltz, O. (1926) Staphylinidae VI. In: Junk, W. \& Schenkling, S. (Eds.), Coleopterorum Catalogus, Pars 82. Berlin: W. Junk, pp. 499-988.

Blackwelder, R.E. (1936) Morphology of the coleopterous family Staphylinidae. Smithsonian Miscellaneous Collections, 94(13), 1-102.

Blackwelder, R. E. (1952) The generic names of the beetle family Staphylinidae, with an essay on genotypy. United States National Museum Bulletin, 200, 1-483.

Brundin, L. (1944) Monographie der palaearktischen Arten der Atheta-Untergattung Hygroecia (Coleoptera, Staphylinidae). Annalen des Naturhistorischen Museums in Wien, [1942] 53(2), 129-300, Taf. xiii-xl.

Buchanan, L.L. (1935) Thomas Lincoln Casey and the Casey Collection of Coleoptera. Smithsonian Miscellaneous Collections, 94(3), 1-15.

Casey, T. L. (1906) Observations on the staphylinid groups Aleocharinae and Xantholinini, chiefly of America. Transactions of the Academy of Science of St.Louis, 16, 125-434.

Casey, T. L. (1910) New Species of the Staphylinid Tribe Myrmedoniini. Memoirs on the Coleoptera I. Lancaster: The New Era Printing Company, pp.1-183.

Casey, T. L. (1911) New American species of Aleocharinae and Myllaeninae. Memoirs on the Coleoptera II. Lancaster: The New Era Printing Company, pp.1-245.

Coiffait, H. (1972) Coléoptères Staphylinidae de la Région Paléarctique Occidentale. I. Généralités. Sous-familles: Xantholininae et Leptotyphlinae. Supplément à la Nouvelle Revue d'Entomologie, 2(2), pp. 1-651.

Fauvel, A. (1902a) Zur Staphyliniden-Fauna von Ceylan, von Dr. Max Bernhauer (Deutsche Entom. Zeits., 1902, Heft I). Revue d'Entomologie, 21, 40-43.

Fauvel, A. (1902b). Catalogue des Staphylinides de la Barbarie, de la Basse-Égypte et des Iles Açores, Madères, Salvages et Canaries ( $5^{\mathrm{e}}$ édition). Revue d'Entomologie, 21, 45-189.

Fenyes, A. (1920) Coleoptera. Fam. Staphylinidae, subfam. Aleocharinae. In: Wytsman, P. (Ed.), Genera Insectorum, Fasc. 173 B. Bruxelles: L. Desmet-Verteneuil, pp. 111-414.

FitzGerald, W. (1962) Casey Locality Code. Manuscript kept with Casey collection. Pp. 1-36.

Fowler, W.W. (1888) The Coleoptera of the British Islands. A descriptive account of the families, genera, and species indigenous to Great Britain and Ireland, with notes as to localities, habitat, etc. Vol. II. Staphylinidae. London: L.Reeve \& Co., 444 pp.

Gistel, J. (1856) Die Mysterien der Europäischen Insectenwelt. Kempten: Drück und Verlag von Tobias Dannheimer. $530 \mathrm{pp}$.

Gravenhorst, J.L.C. (1806) Monographia Coleopterorum Micropterorum. Göttingen: Henricus Dieterich. xvi +248 pp.

Hansen, M. (1997) Phylogeny and classification of the staphyliniform beetle families (Coleoptera). Biologiske Skrifter, 48, 1-339.

ICZN (1999) International Code of Zoological Nomenclature. Fourth Edition. London: The International Trust for Zoological Nomenclature. xxix $+306 \mathrm{pp}$.

Jeannel, R. \& Paulian, R. (1944) Morphologie abdominale des Coléoptères et systématique de l'ordre. Revue française d'Entomologie, 11(2), 65-110.

Kane, T.C., Barr, T.C. \& Stratton, G.E. (1990) Genetic Patterns and Population Structure in Appalachian Trechus of the vandykei Group (Coleoptera: Carabidae). Brimleyana, 16, 133-150.

Kraatz, G. (1856) Naturgeschichte der Insecten Deutschlands. Erste Abteilung. Coleoptera. Bd. 2. Lief. 1-2. Berlin: Verlag der Nicolaischen Buchhandlung, pp. 1-376. 

genitalia in insects. $2^{\text {nd }}$ ed. Copenhagen: Munksgaard, pp. 80-88.

Lohse, G.A. (1974) 11. Tribus: Bolitocharini. In: Freude, H., Harde, K.W. \& Lohse, G.A. (Eds.), Die Käfer Mitteleuropas. Band 5, Staphylinidae II (Hypocyphtinae und Aleocharinae). Pselaphidae. Krefeld: Goecke \& Evers Verlag, pp. 39-63.

Lohse, G.A. \& Smetana, A. (1988) Four new species of Geostiba Thomson from the Appalachian mountains of North Carolina, with a key to North American species and synonymic notes (Coleoptera: Staphylinidae: Aleocharinae). The Coleopterists Bulletin, 42(3), 269-278.

Lohse, G.A. (1989) Ergänzungen und Berichtigungen zu Freude-Harde-Lohse "Die Käfer Mitteleuropas” Band 5 (1974), pp. 185-243 In: Lohse, G.A. \& Lucht, W.H. (Eds.), Die Käfer Mitteleuropas. 1. Supplementband mit Katalogteil. Krefeld: Goecke \& Evers Verlag, pp. 185-243.

Mulsant, E. \& Rey, C. (1853) Description de quelques Coléoptères nouveaux ou peu connus, de la tribu des Brachélytres. Annales de la Société Linnéenne de Lyon, ser. 2, 1, 22-72.

Mulsant, E. \& Rey, C. (1873) Description de divers Coléoptères Brévipennes nouveaux ou peu connus. Opuscules Entomologiques, 15, 147-189.

Muona, J. (1983) Two new palaearctic Atheta species (Coleoptera, Staphylinidae). Annales Entomologici Fennici, 49, 57-58.

Muona, J. (1984) Review of Palaearctic Aleocharinae also occurring in North America (Coleoptera: Staphylinidae). Entomologica scandinavica, 15, 227-231.

Muona, J. (1991) The North European and British species of the genus Meotica Mulsant \& Rey (Coleoptera, Staphylinidae). Deutsche entomologische Zeitschrift, N.F., 38(1-3), 225-246.

Newton, A.F., Thayer, M.K., Ashe, J.S. \& Chandler, D.S. (2000). Staphylinidae Latreille, 1802. In: Arnett, R.H., Thomas, M.C. (Eds.), American Beetles. Vol.1. Archostemata, Myxophaga, Adephaga, Polyphaga: Staphyliniformia. Boca Raton: CRC Press, pp. 272-418.

Pace, R. (1997) Aleocharinae attere del North Carolina, Tennessee e Oregon (Coleoptera, Staphylinidae). Bollettino del Museo Regionale di Scienze Naturali, Torino, 15(1), 101-110.

Redtenbacher, L. (1849) Fauna austriaca. Die Käfer. Wien: C.Gerold, pp. 641-883.

Reitter, E. (1909) Fauna Germanica. Die Käfer des Deutschen Reiches. Nach der analytischen Methode bearbeitet. Bd. 2. Stuttgart: K. G. Lutz, 392 pp.

Sainte-Claire Deville, J. (1906) Catalogue critique des Coléoptères de la Corse. Revue d'Entomologie, 25, 1-136.

Sawada, K. (1970) Aleocharinae (Staphylinidae, Coleoptera) of the IBP-Station in the Shiga Heights, Central Japan (I). Bulletin of the National Science Museum, 13(1), 23-64.

Sawada, K. (1972) Methodological Research in the Taxonomy of Aleocharinae. Contributions from the Biological Laboratory, Kyoto University, 24(1), 31-59.

Scheerpeltz, O. (1934) Staphylinidae VIII. In: Junk, W. \& Schenkling, S. (Eds.), Coleopterorum Catalogus, Pars130. Berlin: W.Junk, pp. 1501-1881.

Scheerpeltz, O. (1951) Die neue Systematik der Gattung Sipalia Muls. Rey (Col. Staphylinidae). Verhandlungen der Zoologisch-botanischen Gesellschaft in Wien, 92, 166-180.

Seevers, C.H. (1978) A generic and tribal revision of the North American Aleocharinae (Coleoptera: Staphylinidae). Fieldiana: Zoology, 71, vi +275 pp.

Sharp, D. \& Muir, F. (1912) The comparative anatomy of the male genital tube in Coleoptera. Transactions of the Entomological Society of London, 1912(3), 477-642, plates XLII-LXXVIII.

Smetana, A. (1971) Revision of the tribe Quediini of America North of Mexico (Coleoptera: Staphylinidae). Memoirs of the Entomological Society of Canada, 79, vi +303 pp.

Snodgrass, R.E. (1936) Morphology of the insect abdomen. Part III. The male genitalia (including arthropods other than insects). Smithsonian Miscellaneous Collections, 95(14), 1-96.

Thomson, C.G. (1858) Försök till uppställning af Sveriges Staphyliner. Öfversigt af Kongl. Vetenskaps-Akademiens Förkhandlingar, 15, 27-40. 